Article

\title{
Mineralogy and Geochemistry of the No. $5^{-2}$ High-Sulfur Coal from the Dongpo Mine, Weibei Coalfield, Shaanxi, North China, with Emphasis on Anomalies of Gallium and Lithium
}

\author{
Guohong Qin $₫$, Daiyong Cao*, Yingchun Wei, Anmin Wang and Jincheng Liu \\ College of Geoscience and Surveying Engineering, China University of Mining and Technology (Beijing), \\ Beijing 10083, China \\ * Correspondence: cdy@cumtb.edu.cn
}

Received: 27 May 2019; Accepted: 28 June 2019; Published: 30 June 2019

\begin{abstract}
This paper reports the mineral compositions and geochemical characteristics of the No. $5^{-2}$ high-sulfur coal (Taiyuan Formation) from Dongpo Mine, Weibei Coalfield, Shaanxi, Northern China via transmitted and reflected light microscopy, scanning electron microscope equipped with an energy-dispersive $\mathrm{X}$-ray spectrometer (SEM-EDS), $\mathrm{X}$-ray diffraction (XRD), inductively coupled plasma mass spectrometry (ICP-MS), and X-ray fluorescence spectrometry (XRF). We also confirmed the input of intermediate-felsic volcanic ashes into the Taiyuan Formation coals in Dongpo Mine, Weibei Coalfield. The results show that Dongpo coals are enriched in $\mathrm{Ga}$ and $\mathrm{Li}$ compared to the average values for world hard coals, and they are depleted in $\mathrm{Al}_{2} \mathrm{O}_{3}$ compared to Chinese coals. The coal low temperature ash contains kaolinite, illite, quartz, calcite, pyrite, and to a lesser extent, chlorite, plagioclase, dolomite, ankerite, and apatite. The concentration anomalies of $\mathrm{Ga}$ and $\mathrm{Li}$ in No. $5^{-2}$ high-sulfur coal were not caused by the Benxi Formation Bauxite, but by the influence of multiple geological factors. The Middle Proterozoic moyite from the Yinshan Oldland led to the slightly higher Ga and Li contents of the No. $5^{-2}$ coal than those in world hard coals. Input of synchronization volcanic ash, injection of hydrothermal fluids during the syngenetic or early diagenetic stages and influence of seawater further contributed to the Ga and Li enrichment of the No. $5^{-2}$ coal.
\end{abstract}

Keywords: coal; high sulfur; gallium; lithium; anomalies; mineralogy; origin; volcanic ash

\section{Introduction}

Trace elements in coals, e.g., Ga, Ge, Li, rare earth elements and Y (REY, or REE if $Y$ is not included), $\mathrm{Sc}, \mathrm{Re}, \mathrm{Zr}, \mathrm{Hf}, \mathrm{Nb}$, and Ta have attracted a great deal of attention in recent years [1-15], because the concentrations of these elements in coals or in coal ashes are equal to or higher than those found in conventional rare metal deposits and because of the worldwide demand for these rare metals, especially $\mathrm{Li}, \mathrm{Ga}$, and REY [16]. Previous studies have shown that the No. 6 coal (Taiyuan Formation) from the Junger Coalfield, northeastern Ordos Basin, north China, is highly enriched in $\mathrm{Al}, \mathrm{Ga}$, Li, and REY, and thus, this coal is considered to be a coal-hosted $\mathrm{Al}(\mathrm{Ga}, \mathrm{Li}, \mathrm{REY})$ ore deposit $[8,9,17-20]$. In addition to the Middle Proterozoic moyite of the Yinshan Oldland region, the neighboring weathered and oxidized bauxite of the Benxi Formation (Pennsylvanian) played a dominant role in the enrichment of these elements, especially Ga $[17,19,20]$.

Deposits formed by volcanic ash occur in many coal seams and coal-bearing sequences around the world [21,22]. In China, the influence of volcanic ash on the trace element contents of coals from southwestern China have been investigated [23]. For example, the $\mathrm{Fe}, \mathrm{Cu}, \mathrm{U}, \mathrm{Mo}$, and $\mathrm{Zr}$ 
contents of the coal from the Zhijin Coalfield, Guizhou, are attributed to synsedimentary volcanic ash [24,25]. Similar volcanic-influenced material has also been found in the No. 6 coal from the Qinglong Coalfield in western Guizhou [26]. The high Be, Ti, Ga, Zr, Nb, Hf, Ta, W, Th, and REY concentrations of the No. 11 coal from the Songzao Coalfield, Chongqing, were caused by alkali volcanic ashes deposited in the swamp during peat accumulation [27]. Dai et al. [28] describes a new type of $\mathrm{Nb}$ (Ta)-Zr(Hf)-REE-Ga rare-metal deposit of volcanic origin in the Late Permian coal-bearing strata in eastern Yunnan, southwestern China. Recently, the mechanism by which the volcanic ash causes the element enrichment has been studied in more detail. Zhao et al. [29] pointed out that the $\mathrm{Nb}-Z r-R E E-G a$ mineralization in southwestern China was caused by the interaction with alkaline volcanic ashes and the subsequent percolation of low-temperature fluids. Dai et al. [30] further proposed that these volcanic ashes originated from alkaline magmatism, which was followed by a continuous hydrothermal-weathering process. The hydrothermal solutions were sourced from acidic rains mixed with the $\mathrm{CO}_{2}$ produced by the degassing of the Emeishan plume. Nechaev et al. [31] concluded that the major factors controlling the REY mineralization in South Primorye (Russian Far East) were meteoric water and $\mathrm{CO}_{2}$ from a mantle origin. However, the element enrichments caused by the volcanic ash in northern China have rarely been investigated.

The Ordos Basin contains the second largest coal reserves in China [17]. Previous studies [32] have shown that volcanic materials most commonly occur in the Late Palaeozoic sandstone in the southern Ordos Basin. The wide distribution of volcanic materials suggests the frequent and intense volcanic activity in the Late Palaeozoic of the southern Ordos Basin. However, the type of volcanic ash input and whether the coal benches were influenced by the volcanic ash remains to be determined. Further identification of the volcanic ash in the southern Ordos Basin is of sedimentologic and geochronologic significance.

In this study, a new area with Ga-Li enriched high-sulfur coals, i.e., the No. $5^{-2}$ coal in Dongpo Mine, is investigated. In addition, based on the analysis of the mineralogical composition and geochemical characteristics of several samples collected from this mine, we attempt to address the following questions: (1) Does the Benxi Formation bauxite play a dominant role in the enrichment of $\mathrm{Ga}$ and $\mathrm{Li}$ in the southeastern Ordos Basin, as it does in the northern Ordos Basin? (2) Was there an input of volcanic ash into the Pennsylvanian Taiyuan Formation coal from Dongpo Mine, southeastern Ordos Basin, and if there was, what types of volcanic ash were involved?

\section{Geologic Setting}

Dongpo Mine is located in the eastern part of the Tongchuan mining district, Weibei Coalfield, southeastern Ordos Basin, northern China (Figure 1A,B). The total area of this mine is $32.35 \mathrm{~km}^{2}$, and the recoverable coal reserve is $4.3 \times 10^{7} \mathrm{t}$. The folds and faults in the Tongchuan mining district are well developed, especially the deep fractures [33]. The sedimentary sequences in the mine include the Ordovician, Pennsylvanian Taiyuan Formation; the Early Permian Shaanxi and Lower Shihezi Formations; the Late Permian Upper Shihezi Formation; and Neogene and Quaternary deposits [34] (Figure 2A).

The coal-bearing stratum is found in the Taiyan Formation, which unconformably overlies the Ordovician limestone and conformably underlies the Shaanxi Formation. The Taiyuan Formation, which is 6.51-63.49 m thick, is mainly composed of mudstone, coal, medium-grained sandstone and carbonaceous mudstone. There are four coal seams, the No. 10, No. 6, No. $5^{-2}$, and No. $5^{-1}$ coals from bottom to top, which were originally deposited in tidal flat environments [33]. The No. $5^{-2}$ coal is the only locally recoverable coal seam and has a thickness of 0.86-m to 6.89-m thick (average of $2.29 \mathrm{~m}$ ), and mainly include meager-lean coal and coking coal [34]. 


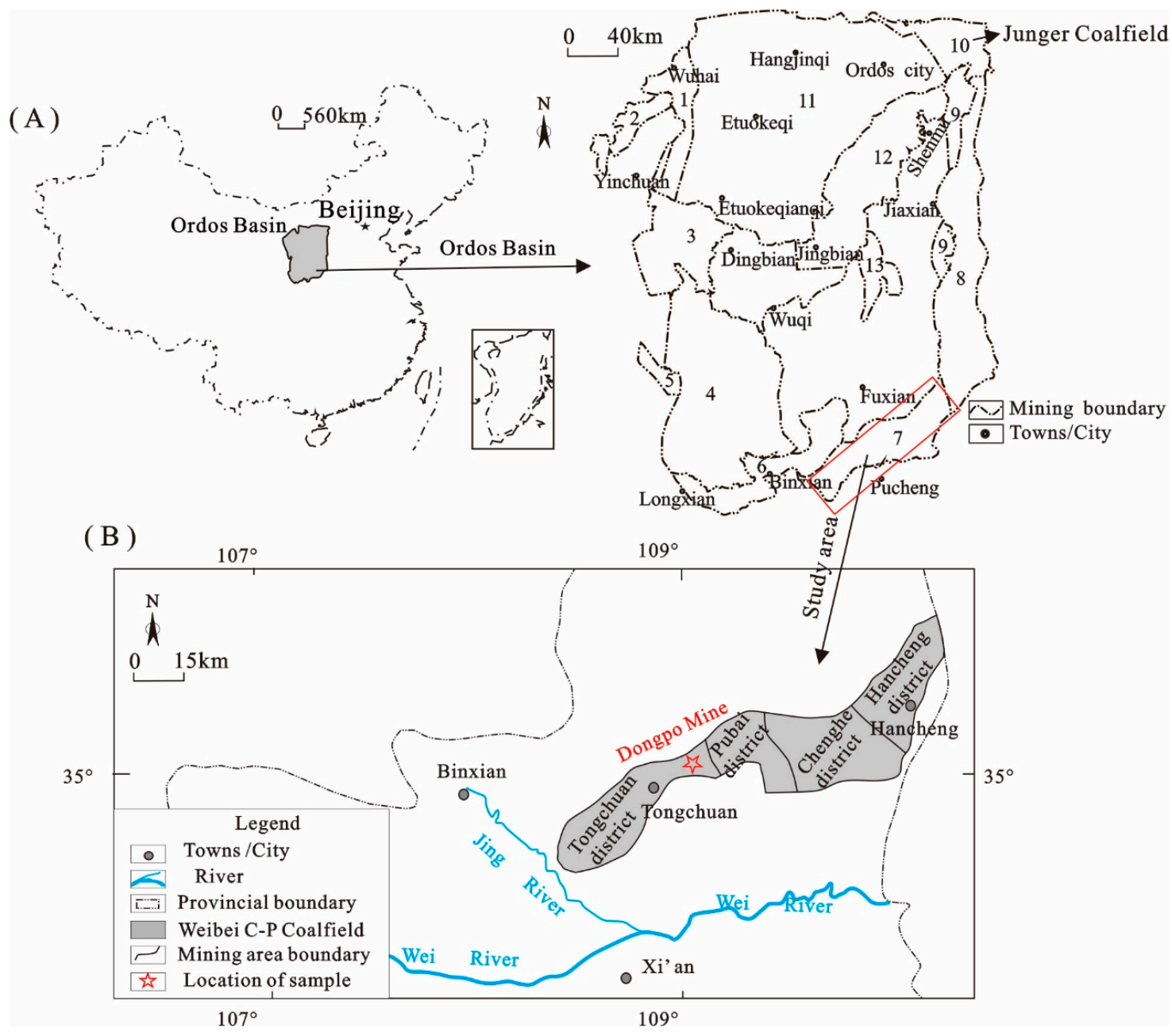

Figure 1. Locations of the (A) Ordos Basin and (B) Dongpo Mine modified after [35]. 1-Zhuozishan coalfield, 2-Helanshan coalfield, 3-Ningdong coalfield, 4-Longdong coalfield, 5-Ningnan coalfield, 6-Huanglong coalfield, 7-Weibei coalfield, 8-Hedong coalfield, 9-Shanbei Permo-Carboniferous coalfield, 10-Junger coalfield, 11-Dongsheng coalfield, 12-Shanbei Jurassic coalfield, 13-Shanbei Triassic coalfield. 
(A) Sedimentary Thickness Coalseam

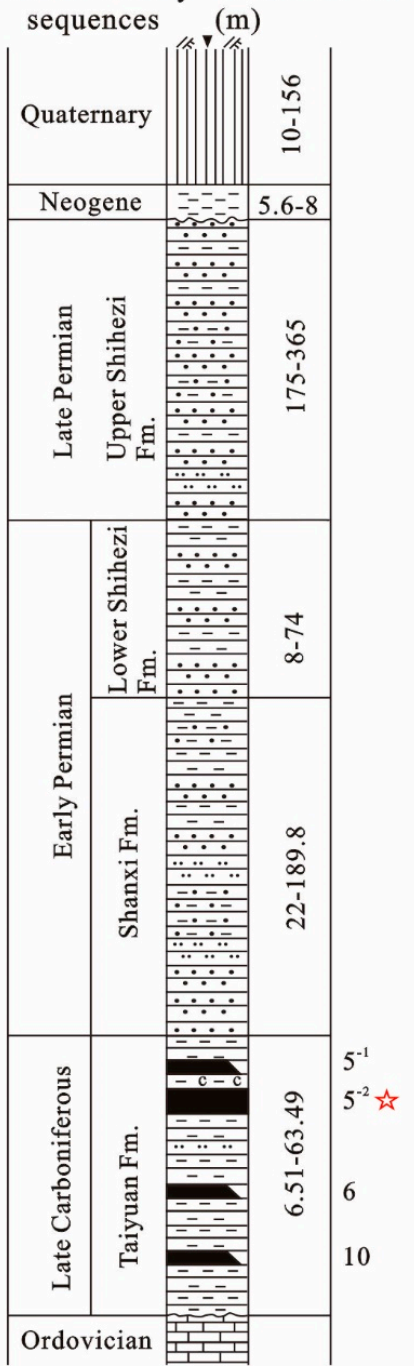

(B) $(\mathrm{cm})$ Sample section

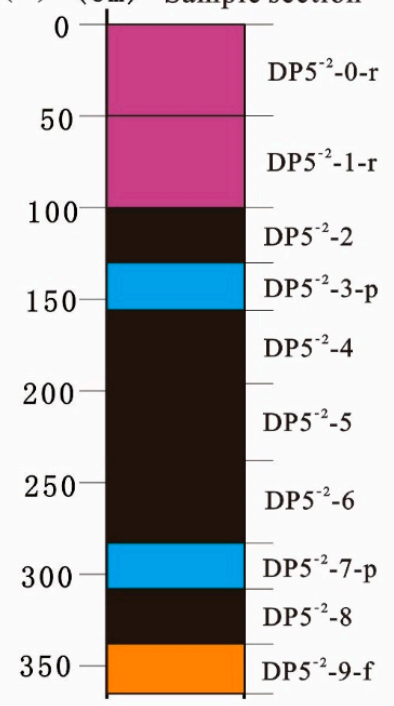

Legend for (A) Legend for (B)

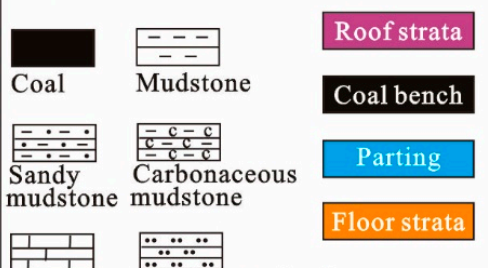

Limestone Medium-grained

$\because \because$

Coarse-grained

sandstone

is

Sampling coal seam

Figure 2. (A) Sedimentary sequences and (B) the vertical sampled section of the No. $5^{-2}$ coal from Dongpo Mine.

\section{Samples and Analytical Methods}

\subsection{Sample Collection}

A total of ten samples of the No. $5^{-2}$ coal, including five coal benches, two partings, two roofs, and one floor, were collected from an underground working face in Dongpo Mine, Weibei Coalfield, following the Chinese Standard Method GB/T482-2008 [36]. From top to bottom, the five coal bench samples, the two partings (with a suffix-p), the two roofs (with a suffix-r), and a floor (with a suffix-f) are identified as DP5 ${ }^{-2}-0$ to DP5 ${ }^{-2}-9$ (Figure 2B). Each coal bench sample was cut over an area of $10-\mathrm{cm}$ wide, and 10-cm deep. All of the samples were fresh, and after collection, they were immediately stored in plastic bags to minimize contamination and oxidation.

\subsection{Analytical Methods}

According to the American Society for Testing and Materials (ASTM) standards D3173-11 (2011); D3174-11 (2011), and D3175-11 (2011) [37-39] respectively, proximate analysis was done, which include the determination of moisture $\left(\mathrm{M}_{\mathrm{ad}}\right)$, volatile matter $\left(\mathrm{V}_{\mathrm{daf}}\right)$, and ash yield $\left(\mathrm{A}_{\mathrm{d}}\right)$. The total sulfur and forms of sulfur were determined and calculated in accordance with the ASTM standards D3177-02 (2007) and D2492-02 (2012) [40,41], respectively. The petrographic analysis of the coals was made on the 
same polished surfaces of samples using a DM4500P reflected light microscope under oil immersion at China University of Mining and Technology, Beijing (CUMTB). The maceral composition and the vitrinite random reflectance were determined according to Pickel et al. [42], the ICCP System 1994 (ICCP, 1998, 2001) [43,44] and ASTM Standard D2798-11a (2011) [45], respectively.

Thin sections of the samples were made at the Société Générale de Surveillance S.A-China Stand Science and Technology Group Corporation (SGS-CSTC) Standards Technology Service Corporation and were studied using a transmitted light optical microscope to identify the mineral compositions [46] at the China University of Mining and Technology, Beijing (CUMTB).

Mineral phases of the low temperature ash (LTA) samples of coals, the partings and host rock samples were determined by means of powder X-ray diffraction (XRD). Low-temperature ashing of the powdered coal samples was carried out using an EMITECH K1050X plasma asher (Ouorum, Ashford, UK) prior to XRD analysis. XRD analysis was performed using a D/max-2500/PC powder diffractometer (Rigaku, Tokyo, Japan) with Ni-filtered $\mathrm{Cu}-\mathrm{K} \alpha$ radiation and a scintillation detector. The XRD pattern was recorded over a $2 \theta$ interval of $2.6^{\circ}-45^{\circ}$ for whole rock analysis and $2.6^{\circ}-30^{\circ}$ for clay minerals, with a step size of $0.02^{\circ}$. Semiquantitative XRD estimation of the mineral contents was obtained by using the Reference Internal Standard Method [47].

A field emission-scanning electron microscope (FE-SEM, ZEISS Merlin Compact, Oberkochen, Germany), in conjunction with an Energy Dispersive X-Ray Spectroscopy (EDAX) energy-dispersive X-ray spectrometer (Bruker Nano Xflash 6/100, Karlsruhe, Germany), was used to study the minerals in coal and rock samples at Peking University. Samples were made into pellets, polished by Argon ion polishing machine (Leica, EM RES102, Heidelberg, Germany), coated with gold using a Quorum Q150T ES sputtering coater, and then mounted on standard aluminum SEM stubs using sticky electron-conductive carbon tabs. The working distance of the FE-SEM-EDS was 8-9.9 mm, beam voltage $15.0 \mathrm{kV}$, aperture $60 \mathrm{um}$, and back-scattered electron detector was used to acquire BSE images. In addition, images captured under secondary electron mode (SE) by a field emission scanning electron microscope (Hitachi model S-4800, HITACHI, Tokyo, Japan) with an energy dispersive X-ray spectrometer (EDS) were conducted at Beijing Center for Physical and Chemical Analysis (BCPCA). Small grains of crushed coal, with a smooth and fresh section, were coated with gold using a Quorum Q150T ES sputtering coater, and then mounted on standard aluminum SEM stubs using sticky electron-conductive carbon tabs. The working distance of the FE-SEM-EDS was $14 \mathrm{~mm}$, beam voltage $15.0 \mathrm{kV}$, aperture $10 \mu \mathrm{m}$.

To further confirm the existence of apatite and to more accurately describe the morphology of the apatite crystals, the separation of single apatite grains was conducted at the Langfang Yuheng Rock Ore Technology Service Corporation. After crushing the samples into 0.15-0.13 mm coal block samples, shaking bed separation was carried out to remove the light minerals. After magnetic separation, flotation, electromagnetic separation, manual cleaning, separation using a heavy solution of tribromethane, high frequency dielectric separation, and heavy liquid separation using diiodomethane, 98-99\% pure apatite was obtained by flotation. Then, other minerals were picked out using a reflected light microscope (BX51, OLYMPUS, Tokyo, Japan). The morphology of the apatite crystals was observed using a reflected light microscope (OLYMPUS, BX51).

Samples for geochemical analysis were crushed and ground to less than 200 mesh size using a tungsten carbide ball mill. The percentages of major oxides $\left(\mathrm{SiO}_{2}, \mathrm{TiO}_{2}, \mathrm{Al}_{2} \mathrm{O}_{3}, \mathrm{Fe}_{2} \mathrm{O}_{3}, \mathrm{MgO}, \mathrm{CaO}\right.$, $\mathrm{MnO}, \mathrm{Na}_{2} \mathrm{O}, \mathrm{K}_{2} \mathrm{O}$, and $\mathrm{P}_{2} \mathrm{O}_{5}$ ) for each sample after ashing at $815{ }^{\circ} \mathrm{C}$ were determined by $\mathrm{X}$-ray fluorescence spectrometer (XRF; PANalytical Axios, Malvern Panalytical, Almelo, The Netherland). The loss on ignition (LOI) was also determined at this temperature $\left(815^{\circ} \mathrm{C}\right)$ by gravimetric method. The samples for XRF analysis were prepared by borate fusion in an automated fusion furnace (CLAISSE TheOX). Each sample (0.7 g) was mixed and homogenized with lithium borate flux (7 g; CLAISSE, pure, $\left.67 \% \mathrm{Li}_{2} \mathrm{~B}_{4} \mathrm{O}_{7}+33 \% \mathrm{LiBO}_{2}\right)$. The trace elements of the samples were determined by inductively coupled plasma mass spectrometry (ICP-MS, ELEMENT XR). For ICP-MS analysis, samples were digested by using an UltraClave Microwave High Pressure Reactor (Milestone, Milan, Italy). Multi-element 
standards (Inorganic Ventures: CCS-1, CCS-4, CCS-5, and CCS-6; GBW07103, GBW07104) were used for calibration of trace element concentrations. More details for these coal-related sample digestion and ICP-MS analysis techniques are given by Dai et al. [48]. Due to the contamination of the Tungsten Carbide mill, W was not studied in this paper.

\section{Results}

\subsection{Coal Chemistry and Petrology}

The proximate analysis, total sulfur, forms of sulfur, and vitrinite reflectance results for the No.5 coal from Dongpo Mine are presented in Table 1 . The vitrinite reflectance $(1.42 \%$ on average) and the weighted average volatile matter contents $(21.27 \%$, dry and ash-free basis) of the coal bench samples indicate a low volatile bituminous coal according to the ASTM classification (ASTM D388-12, 2012) [49]. In addition, the coal is characterized by a low-ash content (18.92\% on average) and a high-sulfur content (3.55\% on average) according to Chinese Standards GB15224.1-2010 [50] (coals with an ash yield of $>10 \%$, but $\leq 20 \%$ are low ash coals) and GB15224.2-2010 [51] (coals with a total sulfur content of $>3 \%$ are high-sulfur coals). The total sulfur contents of the No. $5^{-2}$ coal gradually increases from bottom to top, and the corresponding main form of sulfur in the coal gradually changes from organic sulfur to pyritic sulfur (Table 1).

Table 1. Coal bench thickness (cm), proximate analysis (\%), sulfur (\%), and random vitrinite reflectance (\%) of the No. $5^{-2}$ coal from Dongpo Mine.

\begin{tabular}{cccccccccc}
\hline Samples & Thickness & $\mathbf{M}_{\mathbf{a d}}$ & $\mathbf{A}_{\mathbf{d}}$ & $\mathbf{V}_{\mathbf{d a f}}$ & $\mathbf{S}_{\mathbf{t}, \mathbf{d}}$ & $\mathbf{S}_{\mathbf{s}, \mathbf{d}}$ & $\mathbf{S}_{\mathbf{p}, \mathbf{d}}$ & $\mathbf{S}_{\mathbf{o}, \mathbf{d}}$ & $\mathbf{R r}$ \\
\hline DP5 $^{-2}-2$ & 30 & 0.29 & 18.61 & 21.74 & 4.85 & 0.01 & 3.87 & 0.97 & 1.42 \\
DP5 $^{-2}-4$ & 40 & 0.29 & 19.54 & 21.95 & 4.12 & 0.01 & 2.23 & 1.88 & 1.41 \\
DP5 $^{-2}-5$ & 42 & 0.3 & 20.95 & 24.44 & 3.47 & 0.01 & 2.06 & 1.34 & 1.4 \\
DP5 $^{-2}-6$ & 45 & 0.31 & 19.37 & 19.18 & 3.41 & 0 & 1.24 & 2.17 & 1.43 \\
DP5 $^{-2}-8$ & 30 & 0.3 & 14.87 & 18.59 & 1.84 & 0 & 0.56 & 1.28 & 1.47 \\
WA & & 0.299 & 18.92 & 21.27 & 3.55 & 0.006 & 1.949 & 1.586 & 1.42 \\
\hline
\end{tabular}

$M$, moisture; $A$, ash yield; $V$, volatile matter; $S_{t}$, total sulfur; $S_{s}$, sulfate sulfur; $S_{p}$, pyritic sulfur; $S_{o}$, organic sulfur; $d$, dry basis; daf, dry ash-free basis; ad, as-determined basis; $R r$, random vitrinite reflectance; WA, weighted average based on thickness of sample interval.

Compared to the No.6 coal (Taiyuan Formation) in the Junger Coalfield reported by Dai et al. [17,19], e.g., the Heidaigou and Haerwusu coals with random vitrinite reflectances of $0.58 \%$ and $0.57 \%$, the Dongpo coals in this study have lower volatile matter contents $(21.27 \%$ on average, dry and ash free basis) and higher random vitrinite reflectance (1.42\% on average). The differences in the degree of metamorphism of these coals is mainly related to the regional magmatic thermal metamorphism occurred in Dongpo Mine [52]. According to Yang et al. [52], the Qinling fold in the southern part of the Weibei Coalfield has a large range of acid magma intrusions during the Indo-Chinese epoch period. The magma intrusions formed some thermal anomaly zones, which baked the low-rank coal at a higher temperature. The low-rank coal had been subjected to deep metamorphism before the stable period in these zones. Due to the mesogenetic regional telemagmatic metamorphism of coal, the metamorphism degree of Taiyuan Formation coal in Weibei Coalfield was elevated and is obviously higher than that in Junger Coalfield, with random vitrinite reflectance up to $1.42 \%$.

The total proportion of the vitrinite-group macerals $\left(79.6 \%\right.$ on average, mineral-free) in the No. $5^{-2}$ coal is much higher than that of the inertinite-group (20.4\% on average, mineral-free; Table 2$)$. Liptinite was not observed, since it is difficult to distinguish liptinites in low volatile bituminous coals. This is quite different from the relative proportions found in the No. 6 coal from the Junger Coalfield, and from those found in other Late Paleozoic coals in the northern part of North China, both of which usually have slightly higher proportions of inertinite than vitrinite [20,53]. 
Table 2. The maceral contents of the coal samples from Dongpo Mine determined using optical microscopy (Vol. \%; on a mineral-free basis).

\begin{tabular}{cccccccccccc}
\hline Samples & Thickness & $\mathbf{T}$ & $\mathbf{C T}$ & $\mathbf{C D}$ & $\mathbf{T}-\mathbf{V}$ & $\mathbf{F}$ & $\mathbf{S F}$ & Mic & Mac & Fun & T-I \\
\hline DP5 $^{-2}-2$ & 30 & 3.6 & 39.8 & 31.1 & 74.5 & 2.0 & 6.0 & 15.7 & 1.2 & 0.6 & 25.5 \\
DP5 $^{-2}-4$ & 40 & 2.6 & 41.0 & 32.6 & 76.1 & 0.6 & 7.3 & 14.9 & 1.0 & 0.1 & 23.9 \\
DP5 $^{-2}-5$ & 42 & 1.7 & 43.4 & 39.8 & 84.9 & 0.9 & 5.1 & 7.7 & 1.5 & 0.0 & 15.1 \\
DP5 $^{-2}-6$ & 45 & 1.4 & 42.5 & 37.2 & 81.1 & 0.8 & 7.3 & 9.6 & 1.3 & 0.0 & 18.9 \\
DP5 $^{-2}-8$ & 30 & 2.0 & 40.5 & 36.9 & 79.5 & 0.9 & 7.7 & 10.8 & 1.1 & 0.0 & 20.5 \\
WA & & 2.2 & 41.6 & 35.8 & 79.6 & 1.0 & 6.7 & 11.5 & 1.2 & 0.1 & 20.4 \\
\hline
\end{tabular}

$\mathrm{T}$, telinite; $\mathrm{CT}$, collotelinite; $\mathrm{CD}$, collodetrinite; $\mathrm{T}-\mathrm{V}$, total vitrinite; $\mathrm{F}$, fusinite; $\mathrm{SF}$, semifusinite; Mic, micrinite; Mac, macrinite; Fun, funginite; T-I, total inertinite. WA, weighted average based on thickness of sample interval.

The vitrinite in the No. $5^{-2}$ coal is dominated by collotelinite (41.6\% on average, mineral-free) and collodetrinite ( $35.8 \%$ on average, mineral-free), with trace amounts of telinite ( $2.2 \%$ on average, mineral-free). The collodetrinite contains fracture-filling calcite (Figure 3A) and the matrix contains embedded-clay minerals and pyrite (Figure 3B).
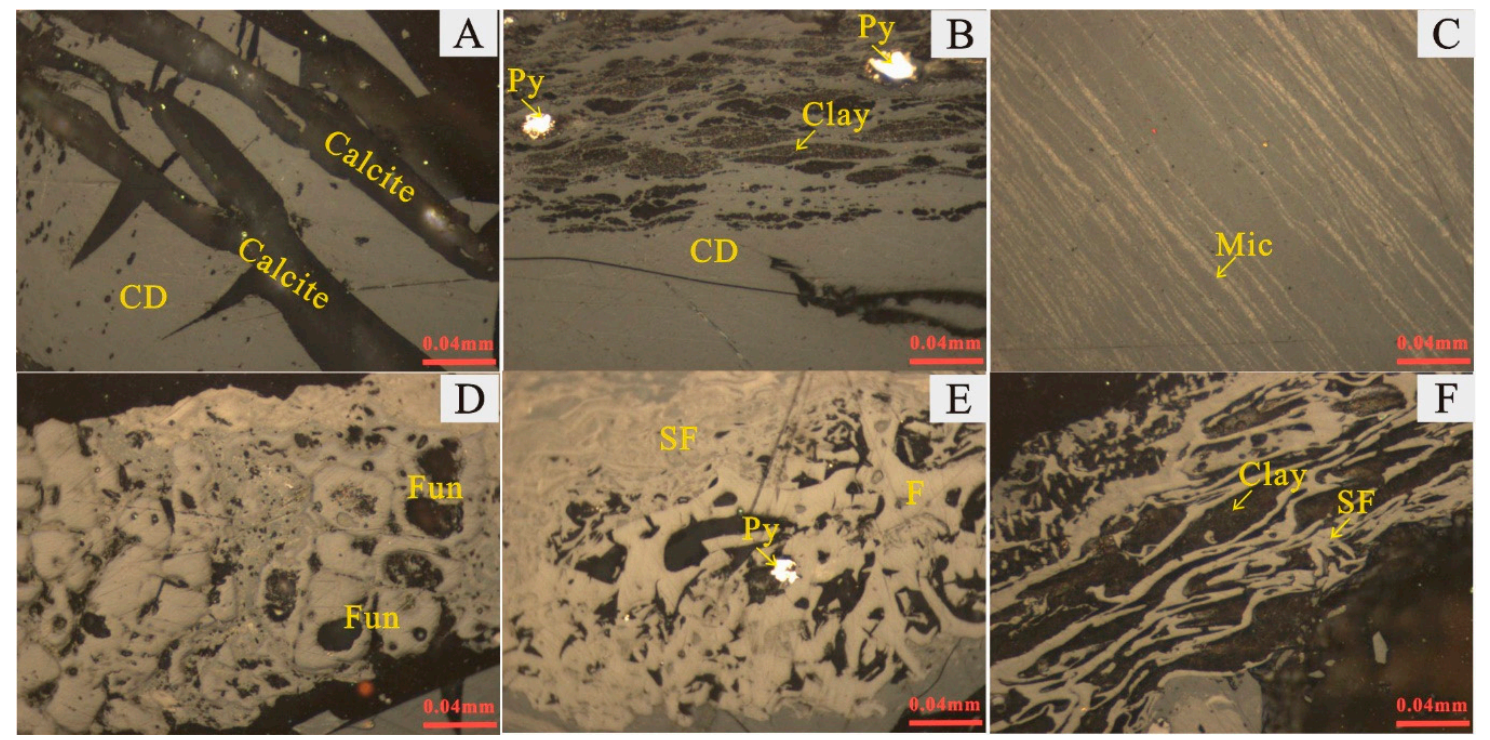

Figure 3. Vitrinite and inertinite in the coals from Dongpo Mine. Reflected light, oil immersion. (A) Calcite filled fractures in the collodetrinite in sample DP5 $5^{-2}-5$, (B) Collodetrinite with cell-filling clay minerals and pyrite in sample DP5 $5^{-2}-6$, (C) Micrinite in sample DP5 $5^{-2}-2$, (D) Funginite in sample $\mathrm{DP5}^{-2}-2$, (E) Fusinite, semifusinite and pyrite in sample DP5 ${ }^{-2}-5$, (F) Semifusinite with cell-filling clay minerals in DP5 ${ }^{-2}-8$. CD, Collodetrinite; Py, Pyrite; Mic, Micrinite; Fun, Funginite; SF, Semifusinite; F, Fusinite; Clay, Clay minerals.

The inertinite in the No. $5^{-2}$ coal is mainly composed of micrinite (Figure $3 C ; 11.5 \%$ on average, mineral-free) and, to a lesser extent, semifusinite ( $6.7 \%$ on average, mineral-free), with small amounts of macrinite, fusinite and funginite (Figure 3D). In most cases, the cell structures of the semifusinite and fusinite are not well-preserved and have a swelled and degraded form (Figure 3E), which is sometimes filled by clay minerals and pyrite (Figure 3E,F).

\subsection{Minerals and Their Modes of Occurrence}

The semi-quantitative proportions of each crystalline phase detected by XRD from the No. $5^{-2}$ coal LTAs, partings, and host rocks are given in Table 3. The mineral compositions of the coal low temperature ash mainly include kaolinite ( $25.18 \%$ to $69.31 \%)$, calcite $(1.4 \%$ to $50.5 \%)$, pyrite $(2.1 \%$ to $27.9 \%)$, quartz ( $2.8 \%$ to $14 \%$ ), illite $(0.51 \%$ to $9.93 \%)$, and, to a lesser extent, chlorite $(4.67 \%$, only occurred 
in sample DP5 $\left.{ }^{-2}-2\right)$, plagioclase ( $1 \%$ to $1.8 \%$, not detected in samples $\mathrm{DP}^{-2}-4$ and $\left.\mathrm{DP}^{-2}-8\right)$, dolomite $\left(0.6 \%\right.$ to $11.7 \%$, not detected in samples DP5 ${ }^{-2}-4$ and DP5 $\left.{ }^{-2}-6\right)$, ankerite $(6 \%$, mainly occurred in sample DP5 $\left.{ }^{-2}-6\right)$, and apatite (1.4\% in sample DP5 ${ }^{-2}-5$ and $4.4 \%$ in sample DP5 $\left.{ }^{-2}-8\right)$. Some dolomite and ankerite were detected in DP5 ${ }^{-2}-4$ by SEM-EDS, but below the detection limit of the XRD technique. The mineral phases in the partings and host rocks are dominantly kaolinite, and to a lesser extent, quartz, illite, and illite/smectite (I/S), with smaller proportions of K-feldspar, plagioclase, dolomite, pyrite, and calcite (Table 3). Additionally, traces of svanbergite $\left(\mathrm{SrAl}_{3}\left(\mathrm{PO}_{4}\right)\left(\mathrm{SO}_{4}\right)(\mathrm{OH})_{6}\right)$, goyazite $\left(\mathrm{SrAl}_{3}\left(\mathrm{PO}_{4}\right)_{2}(\mathrm{OH})_{5} \cdot \mathrm{H}_{2} \mathrm{O}\right)$, albite $\left(\mathrm{NaAlSi}_{3} \mathrm{O}_{8}\right)$, and chalcopyrite $\left(\mathrm{CuFeS}_{2}\right)$ were identified in the coal and Ti-kaolinite, zircon $\left(\mathrm{ZrSiO}_{4}\right)$, and anatase/rutile $\left(\mathrm{TiO}_{2}\right)$ were identified in the partings by SEM-EDS. Diaspore $\left(\mathrm{Al}_{2} \mathrm{O}_{3} \cdot \mathrm{H}_{2} \mathrm{O}\right)$ and boehmite $(\mathrm{Al} \cdot \mathrm{O} \cdot \mathrm{OH})$, which are highly enriched in the No. 6 coal in the Junger Coalfield $[17,19,20]$, were not observed in the Dongpo Mine samples.

Table 3. Low temperature ash yields (LTA, \%) and mineral compositions (\%) of the LTA samples, partings, roof, and floor samples from XRD analysis.

\begin{tabular}{|c|c|c|c|c|c|c|c|c|c|c|c|c|c|}
\hline Sample & LTA & Qtz & Kao & Illi & Chl & $\mathrm{I} / \mathrm{S}$ & K-Fel & Pla & Cal & Dol & Ank & Py & Apa \\
\hline $\mathrm{DP} 5^{-2}-0-\mathrm{r}$ & & 18.5 & 47.34 & 11.56 & & 13.5 & 1.1 & 1.9 & & 0.8 & & 5.3 & \\
\hline $\mathrm{DP} 5^{-2}-1-\mathrm{r}$ & & 15.9 & 43.62 & 12.78 & & 18.8 & 0.8 & 2.2 & & 1.5 & & 4.4 & \\
\hline $\mathrm{DP}^{-2}-2$ & 22.13 & 8.2 & 43.8 & 9.93 & 4.67 & & & 1.8 & 3.1 & 0.6 & & 27.9 & \\
\hline $\mathrm{DP}^{-2}-3-\mathrm{p}$ & & 6.9 & 77.26 & 13.64 & & & 0.4 & 1.1 & & & & 0.7 & \\
\hline $\mathrm{DP} 5^{-2}-4$ & 23.77 & 4.5 & 50.19 & 0.51 & & & & & 41.8 & & & 3 & \\
\hline $\mathrm{DP}^{-2}-5$ & 28.75 & 2.9 & 25.18 & 1.32 & & & & 1 & 50.5 & 11.7 & & 6 & 1.4 \\
\hline $\mathrm{DP}^{-2}-6$ & 23.91 & 14 & 69.31 & 2.89 & & & & 1.1 & 4.6 & & 6 & 2.1 & \\
\hline $\mathrm{DP}^{-2}-7-\mathrm{p}$ & & 6.7 & 82.25 & 5.25 & & & 0.4 & 0.3 & 0.2 & 0.5 & & 4.4 & \\
\hline $\mathrm{DP}^{-2}-8$ & 16.98 & 2.8 & 69.25 & 6.85 & & & & & 1.4 & 0.7 & & 14.6 & 4.4 \\
\hline $\mathrm{DP5}^{-2}-9-\mathrm{f}$ & & 32.7 & 32.29 & 14.67 & & 11.74 & 1 & 2.2 & 1.3 & & & 4.1 & \\
\hline
\end{tabular}

Qtz, Quartz; Kao, Kaolinite; Illi, Illite; Chl, Chlorite; I/S, Illite/Smectite; K-Fel, K-Feldspar; Pla, Plagioclase; Cal, Calcite; Dol, Dolomite; Ank, Ankerite; Py, Pyrite; Apa, Apatite.

The characteristics of the main minerals in the coals, partings, and host rocks are described in detail below.

1. Clay minerals. Kaolinite is the most abundant mineral in the No.5 $5^{-2}$ coal (except in sample DP5 $\left.{ }^{-2}-5\right)$, and it is also the dominant component of most of the roof/floor/parting samples throughout the coal seam. In the coal, most of the kaolinite occurs as cell-fillings (Figure 3B,F, Figure 4A,E,F) and massive lumps (Figure 4B), indicating authigenic and terrigenous origins. In some cases, the kaolinite occurs as vermicular forms (Figure 4C), indicating a volcanic and subsequent in-situ precipitation origin [54]. In a few cases, the kaolinite occurs as fracture-fillings (Figure 6C), indicating an authigenic origin through epigenetic precipitation [54]. By contrast, in the roof/floor/parting samples, kaolinite generally occurs as a matrix (Figure 4D, Figure 7E,F, Figure 11C), and to a lesser extent, it replaces plant tissue (Figure 4D). This type of authigenic kaolinite has also been reported in several tonstein beds $[55,56]$. Additionally, all studied samples contain illite, ranging from $0.51 \%$ to $9.93 \%$ in the coals, $5.25 \%$ to $13.64 \%$ in the partings, and $11.56 \%$ to $14.67 \%$ in the host rocks. Chlorite was detected in sample DP5 ${ }^{-2}-2$, and illite/smectite (I/S) was detected in roof samples by XRD.

2. Silicates. Quartz occurs as fine-grained particles (Figure 5A,B) and as phenocrysts, which are mostly coated by clay minerals, indicating a syngenetic detrital origin. It is worth noting that some of the quartz in sample DP5 ${ }^{-2}-1-r$ has sharp edges rather than rounded edges (Figure 5A). This may be indicative of high temperatures and the influence of volcanic activity [21,24,54,57]. Wang et al. [58] also found high temperature quartz derived from a volcanic source in Wangshiwa Mine, which is close to Dongpo Mine. Additionally, lumpy and dispersed albite (Figure 5C,D and Figure 7C) was observed in $\mathrm{DP}^{-2}$ coal using SEM-EDS. Some of the albite grains were altered and corroded, and some were filled by other minerals, such as goyazite (Figure 5C). 

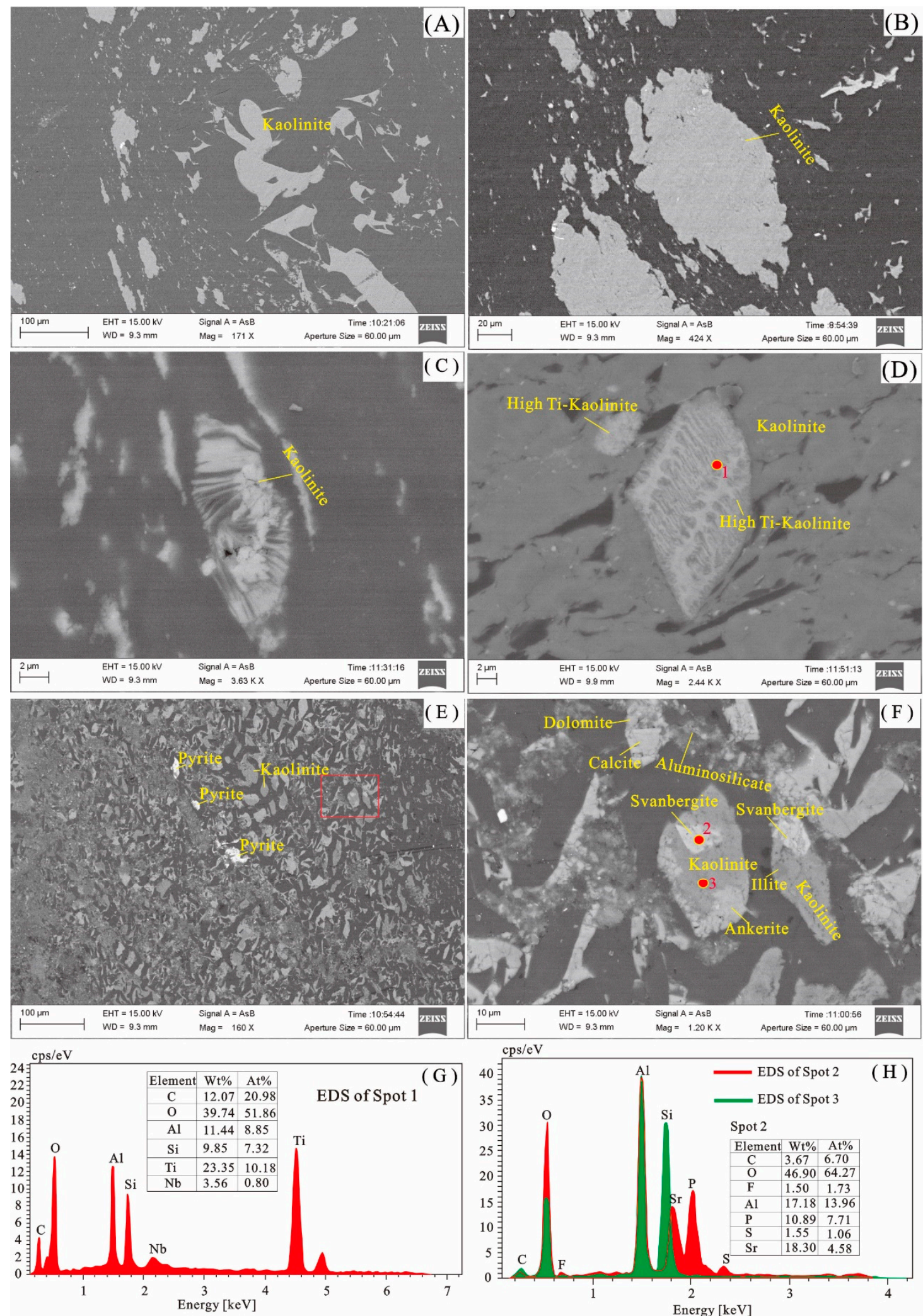

Figure 4. Scanning electron microscope (SEM) backscattered images of the minerals in the samples from Dongpo Mine. (A) Cell-filling kaolinite in sample DP5 $5^{-2}-6$. (B) Lumps of kaolinite in sample DP5 $5^{-2}-8$. (C) Vermicular kaolinite in sample DP5 $5^{-2}$. (D) High-Ti kaolinite re-placing plant tissue in sample DP5 ${ }^{-2}$-3-p. (E) Cell-filling kaolinite and pyrite in sample DP5 ${ }^{-2}-4$. (F) Kaolinite, illite, svanbergite, calcite, ankerite and dolomite in sample DP5 ${ }^{-2}-4$. (G) Energy dispersive X-ray spectrometer (EDS) spectrum of Spot 1. (H) EDS spectrum of Spots 2 and 3. 

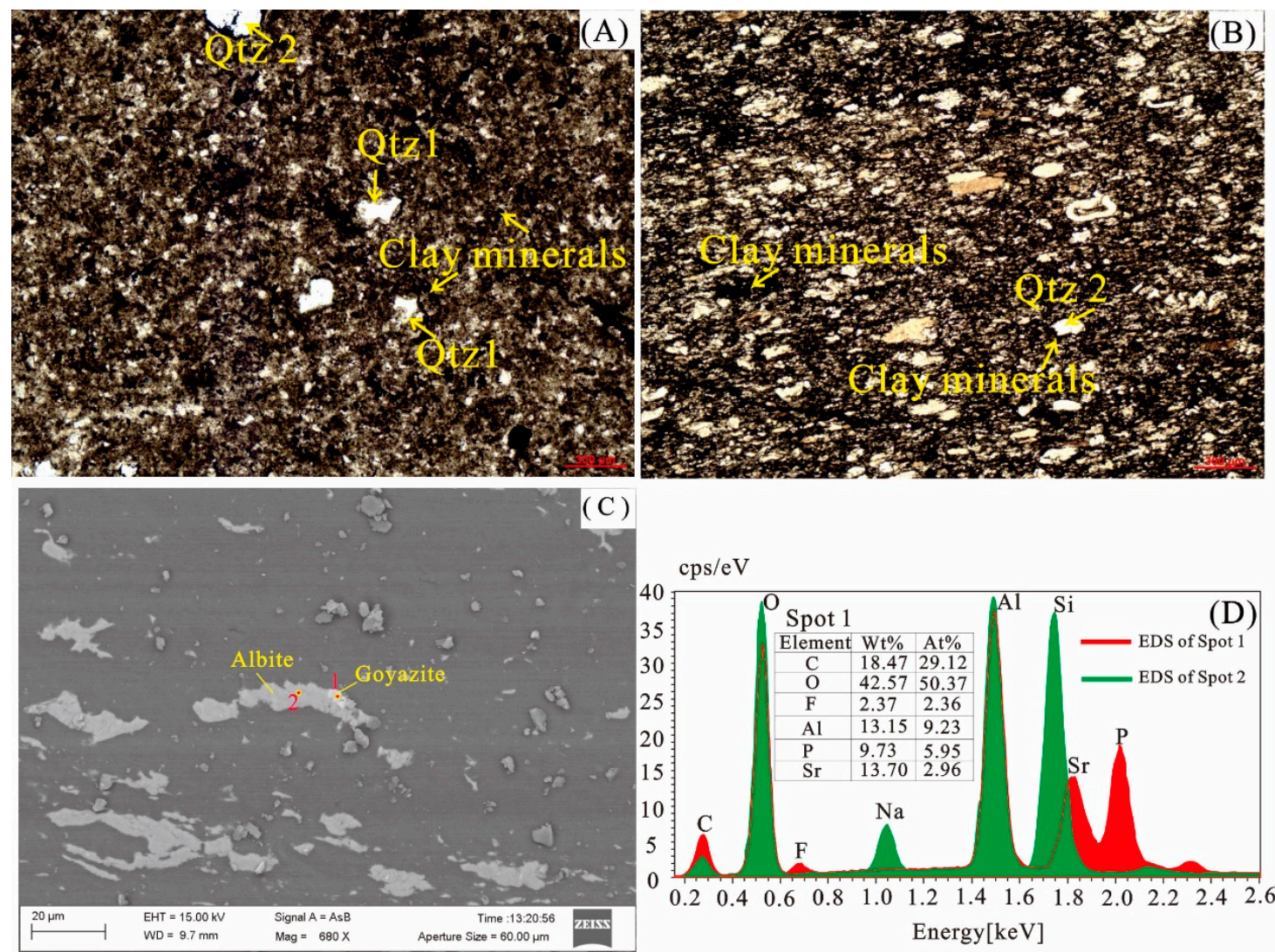

Figure 5. Characteristics of the mineral phases observed using a single-polar microscope $(\mathbf{A}, \mathbf{B})$ and SEM (C,D). (A) Quartz and clay minerals in sample DP5 ${ }^{-2}-1-$ r. (B) Clay minerals and quartz in sample DP5 ${ }^{-2}$-7-p. (C) Albite and goyazite in sample DP5 ${ }^{-2}$-2. (D) EDS spectrum of Spots 1 and 2. Qtz1, angular quartz; and Qtz2, rounded quartz.

3. Carbonate minerals. The carbonate minerals detected in the samples from Dongpo Mine include calcite, ankerite, and dolomite. Calcite is more abundant in samples DP5 ${ }^{-2}-4(41.8 \%)$ and $\mathrm{DP}^{-2}-5$ $(50.5 \%)$ than in the other samples. The calcite generally occurs as fracture-fillings (Figure 3A, Figure 6A-C), and in a few cases, as cell-fillings (Figure 6D). Figure 6A,B shows calcite fracture fillings cutting across the bedding layers of kaolinite. Additionally, the ankerite and dolomite occur as cell- (Figures 4F and 6D) or fracture-fillings (Figure 6E,F), indicating an epigenetic origin.

4. Sulfides. The main sulfide mineral present in the study area is pyrite. Pyrite in the Dongpo coals mainly occurs as pore-fillings (Figure 3B,E) and as discrete crystals (Figure 7A), suggesting an authigenic origin. Most of the euhedral pyrite particles in study area are less than $3 \mu \mathrm{m}$ (Figure 7A). In some cases, disseminated particles of pyrite are widely distributed within the veined calcite (Figure 7B). Small amounts of chalcopyrite were observed using SEM, but were not detected by XRD analysis (Figure 7C,D). Pyrite in the partings generally occurs as massive (Figure 7E) and fracture-fillings (Figure 7F), indicating a syngenetic and epigenetic origin. 

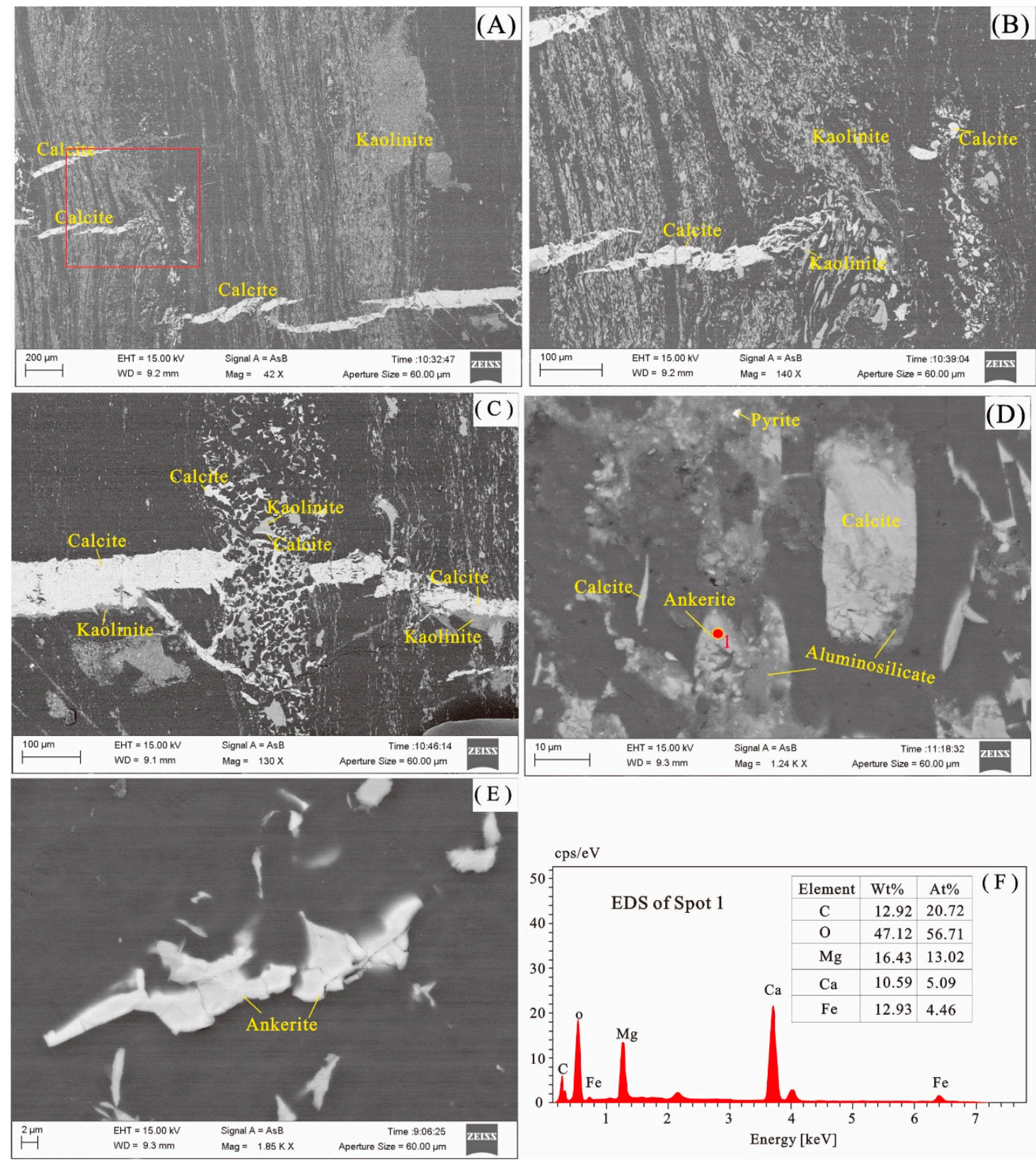

Figure 6. SEM backscattered images of the minerals in the samples from Dongpo Mine. (A) Kaolinite and fracture-filling calcite in sample DP5 ${ }^{-2}-5$. (B), Magnification of the relationship between kaolinite and calcite in the red rectangle in Figure 6A. (C) Calcite and kaolinite in sample DP5 ${ }^{-2}-5$. (D) Calcite, ankerite, pyrite, and aluminosilicate in sample DP5 $5^{-2}$. (E) Fracture-filling ankerite in sample DP5 $5^{-2}-6$.

(F) EDS spectrum of Spot 1.

5. Phosphates. Phosphate minerals, such as apatite $\left(\mathrm{Ca}_{5} \mathrm{~F}\left(\mathrm{PO}_{4}\right)_{3}\right)$, svanbergite $\left(\mathrm{Sr} \mathrm{Al}_{3}\left(\mathrm{PO}_{4}\right)\left(\mathrm{SO}_{4}\right)(\mathrm{OH})_{6}\right)$, and goyazite $\left(\mathrm{SrAl}_{3}\left(\mathrm{PO}_{4}\right)_{2}(\mathrm{OH})_{5} \cdot \mathrm{H}_{2} \mathrm{O}\right)$ were detected in several of the coal samples from Dongpo Mine using XRD and SEM-EDS. Svanbergite and goyazite are intimately associated with other minerals, such as kaolinite (Figure $4 \mathrm{~F}, \mathrm{H}$ ) and albite (Figure 5C,D), and they contain minor amounts of $\mathrm{F}$, i.e., $1.5 \%$ and $2.37 \%$, respectively. Apatite mainly occurs in samples DP5 ${ }^{-2}-5$ and DP5 $5^{-2}-8$ with concentrations of $1.4 \%$ and $4.4 \%$, respectively, detected by XRD (Figures 8 and 9). SEM analysis reveals that the apatite occurs as dispersed particles (Figure 10A,C) and banded composite layers of apatite and aluminosilicate minerals in the coal samples (Figure 10B,D). Additionally, the apatite crystals varies, including light green, yellowish brown, and transparent under reflected light. 
Two forms of apatite crystals were identified in this study: (1) Single rounded apatite crystals (Figure 10E-H,J,K) indicate transportation and a detrital material input from the sediment-source region. (2) Single enhedral and hexagonal apatite crystals (Figure 10E,I-M), indicate a volcanic origin [21]. In some cases, the delicate elongated apatite grains may have fractured as a result of compaction [59] or have been altered [4]. Volcanic debris, shells and/or fecal matter may have acted as the phosphorus source. The apatite probably formed in the pores of the organic matter and in the collodetrinite if $\mathrm{Al}$ was not available to react with the precipitated phosphatic material $[60,61]$.
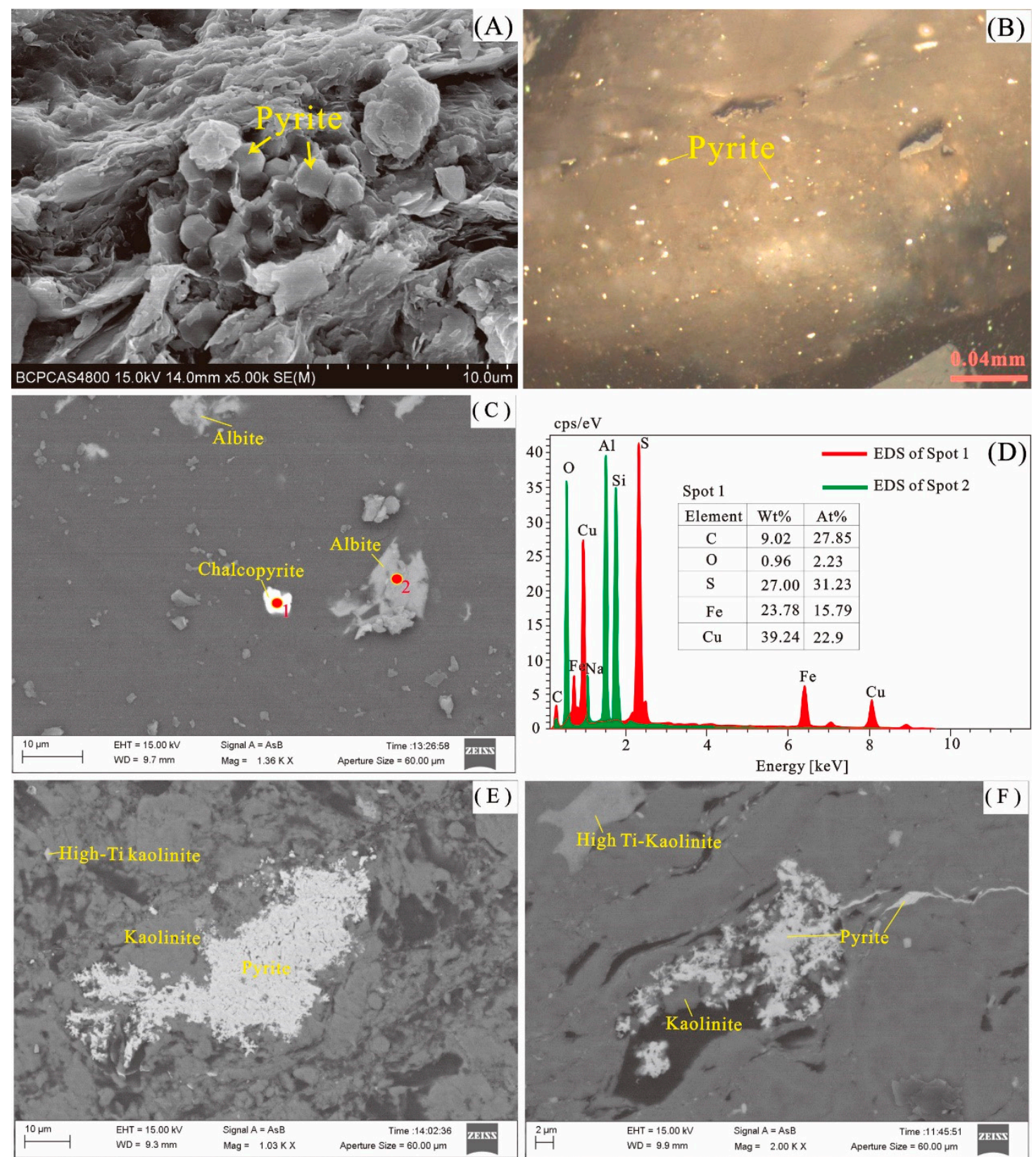

Figure 7. Characteristics of the mineral phases in the samples from Dongpo Mine. (A) Discrete pyrite particles in sample DP5 ${ }^{-2}-5$, SEM under "SE mode". (B) Disseminated pyrite in the veined calcite in sample DP5 ${ }^{-2}-5$, Reflected light, oil immersion. (C) Chalcopyrite and albite in sample DP5 ${ }^{-2}-2$, SEM under "BSE mode". (D) EDS spectrum of Spots 1 and 2. (E) Massive pyrite and kaolinite in sample DP5 ${ }^{-2}-7-p$, SEM under "BSE mode". (F) Fracture-filling pyrite and kaolinite in sample DP5 ${ }^{-2}-3-p$, SEM under "BSE mode". 
6. Other minerals. In addition to the mineral phases discussed above, trace amounts of zircon and anatase (rutile) were also detected in the partings by SEM-EDS. They were not detected by the XRD probably because they were under the detection limit of XRD. Zircon occurs as incomplete quadrilateral bipyramid (Figure 11A,B), while anatase/rutile occurs as individual particles (Figure 11C,D).

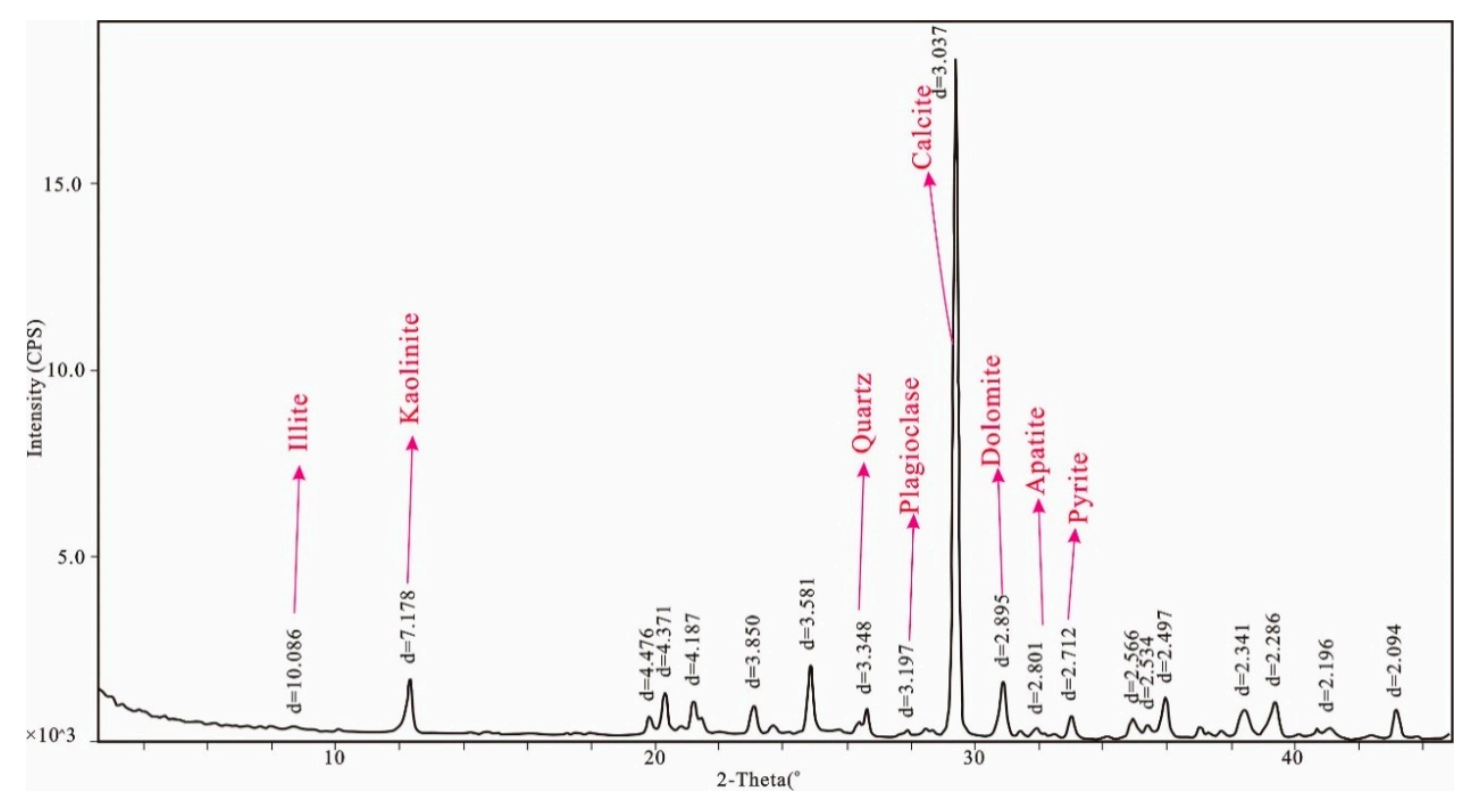

Figure 8. Power X-ray diffraction pattern of the low temperature ash of sample $\mathrm{DP} 5^{-2}-5$ from Dongpo Mine.

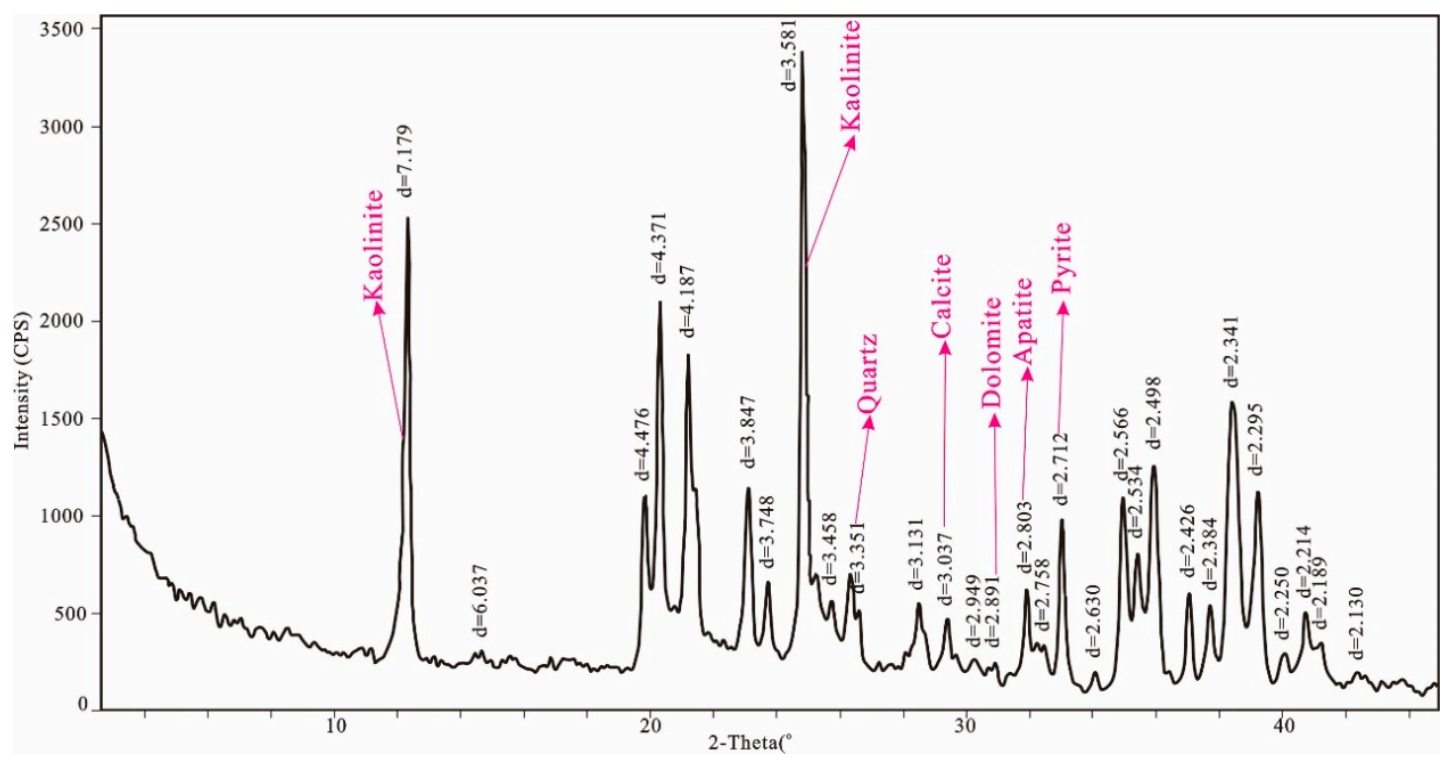

Figure 9. Power X-ray diffraction pattern of the low temperature ash of sample $\mathrm{DP}^{-2}-8$ from Dongpo Mine. 

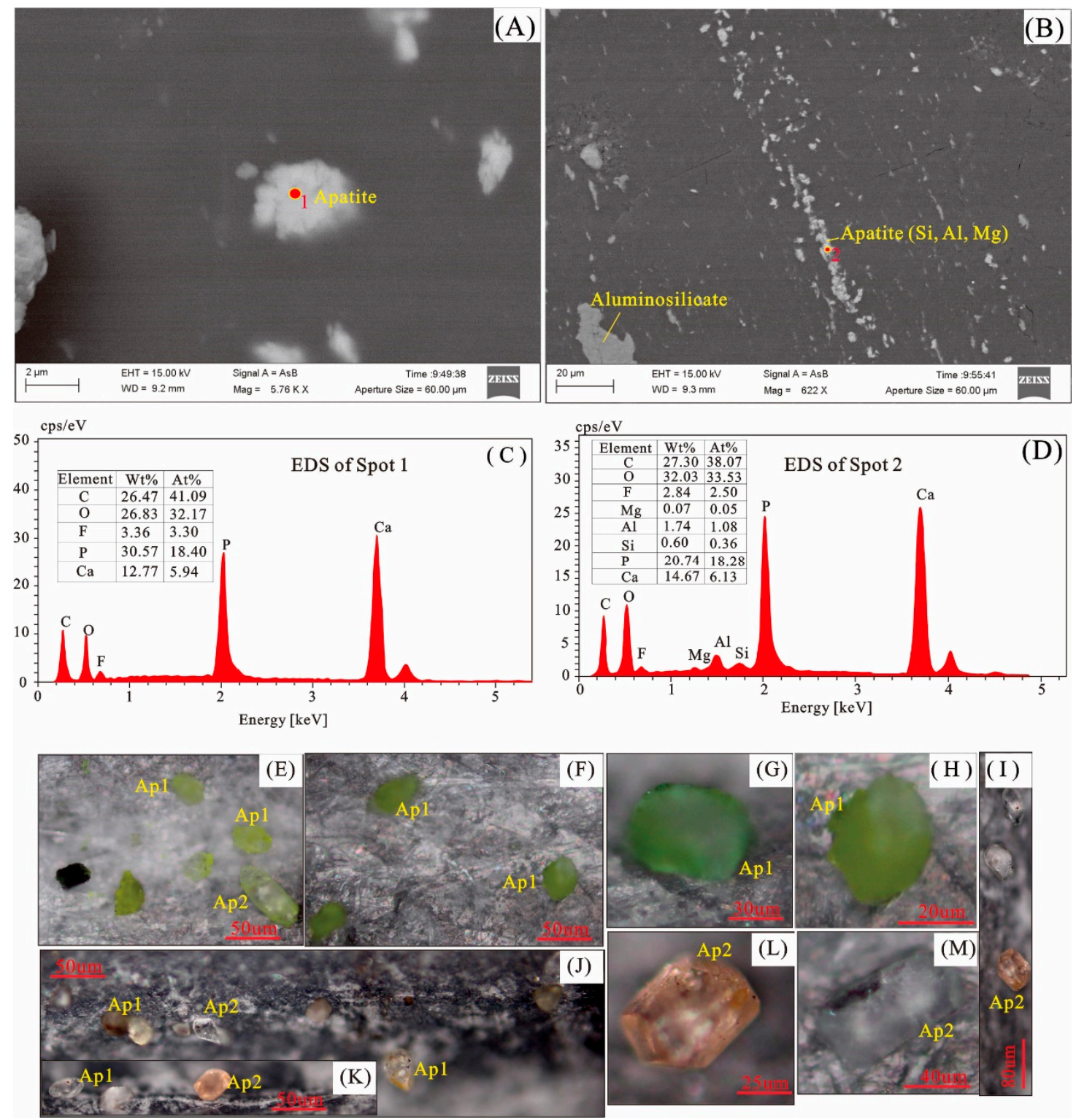

Figure 10. Characteristics of apatite grains from Dongpo Mine (A-D) under SEM (E-M) single apatite crystals under reflected light. (A) Apatite in sample DP5 $5^{-2}$. (B) Composite particles of apatite and aluminosilicate minerals in sample DP5 ${ }^{-2}-8$. (C) EDS spectrum of Spot 1. (D) EDS spectrum of Spot 2. (E-M) apatite in samples DP5 $5^{-2}-8$ and DP5 ${ }^{-2}-5$. Ap1 rounded single apatite crystals. Ap2 euhedral and hexagonal single apatite crystals. 

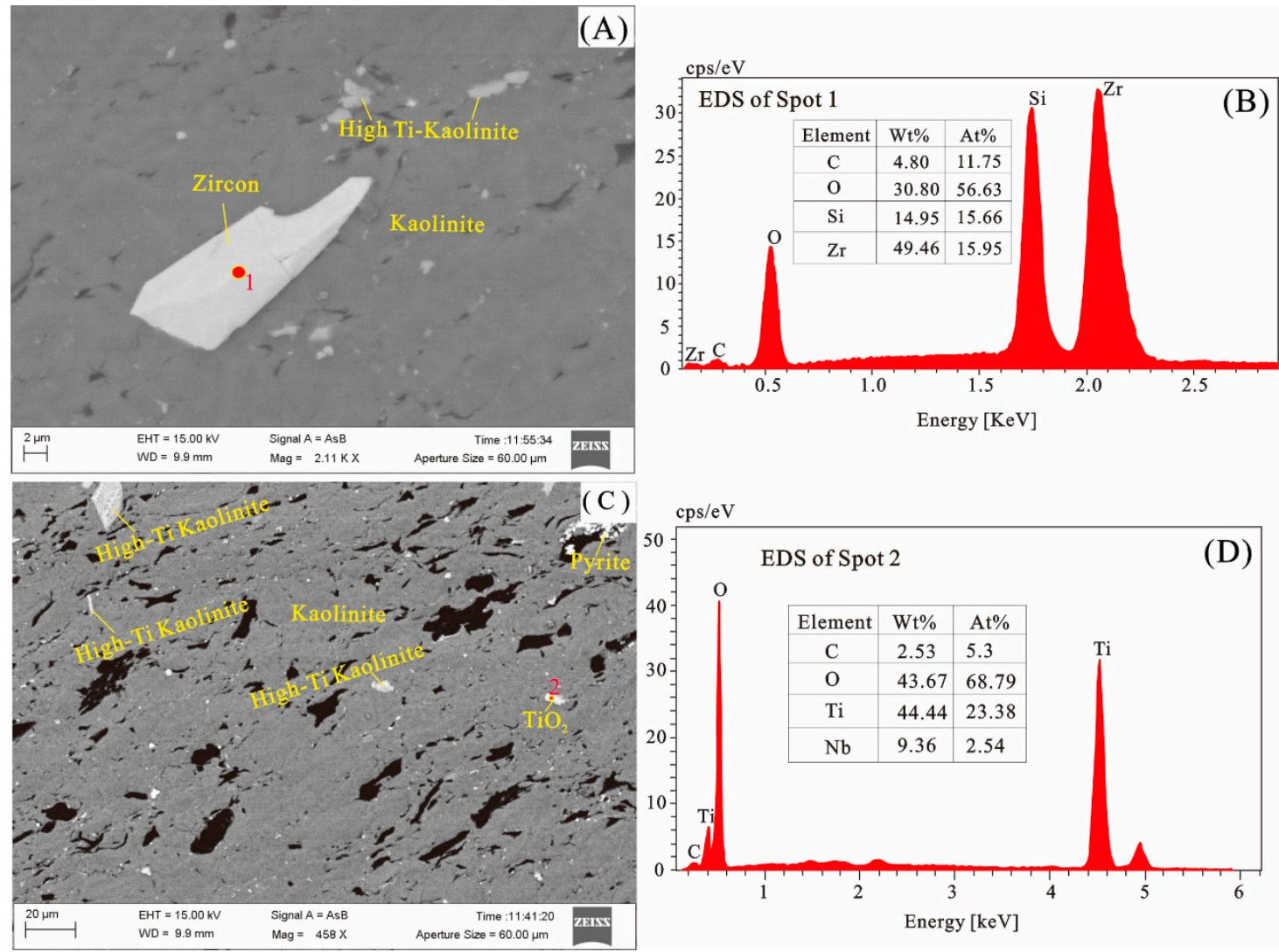

Figure 11. Characteristics of the Zircon and Anatase/Rutile in the Dongpo Mine samples. (A) Zircon and high-Ti kaolinite in sample DP5 ${ }^{-2}-3$-p. (B) EDS spectrum of Spot 1. (C) Anatase/Rutile, pyrite, and kaolinite in sample DP5 ${ }^{-2}-3-p$. (D) EDS spectrum of Spot 2.

\subsection{Geochemistry of the Coal and Host Rocks}

\subsubsection{Major Element Oxides}

Table 4 lists the concentrations of major element oxides in the samples from Dongpo Mine. The major element oxides in the Dongpo coals are mainly represented by $\mathrm{SiO}_{2}$ (ranging from $4.07 \%$ to $7.39 \%)$ and $\mathrm{Al}_{2} \mathrm{O}_{3}(3.87 \%$ to $5.09 \%)$, and to a lesser extent, $\mathrm{Fe}_{2} \mathrm{O}_{3}(1.4 \%$ to $4.33 \%)$ and $\mathrm{CaO}(0.49 \%$ to $5.38 \%)$. Compared with the average values for Chinese coals reported by Dai et al. [23], sample DP5 ${ }^{-2}-5$ is enriched in $\mathrm{MgO}$ and $\mathrm{CaO}$, sample $\mathrm{DP}^{-2}-6$ is enriched in $\mathrm{CaO}$, and most of the coal samples (except for sample DP5 $\left.{ }^{-2}-2\right)$ are enriched in $\mathrm{P}_{2} \mathrm{O}_{5}$. The other major element oxides $\left(\mathrm{SiO}_{2}, \mathrm{TiO}_{2}, \mathrm{Al}_{2} \mathrm{O}_{3}, \mathrm{Fe}_{2} \mathrm{O}_{3}\right.$, $\mathrm{MnO}, \mathrm{Na}_{2} \mathrm{O}$, and $\mathrm{K}_{2} \mathrm{O}$ ) are either close to or lower than those of average Chinese coals (Table 4). The $\mathrm{SiO}_{2} / \mathrm{Al}_{2} \mathrm{O}_{3}$ ratio of the Dongpo coals (1.25 on average) is lower than that of other Chinese coals (1.42), but it is higher than the theoretical $\mathrm{SiO}_{2} / \mathrm{Al}_{2} \mathrm{O}_{3}$ ratio of kaolinite (1.18). The $\mathrm{SiO}_{2} / \mathrm{Al}_{2} \mathrm{O}_{3}$ ratio of the Dongpo coals is higher than that of kaolinite because quartz is present along with abundant kaolinite (Figure 5A,B).

It is worth noting that the $\mathrm{Al}_{2} \mathrm{O}_{3}$ content in the Dongpo coals, which range from $3.87 \%$ to $5.09 \%$ whole-coal average of $4.47 \%$, is slightly lower than that of the Heidaigou ( $10.56 \%$ on average), Haerwusu $(8.89 \%$ on average), and Guanbanwusu $(9.34 \%$ on average) coals $[17,19,20]$. 
Table 4. Concentrations of major element oxides (\%) in the coal benches, partings, roofs, and floor samples from Dongpo Mine.

\begin{tabular}{|c|c|c|c|c|c|c|c|c|c|c|c|c|}
\hline Samples & LOI & $\mathrm{SiO}_{2}$ & $\mathrm{TiO}_{2}$ & $\mathrm{Al}_{2} \mathrm{O}_{3}$ & $\mathrm{Fe}_{2} \mathrm{O}_{3}$ & $\mathrm{MgO}$ & $\mathrm{CaO}$ & $\mathrm{MnO}$ & $\mathrm{Na}_{2} \mathrm{O}$ & $\mathrm{K}_{2} \mathrm{O}$ & $\mathrm{P}_{2} \mathrm{O}_{5}$ & $\mathrm{SiO}_{2} / \mathrm{Al}_{2} \mathrm{O}_{3}$ \\
\hline $\mathrm{DP}^{-2}-0-\mathrm{r}$ & 15.39 & 47.26 & 1.39 & 27.85 & 3.15 & 0.798 & 0.756 & 0.016 & 0.397 & 2.85 & 0.13 & 1.70 \\
\hline $\mathrm{DP}^{-2}-1-\mathrm{r}$ & 12.95 & 46.8 & 1.31 & 30.77 & 3.24 & 0.825 & 0.609 & 0.023 & 0.411 & 2.92 & 0.14 & 1.52 \\
\hline $\mathrm{DP}^{-2}-2$ & 84.87 & 5.83 & 0.162 & 4.21 & 4.33 & 0.146 & 0.49 & 0.004 & 0.131 & 0.131 & 0.034 & 1.38 \\
\hline $\mathrm{DP}^{-2}-3-\mathrm{p}$ & 20.68 & 41.3 & 1.02 & 34.73 & 0.791 & 0.236 & 0.283 & 0.004 & 0.17 & 0.312 & 0.064 & 1.19 \\
\hline $\mathrm{DP}^{-2}-4$ & 84.91 & 5.53 & 0.141 & 4.91 & 1.4 & 0.162 & 0.559 & 0.004 & 0.088 & 0.142 & 0.295 & 1.13 \\
\hline $\mathrm{DP}^{-2}-5$ & 81.99 & 7.39 & 0.079 & 5.09 & 2.26 & 0.415 & 5.38 & 0.009 & 0.043 & 0.053 & 0.169 & 1.45 \\
\hline $\mathrm{DP}^{-2}-6$ & 81. & 4.87 & 0.2 & 4.07 & 2.55 & 0.16 & 4. & $<0.004$ & 0.07 & 0.13 & 0.15 & 1.20 \\
\hline $\mathrm{DP}^{-2}-7-\mathrm{p}$ & 26.98 & 38.68 & 1.54 & 30.53 & 1.07 & 0.294 & 0.166 & 0.006 & 0.161 & 0.494 & 0.076 & 1.27 \\
\hline $\mathrm{DP}^{-2}{ }_{-8}$ & 87.17 & 4.07 & 0.304 & 3.87 & 2.1 & 0.09 & 0.578 & $<0.004$ & 0.05 & 0.024 & 0.263 & 1.05 \\
\hline $\mathrm{DP}^{-2}-9-\mathrm{f}$ & 17.21 & 48.92 & 1.1 & 25.37 & 2.46 & 0.704 & 0.841 & 0.009 & 0.274 & 2.49 & 0.068 & 1.93 \\
\hline WA-coal & 84.41 & 5.60 & 0.17 & 4.47 & 2.45 & 0.20 & 2.59 & $<0.005$ & 0.07 & 0.10 & 0.18 & 1.25 \\
\hline Chinese coal ${ }^{\mathrm{a}}$ & & 8.47 & 0.33 & 5.98 & 4.85 & 0.22 & 1.23 & 0.015 & 0.16 & 0.19 & 0.092 & 1.42 \\
\hline
\end{tabular}

LOI, the loss on ignition; WA-coal, Weighted averages for the Dongpo coal benches; ${ }^{a}$, Major-element oxides in Chinese coals, data from Dai et al. [23].

\subsubsection{Trace Elements}

Based on the enrichment classification of Dai et al. [57], the trace element concentrations of coal can be classified into six categories: unusually enriched (CC $>100)$, significantly enriched $(10<C C<100)$, enriched $(5<\mathrm{CC}<10)$, slightly enriched $(2<\mathrm{CC}<5)$, normal $(0.5<\mathrm{CC}<2)$, and depleted $(\mathrm{CC}<0.5)$. Compared to the average values for world hard coals reported by Ketris and Yudovich. [62], the No. $5^{-2}$ coal is enriched in $\mathrm{Ga}(31.55 \mu \mathrm{g} / \mathrm{g}, \mathrm{CC}=5.26), \mathrm{Li}(84.98 \mu \mathrm{g} / \mathrm{g}, \mathrm{CC}=6.07)$ and are slightly enriched in $\mathrm{Ta}$ $(\mathrm{CC}=3.24), \mathrm{U}(\mathrm{CC}=2.44)$, and $\mathrm{Be}(\mathrm{CC}=2.1)$. It is depleted in $\mathrm{Ni}, \mathrm{V}, \mathrm{Cu}, \mathrm{Sb}, \mathrm{Ba}, \mathrm{Bi}, \mathrm{Cd}, \mathrm{Cs}, \mathrm{Tl}$, and $\mathrm{Rb}$ and has normal abundances of the remaining elements, which are close to the average values for world hard coals (Figure 12A, Table 5).

It should be noted that the Ga contents of the No. $5^{-2}$ coal samples range from $26 \mu \mathrm{g} / \mathrm{g}$ to $34 \mu \mathrm{g} / \mathrm{g}$, with an average of $31.55 \mu \mathrm{g} / \mathrm{g}$, which is slightly lower than that of Heidaigou Mine (45 $\mu \mathrm{g} / \mathrm{g})$ [17], but is much higher than those of Chinese coals $(6.55 \mu \mathrm{g} / \mathrm{g})$ [23], the Haerwusu coals (18 $\mu \mathrm{g} / \mathrm{g})$ [19], and the Guanbanwusu coals $(12.9 \mathrm{mg} / \mathrm{kg}$ ) [20]. The Ga contents of all of the coal samples (except for sample $\left.\mathrm{DP}^{-2}-8\right)$ have reached the industry grade for $\mathrm{Ga}$ in coal $(30 \mu \mathrm{g} / \mathrm{g})$ [63]. The Li content of the No. $5^{-2}$ coal varies from $75.7 \mu \mathrm{g} / \mathrm{g}$ to $91.7 \mu \mathrm{g} / \mathrm{g}$ with an average of $84.98 \mu \mathrm{g} / \mathrm{g}$, which is lower than that of the Haerwusu coals $(116 \mu \mathrm{g} / \mathrm{g})$ [19] and the Guanbanwusu coals (175 $\mu \mathrm{g} / \mathrm{g})$ [20], but is higher than that of the Heidaigou coals $(38 \mu \mathrm{g} / \mathrm{g})$ [17]. Although the Li contents of the Dongpo coals are not high enough to meet the recovery and utilization index for lithium in raw coals $(120 \mu \mathrm{g} / \mathrm{g})$ proposed by Sun et al. [64], the Li contents of most of the coal samples (except for sample DP5 ${ }^{-2}-8$ ) reach the comprehensive evaluation reference index of $\mathrm{Li}(80 \mu \mathrm{g} / \mathrm{g})$ proposed by the China National Administration of Coal Geology in 2017 [65]. The comprehensive evaluation reference index is the minimum content required for comprehensive evaluation and estimation of resources of coal-bearing associated minerals in exploration projects.

Compared to the average values for world clays [66], the partings from Dongpo Mine are significantly enriched in lithium (599 $\mu \mathrm{g}$ on average, $\mathrm{CC}=11.09) ; \mathrm{Bi}(\mathrm{CC}=5.48)$ is enriched; elements $\mathrm{In}, \mathrm{Th}, \mathrm{Ta}, \mathrm{Pb}, \mathrm{Ga}, \mathrm{Hf}$ and $\mathrm{Zr}$ are slightly enriched (Figure 12B). In the roofs, lithium $(\mathrm{CC}=5.32)$ is enriched and elements $\mathrm{Ga}, \mathrm{Bi}, \mathrm{Be}, \mathrm{Ce}, \mathrm{Pb}$ are slightly enriched (Figure 12C). The floor sample is slightly enriched in $\mathrm{Li}, \mathrm{Bi}, \mathrm{Co}, \mathrm{Er}, \mathrm{In}, \mathrm{Pb}, \mathrm{Zn}, \mathrm{Ce}$ (Figure 12D). 
Table 5. Trace element concentrations $(\mu \mathrm{g} / \mathrm{g})$ of the Dongpo coals, partings, and host rocks.

\begin{tabular}{|c|c|c|c|c|c|c|c|c|c|c|c|c|c|c|c|c|c|c|c|c|c|}
\hline Samples & $\mathbf{L i}$ & Be & Sc & V & $\mathrm{Cr}$ & Co & $\mathrm{Ni}$ & $\mathrm{Cu}$ & $\mathrm{Zn}$ & $\mathrm{Ga}$ & $\mathbf{R b}$ & $\mathrm{Sr}$ & $Y$ & Mo & $\mathrm{Cd}$ & In & $\mathrm{Sb}$ & Cs & Ва & La & $\mathrm{Ce}$ \\
\hline $\mathrm{DP}^{-2}-0-\mathrm{r}$ & 287 & 6.03 & 12.2 & 159.4 & 58.6 & 34.42 & 41.6 & 38 & 51.6 & 35 & 141.83 & 409 & 28 & 1.68 & 0.073 & 0.074 & 0.697 & 13.15 & 382.7 & 90.8 & 166.4 \\
\hline $\mathrm{DP5}^{-2}-1-\mathrm{r}$ & 288 & 7.07 & 19.1 & 121 & 87.1 & 22.9 & 31.8 & 35.2 & 66.5 & 40.1 & 142 & 460 & 33.5 & 1.4 & 0.122 & 0.102 & 0.733 & 14.9 & 113 & 98.3 & 176 \\
\hline $\mathrm{DP}^{-2}-2$ & 80.3 & 12.3 & 4.61 & 9.73 & 6.88 & 8.47 & 8.41 & 7.02 & 20.4 & 33.7 & 1.21 & 144 & 19.3 & 1.94 & 0.036 & 0.016 & 0.403 & 0.1 & 42.6 & 5.8 & 9.66 \\
\hline $\mathrm{DP}^{-2}-3-\mathrm{p}$ & 727 & 1.97 & 12.4 & 43.3 & 27.8 & 3.02 & 15.4 & 17.9 & 18.5 & 37.1 & 9.65 & 107 & 19.9 & 2.1 & 0.042 & 0.201 & 0.458 & 1.17 & 135 & 27.1 & 59.7 \\
\hline $\mathrm{DP}^{-2}-4$ & 83.1 & 3.61 & 6.11 & 10.7 & 4.75 & 3.7 & 7.2 & 6.5 & 14.5 & 32.5 & 1.38 & 134 & 17 & 2.6 & 0.034 & 0.021 & 0.081 & 0.179 & 49 & 10.9 & 29.4 \\
\hline $\mathrm{DP}^{-2}-5$ & 91.7 & 1.95 & 3.99 & 10.4 & 8.9 & 3.02 & 3.01 & 1.98 & 10.4 & 34.1 & 0.61 & 147 & 11.6 & 2.3 & 0.036 & 0.026 & 0.09 & 0.23 & 23.4 & 14.7 & 27.4 \\
\hline $\mathrm{DP}^{-2}-6$ & 89.7 & 3.27 & 4.6 & 18.3 & 13.1 & 4.51 & 5.41 & 5.4 & 8.6 & 30.6 & 0.42 & 107 & 6.87 & 1.23 & 0.037 & 0.034 & 0.343 & 0.271 & 44 & 13.4 & 25.9 \\
\hline $\mathrm{DP}^{-2}-7-\mathrm{p}$ & 466 & 5.27 & 14.8 & 71.5 & 48.1 & 6.45 & 17.8 & 36.9 & 36.3 & 59 & 17.4 & 102 & 27.1 & 4.24 & 0.051 & 0.211 & 0.779 & 1.89 & 425 & 45.2 & 88.5 \\
\hline $\mathrm{DP}^{-2}{ }_{-8}^{\mathrm{P}}$ & 75.7 & 1.45 & 4.1 & 19.5 & 12.2 & 4.21 & 17.6 & 10.2 & 28.1 & 26 & 1.14 & 382 & 16.2 & 1.57 & 0.055 & 0.039 & 0.515 & 0.106 & 55.9 & 31.1 & 48.8 \\
\hline $\mathrm{DP5}^{-2}-9-\mathrm{f}$ & 161 & 3.86 & 24.3 & 177 & 132 & 45.1 & 65 & 34.6 & 186 & 31.7 & 141 & 165 & 39.3 & 1.27 & 0.301 & 0.139 & 0.659 & 13.6 & 412 & 77.9 & 152 \\
\hline WA -C & 84.98 & 4.20 & 4.71 & 13.72 & 9.23 & 4.59 & 7.69 & 5.90 & 15.29 & 31.55 & 0.91 & 171.81 & 13.59 & 1.93 & 0.04 & 0.03 & 0.27 & 0.19 & 42.13 & 14.78 & 28.05 \\
\hline WA -P & 599.06 & 3.59 & 13.58 & 57.12 & 37.75 & 4.70 & 16.58 & 27.21 & 27.23 & 47.84 & 13.45 & 104.55 & 23.43 & 3.15 & 0.05 & 0.21 & 0.62 & 1.52 & 123.78 & 35.97 & 73.82 \\
\hline WA -R & 287.50 & 6.55 & 15.65 & 140.20 & 72.85 & 28.66 & 36.70 & 36.60 & 59.05 & 37.55 & 141.92 & 434.50 & 30.75 & 1.54 & 0.10 & 0.09 & 0.72 & 14.03 & 403.85 & 94.55 & 171.20 \\
\hline World coal ${ }^{\mathrm{a}}$ & 14 & 2 & 3.7 & 28 & 17 & 6 & 17 & 16 & 28 & 6 & 18 & 100 & 8.4 & 2.1 & 0.2 & 0.04 & 1 & 1.1 & 150 & 11 & 23 \\
\hline World clay ${ }^{b}$ & 54 & 3 & 15 & 120 & 110 & 19 & 49 & 36 & 89 & 16 & 133 & 240 & 31 & 1.6 & 0.91 & 0.063 & 1.3 & 13 & 460 & 48 & 75 \\
\hline Samples & Pr & $\mathrm{Nd}$ & $\mathrm{Sm}$ & $\mathrm{Eu}$ & $\mathrm{Gd}$ & $\mathrm{Tb}$ & Dy & Ho & Er & $\mathrm{Tm}$ & $\mathrm{Yb}$ & $\mathrm{Lu}$ & $\mathrm{Tl}$ & $\mathrm{Pb}$ & $\mathrm{Bi}$ & Th & $\mathrm{U}$ & $\mathrm{Ta}$ & \multicolumn{2}{|l|}{$\mathrm{Zr}$} & $\mathrm{Hf}$ \\
\hline $\mathrm{DP}^{-2}-0-\mathrm{r}$ & 18.03 & 66.3 & 11.075 & 1.864 & 8.26 & 1.3 & 6.025 & 1 & 3.075 & 0.453 & 3.35 & 0.463 & 0.876 & 34.4 & 1.28 & 28.7 & 6.6 & 2.51 & \multicolumn{2}{|l|}{276} & 4.5 \\
\hline $\mathrm{DP5}^{-2}-1-\mathrm{r}$ & 19.8 & 72.8 & 12.2 & 2.26 & 9.97 & 1.46 & 6.9 & 1.2 & 3.65 & 0.601 & 3.9 & 0.543 & 1 & 32.5 & 1.06 & 23.9 & 5.35 & 1.89 & \multicolumn{2}{|l|}{229} & 6 \\
\hline $\mathrm{DP}^{-2}-2$ & 1.15 & 4.85 & 1.26 & 0.228 & 1.5 & 0.352 & 2.68 & 0.592 & 1.89 & 0.307 & 2.21 & 0.312 & 0.118 & 8.36 & 0.306 & 1.97 & 5 & 0.139 & \multirow{2}{*}{\multicolumn{2}{|c|}{$\begin{array}{l}45.8 \\
412\end{array}$}} & 0.652 \\
\hline $\mathrm{DP}^{-2}-3-\mathrm{p}$ & 7.37 & 28.4 & 5.76 & 0.894 & 4.72 & 0.92 & 4.76 & 0.87 & 2.29 & 0.359 & 2.59 & 0.337 & 0.08 & 27.2 & 1.69 & 39.8 & 4.62 & 3.19 & & & 12.1 \\
\hline $\mathrm{DP}^{-2}{ }^{-}{ }^{1}$ & 4.11 & 16.6 & 3.49 & 0.663 & 3.35 & 0.551 & 2.84 & 0.554 & 1.68 & 0.225 & 1.51 & 0.235 & 0.083 & 6.9 & 0.207 & 2.91 & 6.54 & 0.614 & \multicolumn{2}{|l|}{60.2} & 0.93 \\
\hline $\mathrm{DP}^{-2}-5$ & 3.03 & 10.6 & 2.27 & 0.45 & 2.41 & 0.402 & 2.24 & 0.455 & 1.31 & 0.189 & 1.22 & 0187 & 0.027 & 4.84 & 0.153 & 4.24 & 6.56 & 1.97 & \multicolumn{2}{|l|}{84.9} & 1.29 \\
\hline $\mathrm{DP}^{-2}-6$ & 2.82 & 10 & 1.65 & 0.195 & 1.75 & 0.247 & 1.2 & 0.24 & 0.718 & 0.097 & 0.61 & 0.095 & 0.031 & 5.24 & 0.274 & 1.78 & 2.34 & 1.23 & \multicolumn{2}{|l|}{38} & 1.7 \\
\hline $\mathrm{DP5}^{-2}-7-\mathrm{p}$ & 9.64 & 34.2 & 5.54 & 0.833 & 4.92 & 0.956 & 5.3 & 1.04 & 2.97 & 0.494 & 3.2 & 0.453 & 0.154 & 54.2 & 2.49 & 50 & 7.78 & 5.22 & \multirow{2}{*}{\multicolumn{2}{|c|}{557}} & 15 \\
\hline $\mathrm{DP}^{-2}-8$ & 4.99 & 17.1 & 2.9 & 0.371 & 2.83 & 0.461 & 2.67 & 0.496 & 1.33 & 0.201 & 1.31 & 0.169 & 0.079 & 6.77 & 0.239 & 1.39 & 2.45 & 0.506 & & & 2.15 \\
\hline $\mathrm{DP5}^{-2}-9-\mathrm{f}$ & 17.3 & 65.3 & 11 & 0.76 & 9.5 & 1.58 & 8.37 & 1.51 & 4.23 & 0.737 & 4.82 & 0.654 & 0.755 & 29.4 & 0.927 & 24.3 & 6.39 & 2.06 & \multicolumn{2}{|l|}{$\begin{array}{l}26.9 \\
246\end{array}$} & 7.3 \\
\hline WA -C & 3.22 & 11.86 & 2.32 & & 2.3 & 0.4 & 2. & 0. & 1.34 & 0. & 1. & 0. & 0.0 & 6.25 & 0.23 & 2.54 & 4.63 & 0.97 & \multicolumn{2}{|c|}{52.75} & 1.35 \\
\hline WA -P & 8.48 & 31.24 & 5.65 & 0.86 & 4.82 & 0.94 & 5.02 & 0.95 & 2.62 & 0.43 & 2.89 & 0.39 & 0.12 & 40.44 & 2.08 & 44.80 & 6.17 & 4.19 & \multicolumn{2}{|c|}{483.08} & 13.52 \\
\hline WA -R & 18.92 & 69.55 & 11.64 & 2.06 & 9.12 & 1.38 & 6.46 & 1.10 & 3.36 & 0.53 & 3.63 & 0.50 & 0.94 & 33.45 & 1.17 & 26.30 & 5.98 & 2.20 & \multicolumn{2}{|c|}{252.50} & 5.25 \\
\hline World coal $^{\mathrm{a}}$ & 3.4 & 12 & 2.2 & 0.43 & 2.7 & 0.31 & 2.1 & 0.57 & 1 & 0.3 & 1 & 0.2 & 0.58 & 9 & 1.1 & 3.2 & 1.9 & 0.3 & \multicolumn{2}{|l|}{36} & 1.2 \\
\hline World clay ${ }^{b}$ & 10 & 36 & 8 & 1.2 & 5.8 & 0.83 & 4.4 & 0.9 & 1.9 & 0.5 & 2.5 & 0.39 & 1.3 & 14 & 0.38 & 14 & 4.3 & 1.4 & \multicolumn{2}{|l|}{190} & 5 \\
\hline
\end{tabular}

WA -C, weighted average for coal, based on thickness of coal bench interval; WA -P, weighted average for partings; WA -R, weighted average for roof; ${ }^{\text {, }}$, averages for world hard coals, data from [62]; $b$, averages for world clay, data from [66]. 

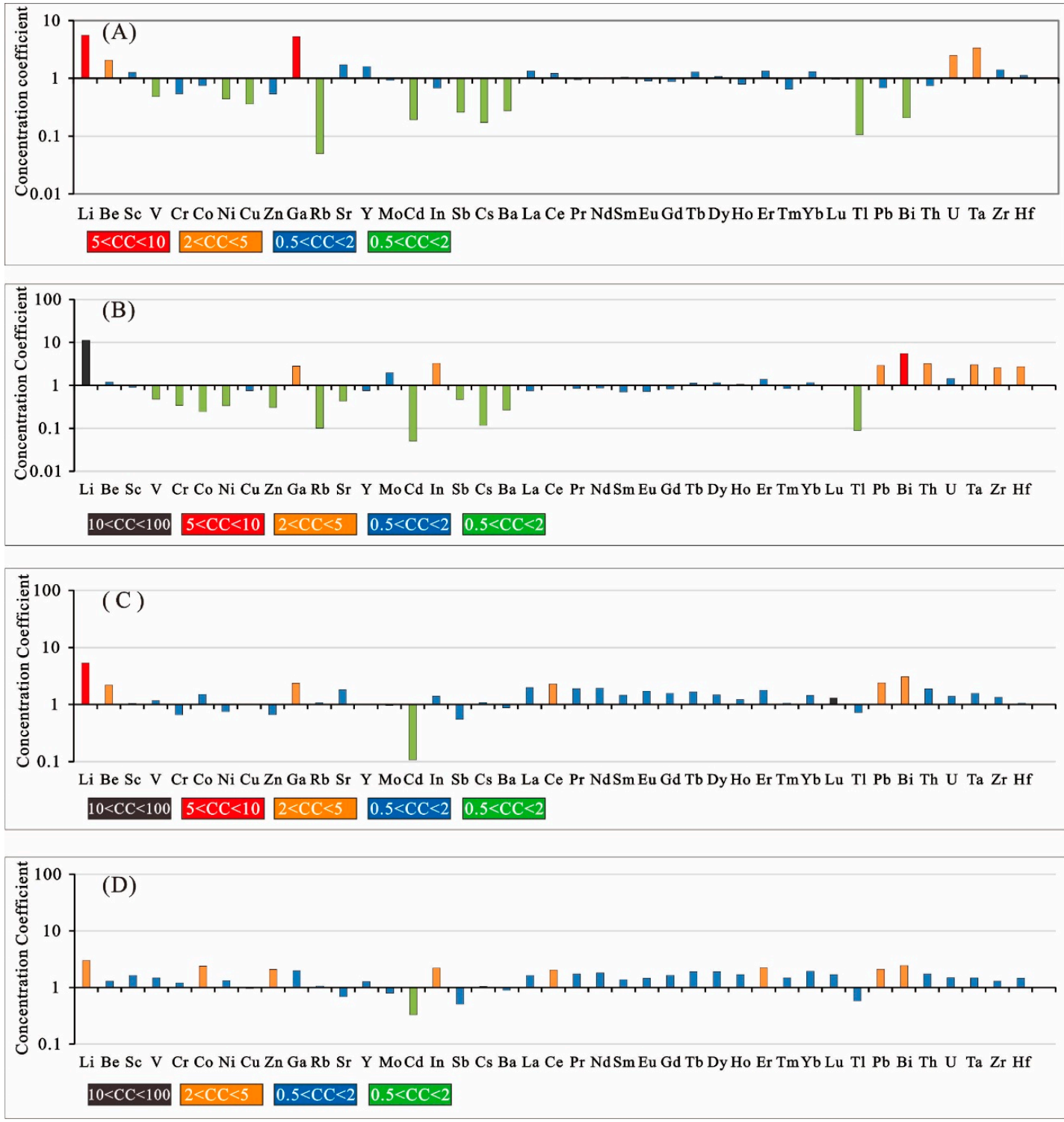

Figure 12. Concentration coefficients (CC) of the trace elements in (A) the coal benches, (B) partings, (C) roofs and (D) floor samples from Dongpo Mine. The data for the coal samples were normalized using the average trace element concentrations of world hard coals [62]. The data for the partings, roof, and floor samples were normalized using the average trace element concentrations of the world clays [66].

Based on the classification of the correlation coefficient (r) between the elemental concentration and the ash yield defined by Xiao et al. [67], the elevated elements in the No. $5^{-2}$ coal, which refers to all slightly enriched $(2<\mathrm{CC}<5)$ or enriched $(5<\mathrm{CC}<10)$ trace elements in coal $(\mathrm{Ga}, \mathrm{Li}, \mathrm{Ta}, \mathrm{U}$, $\mathrm{Be})$, and some slightly enriched or enriched trace elements in partings and host rocks, such as Th, $\mathrm{Zr}, \mathrm{Pb}, \mathrm{Bi}, \mathrm{Er}, \mathrm{Co}$, and $\mathrm{Ce}$, can be classified into four groups (Table 6): (a) Elements with relatively high correlation coefficients ( $r>0.8$ ), including Ga (Figure 13A), Li (Figure 13B), and Zr, indicating a high inorganic affinity; (b) Elements with correlation coefficients of 0.5 to 0.8 , including $\mathrm{U}$, Th, and Ta, suggesting a prevailing inorganic affinity; (c) Elements with low positive correlation coefficient of 0.3 to 0.5 , including $\mathrm{Pb}$ and $\mathrm{Bi}$, indicating an organic-inorganic affinity; and (d) Elements with correlation coefficient of less than 0.3, including Er, Be (Figure 13C), Co, and Ce, indicating a prevailing organic affinity. 
Table 6. Element affinities between the concentration of elevated element in the coal and ash yield or selected elements.

\begin{tabular}{c} 
Correlation with Ash Yield \\
\hline Group a: $\mathrm{r}_{\text {ash }}=0.8-1.0 \mathrm{Ga}(0.89) \mathrm{Li}(0.87) \mathrm{Zr}(0.82)$ \\
Group b: $\mathrm{r}_{\text {ash }}=0.5-0.8 \mathrm{U}(0.67) \mathrm{Th}(0.77) \mathrm{Ta}(0.6)$ \\
Group c: $\mathrm{r}_{\text {ash }}=0.3-0.5 \mathrm{~Pb}(0.42) \mathrm{Bi}(0.38)$ \\
Group d: $\mathrm{r}_{\text {ash }}=-0.3-0.3 \mathrm{Er}(-0.05) \mathrm{Be}(0.09) \mathrm{Co}(-0.16) \mathrm{Ce}(-0.27)$ \\
\hline Correlation coefficients with selected element combinations \\
Aluminosilicate affinity \\
$\mathrm{r}_{\mathrm{Al}-\mathrm{Si}}>0.8 \mathrm{Ga}, \mathrm{Th}, \mathrm{Zr}, \mathrm{U}, \mathrm{TiO}_{2}$ \\
$\mathrm{r}_{\mathrm{Al}-\mathrm{Si}}=0.5-0.8 \mathrm{Li}, \mathrm{Ta}, \mathrm{Bi}, \mathrm{MgO}, \mathrm{CaO}$ \\
$\mathrm{r}_{\mathrm{Al}-\mathrm{Si}}=0.3-0.5 \mathrm{~K} \mathrm{O}_{2} \mathrm{O}$ \\
$\mathrm{Sulfur}$ affinity \\
$\mathrm{r}_{\mathrm{Al}-\mathrm{Si} \mathrm{i}}=-0.3-0.3 \mathrm{Er}, \mathrm{Be}, \mathrm{Co}, \mathrm{Ce}, \mathrm{Pb} \mathrm{O}_{3}, \mathrm{NaO}$ \\
$\mathrm{r}_{\mathrm{s}}>0.8 \mathrm{Be}, \mathrm{Ga}$ \\
$\mathrm{r}_{\mathrm{s}}=0.5-0.8 \mathrm{Co}, \mathrm{Er}, \mathrm{Pb}, \mathrm{U}$ \\
$\mathrm{r}_{\mathrm{S}}=0.3-0.5 \mathrm{Bi}, \mathrm{Ta}, \mathrm{Zr}, \mathrm{SiO}, \mathrm{Al}_{2} \mathrm{O}_{3}$ \\
$\mathrm{r}_{\mathrm{s}}=-0.3-0.3 \mathrm{Th}, \mathrm{Li}$
\end{tabular}

$r_{\text {ash }}$, correlation of elements with ash yield; $\mathrm{r}_{\mathrm{Al}-\mathrm{Si}}$, correlation of elements with $\mathrm{Al}_{2} \mathrm{O}_{3}$ and $\mathrm{SiO}_{2} ; \mathrm{r}_{\mathrm{s}}$, correlation of elements with $S_{p, d}$; the numbers in brackets are the correlation coefficients.
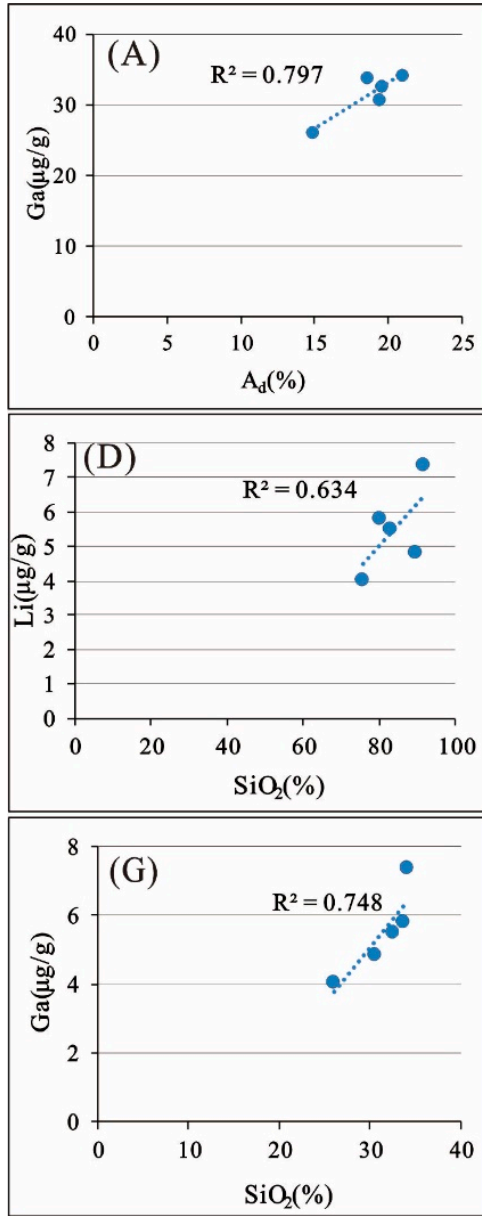
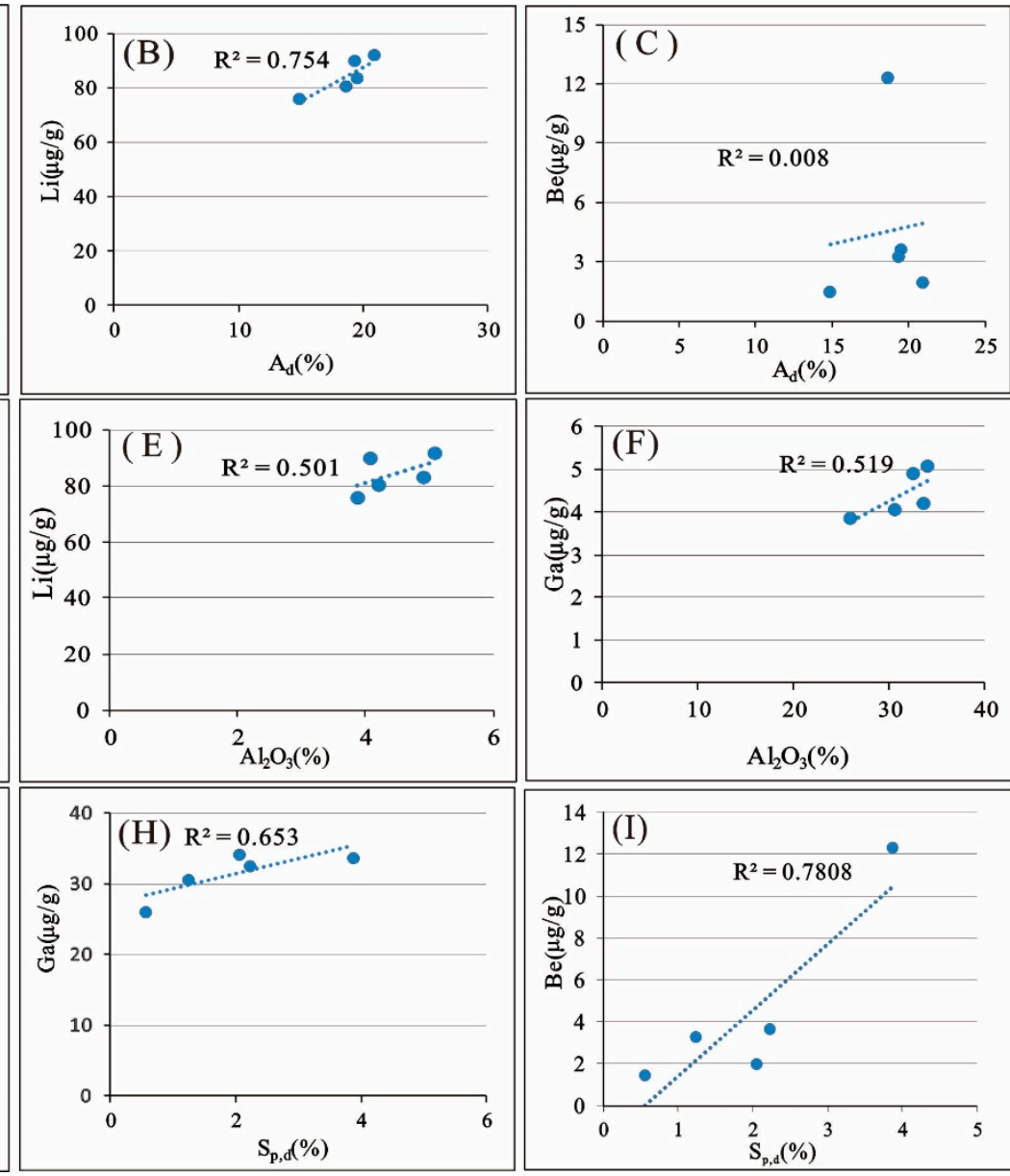

Figure 13. Relationship between several trace elements in the coal and ash yield, $\mathrm{SiO}_{2}, \mathrm{Al}_{2} \mathrm{O}_{3}$, or pyritic sulfur. (A) Plot of $\mathrm{Ga}$ and ash yield. (B) Plot of $\mathrm{Li}$ and ash yield. (C) Plot of Be and ash yield. (D) Plot of $\mathrm{Li}$ and $\mathrm{SiO}_{2}$. (E) Plot of $\mathrm{Li}$ and $\mathrm{Al}_{2} \mathrm{O}_{3}$. (F) Plot of $\mathrm{Ga}$ and $\mathrm{Al}_{2} \mathrm{O}_{3}$. (G) Plot of $\mathrm{Ga}$ and $\mathrm{SiO}_{2}$. (H) Plot of $\mathrm{Ga}$ and pyritic sulfur. (I) Plot of Be and pyritic sulfur. 
In addition, the high correlation coefficients (0.5-0.8 or $>0.8$ ) of $\mathrm{Li}_{-} \mathrm{SiO}_{2}$ (Figure $\left.13 \mathrm{D}\right), \mathrm{Li}^{-\mathrm{Al}_{2} \mathrm{O}_{3}}$ (Figure 13E), Th-SiO ${ }_{2}, \mathrm{Th}-\mathrm{Al}_{2} \mathrm{O}_{3}, \mathrm{Zr}-\mathrm{SiO}_{2}, \mathrm{Zr}-\mathrm{Al}_{2} \mathrm{O}_{3}, \mathrm{Bi}-\mathrm{SiO}_{2}, \mathrm{Bi}-\mathrm{Al}_{2} \mathrm{O}_{3}, \mathrm{Ta}-\mathrm{SiO}_{2}$, and Ta- $\mathrm{Al}_{2} \mathrm{O}_{3}$, indicate that $\mathrm{Li}, \mathrm{Th}, \mathrm{Zr}, \mathrm{Bi}$, and $\mathrm{Ta}$ are mainly present in the aluminosilicate minerals. $\mathrm{Li}, \mathrm{Th}, \mathrm{Zr}, \mathrm{Bi}$, and $\mathrm{Ta}$ exhibit similar variations throughout the coal seam (Figure 14), further indicating the same carriers of these elements. The relatively high correlation coefficients ( $>0.8)$ of $\mathrm{Ga}$, and $\mathrm{Al}_{2} \mathrm{O}_{3}($ Figure $13 \mathrm{~F}), \mathrm{SiO}_{2}$ (Figure 13G), and $\mathrm{S}_{\mathrm{p}, \mathrm{d}}$ (Figure 13H) indicate that Ga occurs in both the aluminosilicate minerals and in pyrite. The high correlation coefficients $(>0.8)$ (Figure 13I) of Be-S $S_{p, d}$ indicate that some of the Be is hosted in pyrite besides in the organic material.

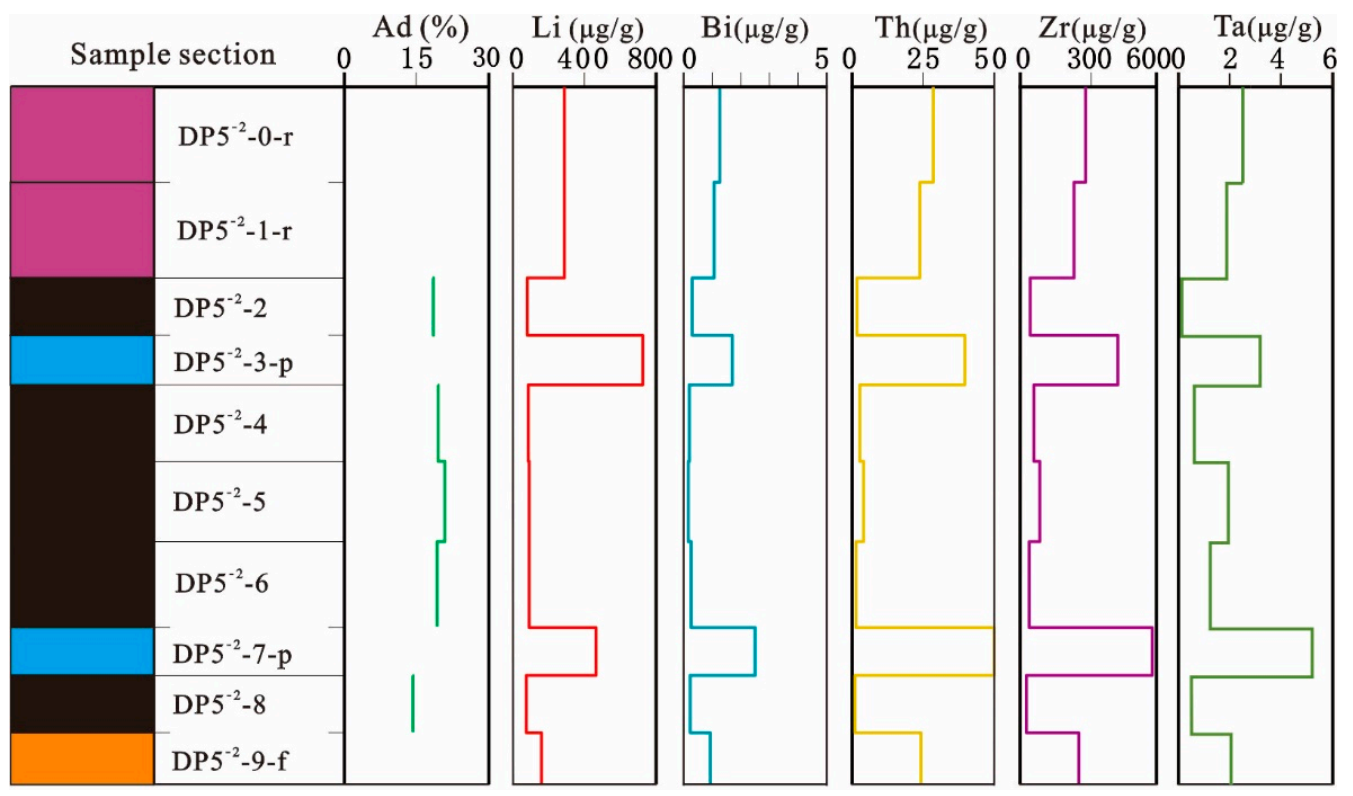

Figure 14. Variations in the ash yield, $\mathrm{Li}, \mathrm{Bi}, \mathrm{Th}, \mathrm{Zr}$, and Ta throughout the coal seam in Dongpo Mine.

The modes of occurrence of $\mathrm{Li}$ in the No. $5^{-2}$ coal samples are similar to that of Li in the Haerwusu and Guanbanwusu coals, which are thought to be associated with the aluminosilicate minerals [20]. However, the modes of occurrence of Ga in the No. $5^{-2}$ coal, which occur in the aluminosilicate minerals and in the pyrite minerals, differ from those of the Junger Coalfield. For example, the Ga in the Heidaigou coals mainly occurs in boehmite, the Ga in the Guanbanwusu coals has a mixed (organic and inorganic) affinity and largely occurs in goyazite, and the Ga in the Haerwusu coals mainly occurs in the boehmite and organic matter $[17,19,20,68]$. In addition, the modes of occurrence of Ga in the No. $5^{-2}$ coal samples, which has little to do with aluminium-bearing minerals (such as boehmite), explain why the $\mathrm{Al}_{2} \mathrm{O}_{3}$ content of the Dongpo coals is lower than those of the Haerwusu and Guanbanwusu coals. However, the Ga content of the No. $5^{-2}$ coal samples is much higher than those of the Haerwusu and Guanbanwusu coals.

\subsubsection{Rare Earth Elements and Yttrium}

A three-fold geochemical classification of REY, which was classified by Seredin and Dai. [1], was used in the present study, including light (LREY: La, Ce, Pr, Nd, and Sm), medium (MREY: Eu, Gd, $\mathrm{Tb}$, Dy, and Y), and heavy (HREY: Ho, Er, Tm, Yb, and Lu) REY. Correspondingly, in comparison with the upper continental crust concentrations (UCC) [69], three enrichment patterns were also identified as L-type (light-REY; $\mathrm{La}_{\mathrm{N}} / \mathrm{Lu}_{\mathrm{N}}>1$ ), M-type (medium-REY; $\mathrm{La}_{\mathrm{N}} / \mathrm{Sm}_{\mathrm{N}}<1, \mathrm{Gd}_{\mathrm{N}} / \mathrm{Lu}_{\mathrm{N}}>1$ ), and H-type (heavy REY; $\mathrm{La}_{\mathrm{N}} / \mathrm{Lu}_{\mathrm{N}}<1$ ) [1]. What's more, the anomalies of redox-sensitive Ce and Eu were expressed as $\mathrm{Eu}_{N} / \mathrm{Eu}_{N}{ }^{*}$, and $\mathrm{Ce}_{N} / \mathrm{Ce}_{N}^{*}$ respectively $[70,71]$.

$$
\left.\mathrm{Eu}_{N} / \mathrm{Eu}_{N}^{*}=\mathrm{Eu}_{N} /\left(\mathrm{Sm}_{\mathrm{N}} \times 0.67\right)+\left(\mathrm{Tb}_{N} \times 0.33\right)\right]
$$




$$
\mathrm{Ce}_{N} / \mathrm{Ce}_{N}{ }^{*}=\mathrm{Ce}_{N} /\left(0.5 \mathrm{La}_{N}+0.5 \operatorname{Pr}_{N}\right)
$$

Previous studies have shown that the measured content of Eu and the identification of positive Eu anomalies by quadrupole-based ICP-MS in coals should be used with great caution due to the interference of $\mathrm{BaO}$ or $\mathrm{BaOH}[70,72]$. If the $\mathrm{Ba} / \mathrm{Eu}$ value is higher than 1000, the $\mathrm{Eu}$ content of the samples is thought to be interferenced by element $\mathrm{Ba}[70,72]$. In this study, the weak relationship between the $\mathrm{Ba}$ and Eu concentrations $\left(\mathrm{R}^{2}=0.1513\right.$; Figure 15), and the low $\mathrm{Ba} / \mathrm{Eu}$ values (50 to 542 , average of 228) of the No. $5^{-2}$ coals, partings, and host rocks suggest that the Eu contents were not interfered by the Ba concentration.

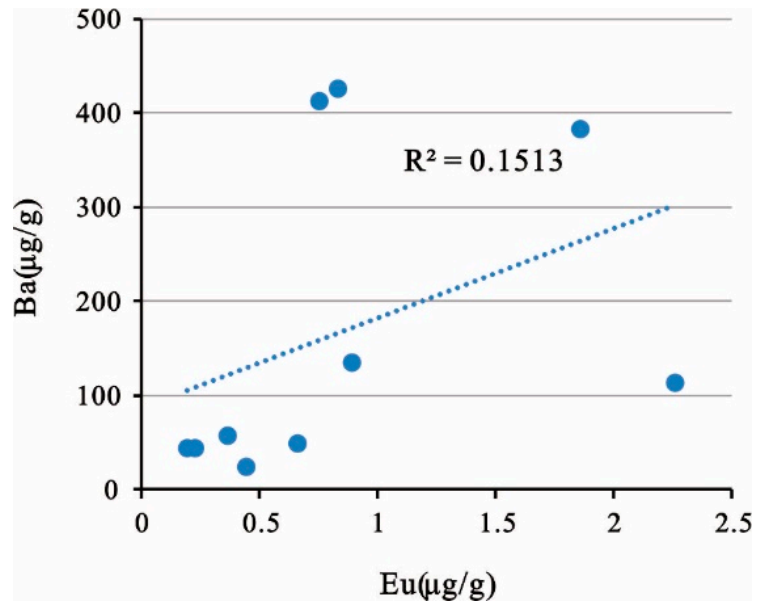

Figure 15. Relationship between Eu and Ba in the Dongpo samples.

The REY concentrations of the coal bench samples (from $52.09 \mu \mathrm{g} / \mathrm{g}$ to $130.93 \mu \mathrm{g} / \mathrm{g}$, weighted average of $82.56 \mu \mathrm{g} / \mathrm{g}$; Table 7) are lower than those of common Chinese coals (136 $\mu \mathrm{g} / \mathrm{g})$ [23], the upper continental crust $(168.37 \mu \mathrm{g} / \mathrm{g})$ [69], the Guanbanwusu coals $(154 \mu \mathrm{g} / \mathrm{g})$ [20], the Haerwusu coals $(228 \mu \mathrm{g} / \mathrm{g})$ [19], and the Heidaigou coals $(259 \mu \mathrm{g} / \mathrm{g})$ [17], but they are slightly higher than those of average world hard coals $(68.6 \mu \mathrm{g} / \mathrm{g})$ [62].

Table 7. REY geochemical parameters for the No. $5^{-2}$ coal samples from Dongpo Mine (REY, $\left.\mu \mathrm{g} / \mathrm{g}\right)$.

\begin{tabular}{|c|c|c|c|c|c|c|c|c|}
\hline Samples & REY & $\mathrm{L} / \mathrm{H}$ & $\mathbf{M} / \mathbf{H}$ & $\mathrm{La}_{\mathbf{N}} / \mathbf{L} \mathbf{u}_{\mathbf{N}}$ & $\mathrm{La}_{\mathrm{N}} / \mathrm{Sm}_{\mathrm{N}}$ & $\mathrm{Gd}_{\mathrm{N}} / \mathrm{Lu}_{\mathrm{N}}$ & $E u_{N} / E u_{N}^{*}$ & $\mathrm{Ce}_{\mathrm{N}} / \mathrm{Ce}_{\mathrm{N}}{ }^{*}$ \\
\hline $\mathrm{DP} 5^{-2}-0-\mathrm{r}$ & 406.39 & 42.28 & 5.45 & 2.09 & 1.23 & 1.50 & 0.91 & 0.93 \\
\hline $\mathrm{DP} 5^{-2}-1-\mathrm{r}$ & 443.08 & 38.32 & 5.47 & 1.93 & 1.21 & 1.55 & 0.99 & 0.91 \\
\hline $\mathrm{DP} 5^{-2}-2$ & 52.09 & 4.28 & 4.53 & 0.20 & 0.69 & 0.40 & 0.70 & 0.85 \\
\hline $\mathrm{DP} 5^{-2}-3-\mathrm{p}$ & 165.97 & 19.91 & 4.84 & 0.86 & 0.71 & 1.18 & 0.76 & 0.96 \\
\hline $\mathrm{DP} 5{ }^{-2}-4$ & 93.11 & 15.34 & 5.8 & 0.49 & 0.47 & 1.20 & 0.94 & 0.98 \\
\hline $\mathrm{DP} 5^{-2}-5$ & 78.46 & 17.26 & 5.09 & 0.84 & 0.97 & 1.09 & 0.94 & 0.93 \\
\hline $\mathrm{DP} 5^{-2}-6$ & 65.79 & 30.55 & 5.83 & 1.50 & 1.22 & 1.55 & 0.59 & 0.96 \\
\hline $\mathrm{DP} 5^{-2}-7-\mathrm{p}$ & 230.35 & 22.44 & 4.79 & 1.06 & 1.22 & 0.91 & 0.72 & 0.97 \\
\hline $\mathrm{DP} 5^{-2}-8$ & 130.93 & 29.87 & 6.42 & 1.96 & 1.61 & 1.41 & 0.63 & 0.88 \\
\hline DP5 ${ }^{-2}-9-f$ & 395.96 & 27.07 & 5.06 & 1.27 & 1.06 & 1.22 & 0.82 & 0.94 \\
\hline WA-C & 82.56 & 17.24 & 5.43 & 1.00 & 0.98 & 1.16 & 0.77 & 0.93 \\
\hline WA-P & 197.53 & 21.3 & 4.81 & 0.96 & 0.96 & 1.05 & 0.74 & 0.96 \\
\hline WA-R & 424.74 & 40.13 & 5.46 & 2.01 & 1.22 & 1.52 & 0.95 & 0.92 \\
\hline
\end{tabular}

$\mathrm{L} / \mathrm{H}$, the ratio of LREY to HREY; M/H, the ratio of MREY to HREY.

The REY contents of the partings and host rocks from Dongpo Mine are approximately two to five times higher than those of the coal bench samples (Table 7). Additionally, the roof and floor samples have much higher REY concentrations $(424.74 \mu \mathrm{g} / \mathrm{g}$ on average and $395.96 \mu \mathrm{g} / \mathrm{g}$, respectively) than those of average world clays $(226.42 \mu \mathrm{g} / \mathrm{g})$ [66] and the upper continental crust $(168.37 \mu \mathrm{g} / \mathrm{g})$ [69]. The REY concentrations of the partings $(197.53 \mu \mathrm{g} / \mathrm{g}$ on average) are slightly lower than those of average world clays but are higher than those of the upper continental crust. 
The LREE/HREE ratio of the the samples varies from 4.28 to 42.28 and is much greater than 1 , revealing a significant LREE enrichment. In addition, a similar pattern was seen for the MREE/HREE ratio (4.79 to 6.42) (Table 7). This is likely because heavy rare earth elements (HREE) are more easily leached by transgressive seawater or groundwater than light rare earth elements (LREE) and medium rare earth elements (MREE), leading to the high LREE/HREE and MREE/HREE ratios.

Based on Seredin-Dai's classification, the REY distribution patterns of the coal samples can be classified into three groups (Figure 16, Table 7): (A) The first group includes samples DP5 ${ }^{-2}-8$ and DP5 ${ }^{-2}-6$ (bottom of the coal seam), which are characterized by a L-REY enrichment relative to the upper continental crust. These samples have distinct negative $\mathrm{Eu}$ anomalies and weak negative Ce anomalies (Figure 16A). (B) The second group includes samples DP5 ${ }^{-2}-4$ to DP5 $5^{-2}-5$ (middle of the coal seam), which are enriched in M-and H-REY and have a weak negative Eu- and Ce-anomalies (Figure 16B); (C) The third group only includes sample DP5 ${ }^{-2}-2$ (top of the coal seam) and which is characterized by H-types, with negative Eu-, and Ce- anomalies (Figure 16C).

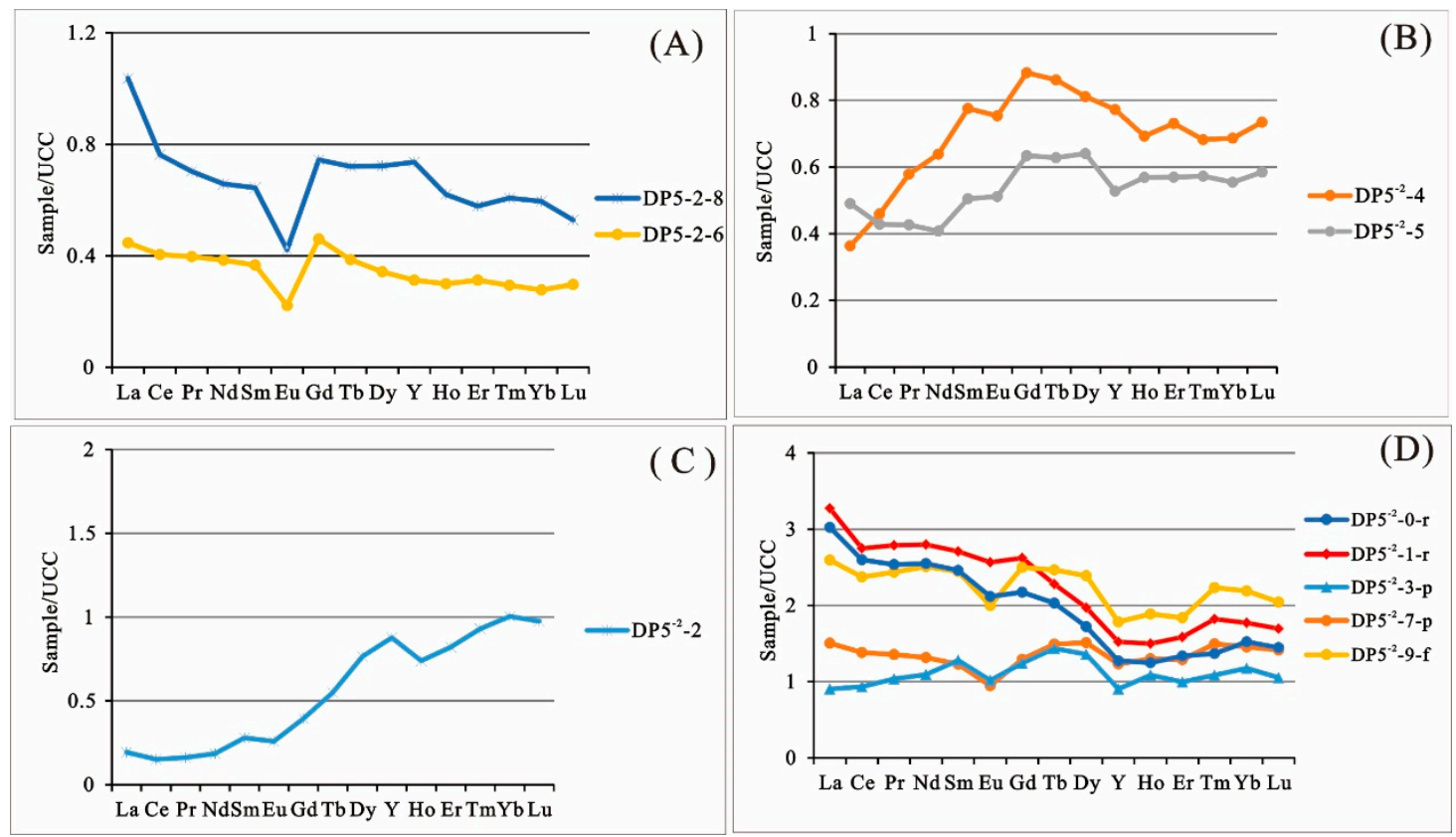

Figure 16. Distribution patterns of rare earth elements and yttrium of the Dongpo Mine samples. REY concentrations are normalized to Upper Continental Crust (UCC) [69]. (A) Distribution patterns of rare earth elements and yttrium in Dongpo coals (L-REY). (B) Distribution patterns of rare earth elements and yttrium in Dongpo coals (M-and H-REY). (C) Distribution patterns of rare earth elements and yttrium in Dongpo coals (H-REY). (D) Distribution patterns of rare earth elements and yttrium in roofs, partings and floor from Dongpo Mine.

The REY distribution patterns of the roof and floor samples are characterized by L-type enrichment and negative Eu-, and Ce- anomalies. Similar to the samples from the middle of the coal seam, the upper parting (Sample DP5 $\left.{ }^{-2}-3-p\right)$, which is located above and adjacent to the middle of the coal seam, shows M-and H-REY types, with negative Eu-, and Ce- anomalies. The lower parting (sample DP5 ${ }^{-2}-7-p$ ), however, is characterized by LREY enrichment, with negative Eu-, and Ce- anomalies (Figure 16D).

\section{Discussion}

The trace element enrichments and mineralization of the coal series are usually thought to be controlled by two aspects: "source" and "convergence". That is, in addition to the primary control of provenance and sedimentary environment, the late tectonic-thermal evolution also has a certain impact on the enrichment of elements in coal measures $[23,25,73,74]$. The input of sediment source 
region, the synchronization volcanic ash, the injection of hydrothermal fluid during syngenetic or early diagenetic stages and the invasion of sea water are likely responsible for the Ga and Li anomalies of the No. $5^{-2}$ coal samples from Dongpo Mine.

\subsection{Sediment Source Region}

The sediment-source region is an important source of the lithophile elements in coals. Previous studies have suggested that the Middle Proterozoic moyite in Yinshan Oldland and the Benxi Formation bauxite are the major sediment-source region of elevated elements (e.g., Li, Ga, REY) of the No. 6 coal in the Junger coalfield, northeastern Ordos Basin [8-10,17,19,20], and thus the terrigenous materials are intermediate-felsic and the coals are generally enriched in $\mathrm{Al}_{2} \mathrm{O}_{3}, \mathrm{Li}, \mathrm{Ga}, \mathrm{Se}, \mathrm{Sr}, \mathrm{Zr}, \mathrm{REE}, \mathrm{Hg}, \mathrm{Pb}$, $\mathrm{Th}, \mathrm{W}, \mathrm{U}$ and $\mathrm{Nb}[17,19,20]$. However, in this study, the Ga and Li anomalies of the No. $5^{-2}$ coal benches in Dongpo Mine, Weibei Coalfield, southeastern Ordos Basin, were not caused by the Benxi Formation bauxite, and the Middle Proterozoic moyite in Yinshan Oldland was the main provenance. The chemical and mineral compositions identified in this study further support this point of view:

1. The $\mathrm{Al}_{2} \mathrm{O}_{3} / \mathrm{TiO}_{2}$ value has been widely used as a useful provenance indicator of sedimentary rocks $[75,76]$ and the sediment-source region of coal deposits $[57,73,77]$, and to infer the original magma composition of volcanic ashes in coal and coal-bearing strata [78,79]. Typical $\mathrm{Al}_{2} \mathrm{O}_{3} / \mathrm{TiO}_{2}$ ratios of sediments derived from mafic, intermediate, and felsic igneous rocks are 3-8, 8-21, and 21-70, respectively [75]. The coal benches in Dongpo Mine have $\mathrm{Al}_{2} \mathrm{O}_{3} / \mathrm{TiO}_{2}$ values ranging from 13.85 to 51.52, with an average of 31.93 (Figure 17), indicating intermediate-felsic compositions for the sediment-source region. In addition, similar to those of the coal benches, the $\mathrm{Al}_{2} \mathrm{O}_{3} / \mathrm{TiO}_{2}$ ratios of the host rocks and partings also suggest terrigenous source rocks with intermediate-felsic compositions (Figure 17). In addition, the ratios of $\mathrm{Zr} / \mathrm{Sc}$ and $\mathrm{Th} / \mathrm{Sc}$ can reveal variabilities in the mineral composition, the degree of sorting, and the heavy mineral content [80] and is suitable for studying the sedimentary source rocks of coal deposits [81]. All of the Dongpo Mine samples fall within the same area, indicating that their source rocks are felsic (Figure 18). An intermediate-felsic source rock for the Dongpo Mine samples is in agreement with the chemical compositions of the N and W Middle Proterozoic moyite in the Yinshan Oldland [2]. During the Late Paleozoic, the Xingmeng Trough on the northern side of the basin subducted under the North China Platform, resulting in the uplift and orogeny of the Yinshan Oldland on the northern margin [82]. During deposition of the No. $5^{-2}$ coal, the basin's terrain was high in the north and low in the south [83], so the intermediate-felsic lavas that erupted from the Yinshan Oldland was an important sediment source during coal formation.

2. The provenance of the No. $5^{-2}$ coal can be further deduced by the rare earth element (REY, or REE if yttrium is not included) and trace-element assemblages [1,57]. The Dongpo coals (including partings, roofs, and floor) and the Junger coals, e.g., the Heidaigou and Haerwusu coals (Figure 19) [17,19], have similar geochemical characteristic, i.e., negative Eu anomalies and enrichment in $\mathrm{Li}, \mathrm{Ga}, \mathrm{Zr}, \mathrm{Pb}$, and $\mathrm{Th}$. Therefore, they may share a similar provenance-the Middle Proterozoic moyite in Yinshan Oldland and the Benxi Formation bauxite. Thus, as with the Junger coals, the Dongpo coal bench samples would also be expected to have high REY contents, with the Benxi Formation bauxite providing most of the REY. However, in addition to variations throughout the seams in the Dongpo Mine and the Junger Coalfield, i.e., high REY contents in the overlying partings and low REY contents in the coal benches of Dongpo Mine, while high REY contents in the coal benches but low REY contents in the overlying partings of the Haerwusu, Heidaigou and Guanbanwusu coals $[17,19,20]$, the REY contents of the coal benches $(73.412 \mu \mathrm{g} / \mathrm{g}$ on average, respectively) from Dongpo Mine, are two to three times lower than those of the coals in the Junger Coalfield (e.g., $154 \mu \mathrm{g} / \mathrm{g}$ on average for the Guanbanwusu coals; $228 \mu \mathrm{g} / \mathrm{g}$ on average for the Haerwusu coals; $259 \mu \mathrm{g} / \mathrm{g}$ on average for the Heidaigou coals) $[17,19,20]$. In addition, according to Dai et al. [19], besides coals being enriched in REY from leaching of the partings, high REY contents in the coal benches in Junger coals are also attributed to the bauxite of the 
weathered surface. Thus, no or weak influence of the weathering crust bauxite leads to a lack of REY enrichment in the No. $5^{-2}$ coals from Dongpo Mine.

3. The $\mathrm{Al}_{2} \mathrm{O}_{3}$ content of the Dongpo coals, which range from $3.87 \%$ to $5.09 \%$ ( $4.47 \%$ on average, on a whole-coal basis), is lower than that of the Heidaigou (10.56\% on average), Haerwusu $(8.89 \%$ on average) and Guanbanwusu $(9.34 \%$ on average) coals $[17,19,20]$. In addition, a number of minerals, including diaspore and boehmite, which are highly enriched in the No. 6 coal in the Junger Coalfield $[2,17,19,20]$, were not observed in the coal samples from Dongpo Mine. Studies by Dai et al. [17] showed that these minerals are thought to have formed from colloidal aluminous gels or solutions, generated in conjunction with the development of bauxitic soils from the Benxi Formation bauxite in the northern and eastern parts of the Junger Coalfield. Then, this material was transported to the peat swamp and reacted to form gibbsite, with the gibbsite altering to boehmite or diaspore through compaction and dehydration. Thus, the evidence further suggests that the anomalies of $\mathrm{Ga}$ and $\mathrm{Li}$ in the No. $5^{-2}$ coal from Dongpo Mine were not caused by the Benxi Formation bauxite.

4. As described above, the modes of occurrence of $\mathrm{Li}$ in the No. $5^{-2}$ coals are similar to those in the Haerwusuand Guanbanwusu coals, which are believed to be associated with aluminosilicate minerals, indicating the same source region - the Middle Proterozoic moyite from the Yinshan Oldland region $[19,20]$. However, the modes of occurrence of Ga in the No. $5^{-2}$ coal, which occur in aluminosilicate minerals and pyrite, differ from those of the Junger Coalfield, indicating that unlike the source of Ga in the Junger Coalfield, the enrichment of Ga in the Dongpo coals is unlikely influenced by the bauxite of Benxi Formation. In addition, the rare metal content of the raw rock determines the content in the rock's weathering products [2]. Since the Li content of the moyite is $26 \mu \mathrm{g} / \mathrm{g}$ [19], and the Ga in intermediate-acid rocks ranges from $19 \mu \mathrm{g} / \mathrm{g}$ to $21 \mu \mathrm{g} / \mathrm{g}$ [84], the contents of Ga and Li in the Middle Proterozoic moyite from Yinshan Oldland are not high enough to provide the high proportion of Ga (from $26 \mu \mathrm{g} / \mathrm{g}$ to $34 \mu \mathrm{g} / \mathrm{g}$, with an average of $31.55 \mu \mathrm{g} / \mathrm{g}$ ) and $\mathrm{Li}$ (from $75.7 \mu \mathrm{g} / \mathrm{g}$ to $91.7 \mu \mathrm{g} / \mathrm{g}$, with an average of $84.98 \mu \mathrm{g} / \mathrm{g}$ ) in the No. $5^{-2}$ coal from Dongpo Mine. Therefore, the Middle Proterozoic moyite in the Yinshan Oldland region provided the basic material source of the trace elements in the No. $5^{-2}$ coal. If the input of this source rock resulted in the enrichment of $\mathrm{Ga}$ and $\mathrm{Li}$, it may only lead to slightly higher $\mathrm{Ga}$ and $\mathrm{Li}$ contents than those of world hard coals, but it could not cause the much higher $\mathrm{Ga}$ and $\mathrm{Li}$ contents mentioned above. The synchronization volcanic ash, hydrothermal fluids and marine environment, which will be discussed below would cause the secondary enrichment of $\mathrm{Ga}$ and $\mathrm{Li}$ in the No. $5^{-2}$ coals.

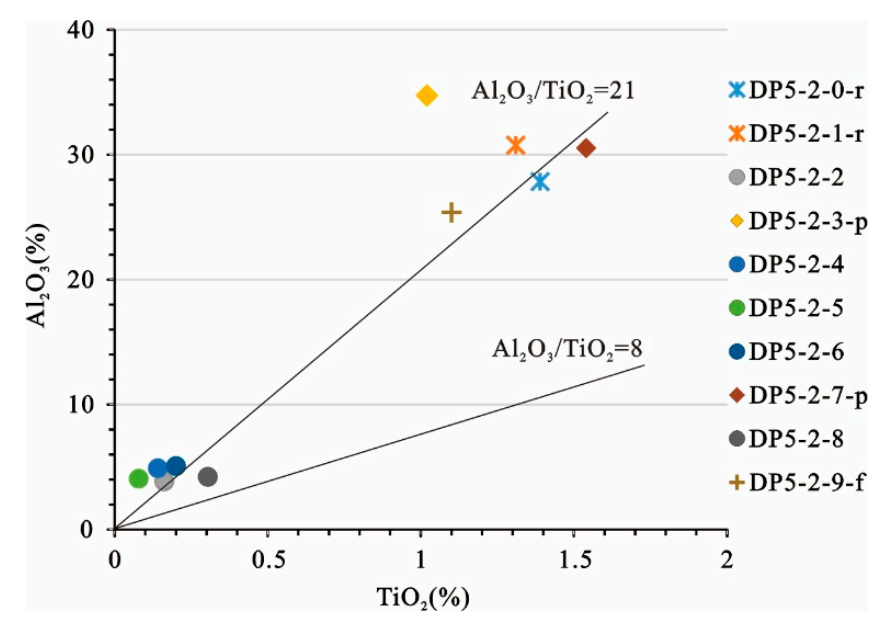

Figure 17. Plot of $\mathrm{Al}_{2} \mathrm{O}_{3}$ versus $\mathrm{TiO}_{2}$ for the coal bench, partings, roof, and floor samples from Dongpo Mine. 


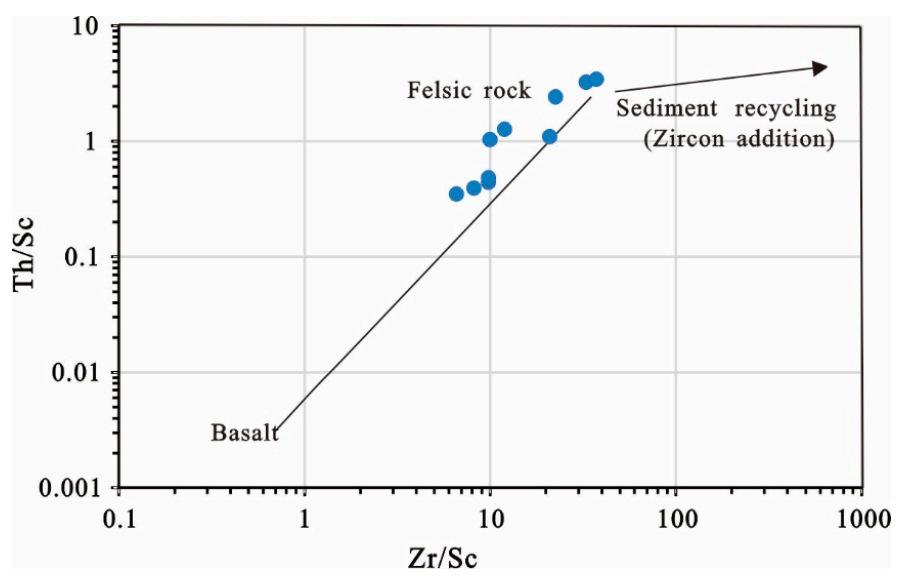

Figure 18. Plot of $\mathrm{Th} / \mathrm{Sc}$ versus $\mathrm{Zr} / \mathrm{Sc}$ for the coal bench, partings, and host rock samples from Dongpo Mine.

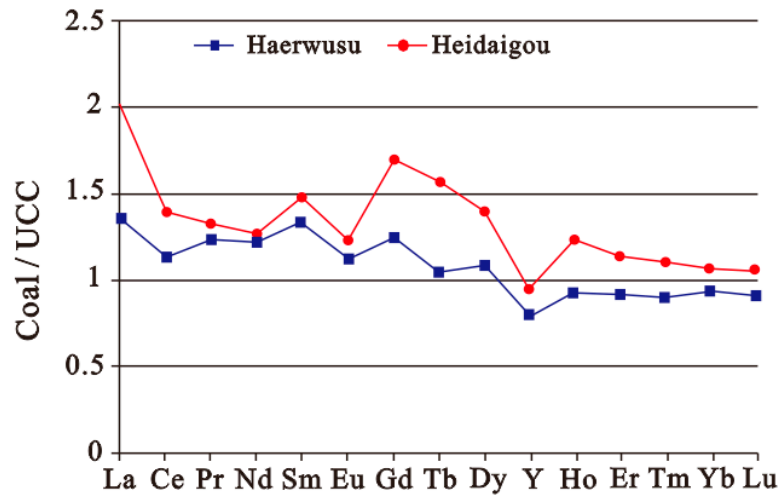

Figure 19. Comparisons of REY distribution patterns among the Heidaigou and Haerwusu coals. REY are normalized by Upper Continental Crust (UCC) [69].

The sediment source regions in southwestern China are much different from those in northern China. The Kangdian Upland, which formed at early stage of the Late Permian and is mainly composed of Emeishan basalts, supplied terrigenous materials for most of the Late Permian coal-bearing areas in southwestern China [23,85-87]. For example, the detrital materials of the coals from the Xinde Mine (eastern Yunnan), the Songzao Coalfield (Chongqing) and the western Guizhou province were mainly derived from the Kangdian Oldland, and the contents of $\mathrm{Sc}, \mathrm{V}, \mathrm{Cr}, \mathrm{Co}, \mathrm{Ni}$, and $\mathrm{Zn}$ in these coals are enriched due to the basaltic composition of source rocks $[27,88,89]$. In addition, the uplands/uplifts surrounding the coal basin in southwestern China were also important positive tectonic elements during the Late Permian and Triassic periods $[87,89]$ and also provided the major source materials for some of the Coalfields, e.g., the Dabashan Uplift, Hannan Upland, and Leshan-Longnvsi Uplift provided material for the Huayingshan (Sichuan) coals [87] while the Vietnam Upland provided material for the Yanshan Coalfield [90]. However, in northern China, during the Late Paleozoic, the Xingmeng Trough subducted beneath the North China Platform, resulting in the uplift and orogeny of the Yinshan Oldland [82]. Thus, the Yinshan Upland, which is located to the north of the North China Plate, served as the dominant sediment-source region for the Permo-Pennsylvanian coals on the North China Plate itself [91], such as the Pennsylvanian coals in the Junger $[17,19,20]$, Daqingshan [68,73], and Weibei Coalfields (as discussed in this study).

\subsection{Influence of Synchronization Volcanic Ash}

It is suggested that the enrichment of Ga and Li in Dongpo Mine was influenced by the input of synchronization volcanic ash for the following reasons: 
1. Eu anomalies in coal are generally not thought to have originated from weathering processes in the sediment source region or during metal transportation from the sediment source region to the peat swamp, but instead inherited from rocks within the sediment source region [70]. The distribution patterns of rare earth elements in the No. $5^{-2}$ coal (including partings, host rocks) are similar to those of intermediate-felsic volcanic rocks that have negative Eu anomalies compared to the upper continental crust. In addition, the enrichment of $\mathrm{Li}, \mathrm{Ga}, \mathrm{Be}$, and $\mathrm{U}$ in the No. $5^{-2}$ coal samples from Dongpo Mine, which are typically enriched in felsic volcanic materials [79], also indicate a felsic volcanic input.

2. Although it was below detection limit of XRD, a small proportion of zircon has been identified in the samples by SEM-EDS analysis (Figure 11A,B). Studies by Zhou et al. [78] showed that detrital zircons in normal sediments of terrigenous origin are quite different in crystal habit and morphology from those of pyroclastic origin. The former are characterized by tetragonal bipyramids with relatively short prisms, making the ratio of length to width (c/a values) around 2 [92]. However, the zircon population from pyroclastics, as a whole, is represented by long, well-developed, tetragonal prisms doubly terminated by pyramids, with c/a values above 2.5 [89]. The c/a values of the zirons in our samples are about 2.8 , indicating a pyroclastic origin.

3. The avanbergite and goyazite detected in the Dongpo coals are intimately associated with the kaolinite (Figure 4F,H) and albite (Figure 5C,D), indicating an authigenic origin. Previous works by Ward et al. [60] concluded that the phosphorus that formed the goyazite-group phosphate minerals may have originally been part of the volcanic ash that was input as a dilutant into the original peat deposit and/or was released from the organic matter in the peat, and then picked up by the Al-rich solutions to form the essentially insoluble aluminophosphates in the pores of the organic matter. Other authors, such as Triplehorn and Bohor [93], Spears et al. [94], and Hill [95], have reported that the goyazite-group minerals in tonsteins associated with coal seams were derived from volcanigenic material altered in a peat swamp. Dai et al. $[17,19,20]$ found that goyazite occurs in the boehmite-rich coal benches of the Heidaigou, Haerwusu and Guanbanwusu Mines and was probably derived from the surface-weathered Benxi Formation bauxite. As discussed above, the No. $5^{-2}$ coal benches in Dongpo Mine were unaffected by the Benxi Formation bauxite. It is likely that the avanbergite and goyazite are related to the volcanigenic material.

4. The high temperature quartz with euhedral hexagonal crystals in the Wangshiwa mine, neighboring the Dongpo Mine, was observed by Wang et al. [58], suggesting the mineral was derived from a volcanic source. In this study, the quartz grains with sharp edges were observed in the roof sample DP5 ${ }^{-2}-1-r$ (Figure 5A). These sharp edges indicate that they may not be a detrital material of terrigenous origin [21,24,54,73]. Yang et al. [32] also found that in sandstone, quartz from a volcanic origin is irregular in shape and the edge angles are clear, with no trace of abrasion. Furthermore, some of the single apatite crystals occur as enhedral and hexagonal grains (Figure 10E,I-M), further indicating the volcanic origin of this mineral [21]. The vermicular kaolinite also indicates a volcanic and subsequent in-situ precipitation origin [22,54,59].

5. In the Pennsylvanian Taiyuan Formation, the tectonic activity gradually became more intense in the southern part of the Ordos Basin with the development of the Qinling orogeny in the Indo-Chinese epoch [96]. Yang et al. [32], used 158 exploratory wells (almost entirely covering each block of the southern Ordos Basin) to determine that the sandstone of each of the coal deposits contained volcanic material. The wide distribution of this volcanic material suggests the frequent and intense volcanic activity in the southern Ordos Basin in the Late Palaeozoic. The geochemical characteristics mentioned above and the mineral association of zircon, avanbergite, goyazite, high temperature quartz, apatite, and book-like kaolinite further confirm that the synchronization volcanic ash input during formation of the No. $5^{-2}$ coal in Dongpo Mine. The diameters of the pyroclastic minerals in the vertical coal profile vary widely, for example, the diameter (the clinodiagonal diameter was used for irregular shapes) of the high temperature quartz in the roof 
samples is $100 \mu \mathrm{m}$ to $150 \mu \mathrm{m}$ (Figure 5A), the diameter of the zircon in the parting sample is about $24 \mu \mathrm{m}$ (Figure 11A) and the diameter of the single apatite crystals with a volcanic origin in the coal benches is $25 \mu \mathrm{m}$ to $100 \mu \mathrm{m}$ (Figure 10E,I-M). The types and sizes of the minerals from a volcanic origin in the coal seams, partings, and host rocks are quite different, indicating that the volcanic activity included multiple eruptions, in a relatively short time interval, that the volcanic material was intermediate-felsic in composition (discussed above), and that the quantity of volcanic ash was too low to form a tonstein layer within the coal seam.

6. According to Dai et al. [23] and Ward [61], volcanic ash affects the trace element concentrations of coal in two ways: (1) Intra-seam tonsteins, widely distributed in the Late Permian coals of southwestern China, may be incorporated with mined coal products, and if not removed in the preparation plant, become part of the feed coal; and (2) Similar volcanic ash that forms tonstein bands intimately dispersed in the peat, and during diagenesis the originally pyroclastic matter becomes part of the inherent mineral matter in the coal seam. Although the mechanism by which alkaline volcanic ash causes enrichments in $\mathrm{Nb}, \mathrm{Ta}, \mathrm{Zr}, \mathrm{Hf}, \mathrm{REE}$, and $\mathrm{Ga}$ has been adequately explained by Dai et al. [30], the mechanism by which intermediate-felsic volcanic ash causes elemental enrichments is still unclear. Since the intermediate-felsic volcanic ash that falls from the sky are enriched in $\mathrm{Ga}$ and $\mathrm{Li}$ [79], later leaching by ground water or hydrothermal solutions could transport elements, such as $\mathrm{Ga}$ and $\mathrm{Li}$, from the volcanic ash into the coal seam, resulting in the enrichment of $\mathrm{Ga}$ and $\mathrm{Li}$ in the No. $5^{-2}$ coal from Dongpo Mine.

Tonsteins refer to thin but persistent layers within coal seams, composed essentially of altered synsedimentary volcanic ash and, in most cases, having a kaolinite-dominant composition [54,55]. In southwestern China, tonstein deposits derived from air-borne pyroclastic material entering the peat-forming environment are widely developed in the coal seams [87]. Four types of tonsteins have been identified in the coals of southwestern China, i.e., felsic, alkali, mafic, and dacitic tonsteins [87]. For example, the concentration and modes of occurrence of the associated elements and minerals in the Late Permian coals were affected by the basaltic volcanic ashes in the western part of Guizhou Province [88] and the Songzao Coalfield (Chongqing) [27], by the acid volcanic ashes in the Yanshan Coalfield (Yunnan) [90], and by felsic volcanic ashes in the Xinde Mine (Yunnan Province) [89]. Zhou et al. [79] and Dai et al. [27,90] showed that the volcanic ashes in the early stage of the Late Permian in southwestern China were alkali and that the volcanic ashes became the acid type in the middle-late stage of the Late Permian. However, in northern China, the compositions of volcanic ashes are mainly felsic to intermediate [97], there are few reports about the influence of other types of volcanic ash on the enrichment of elements in coal. Additionally, Dai et al. [73] found that the tonstein horizons in the Pennsylvanian coal in the Daqingshan Coalfield, northern China are not directly overlain by coal, but by epiclastic clay-rich sediments, indicating that terrigenous material may also have been washed into the coal-forming environment immediately after the volcanic eruptions. This is not consistent with the origins of the tonsteins found in other areas of southwestern China [79,98]. It should be noted that clay-altered alkaline volcanic ash originating from alkaline magmatism is highly enriched in $\mathrm{Nb}(\mathrm{Ta})$, $\mathrm{Zr}$ (Hf), rare earth elements (REE), and Ga, and has been identified as a new type of critical metal deposit with high commercial prospects. This new type of critical metal deposit has been found mainly in southwestern China [30], with few deposits reports in northern China.

\subsection{Influence of Hydrothermal Fluids during the Syngenetic or Early Diagenetic Stage}

The input of hydrothermal fluids, either syngenetically or epigenetically, is one of the major factors responsible for local enrichments of trace elements in coal [7]. The injection of hydrothermal fluid during the syngenetic or early diagenetic stage is the other important factor responsible for the $\mathrm{Ga}$ and Li enrichments of the Dongpo coal, partings, and host rocks for the following reasons:

1. In coal seams, the disseminated pyrite particles are distributed throughout the veined calcite (Figure 7B). The paragenetic association of the pyrite and calcite indicates a pyrite-rich calcite 
hydrothermal origin. Additionally, in the partings, pyrite generally occurs as fracture-fillings (Figure 7F). The precipitation of sulfide minerals in fractures may be derived from sulfate-rich hydrothermal fluids [99].

2. The relationship between the fracture-filling kaolinite and calcite, and the early formation of kaolinite relative to calcite (Figure $6 \mathrm{C}$ ) also indicate multiple injections of hydrothermal fluids. Additionally, ankerite and dolomite occur as cell- (Figures $4 \mathrm{~F}$ and $6 \mathrm{D}$ ) or fracture-fillings (Figure $6 \mathrm{E}, \mathrm{F}$ ), indicating an epigenetic hydrothermal origin.

3. Ti and $\mathrm{Zr}$, are normally resistant to leaching, but they are relatively soluble in highly acidic conditions [100]. The study by Dolcater et al. [101] demonstrated that in Ti-containing kaolinite, $86 \%$ of the total $\mathrm{Ti}$ was in the $\mathrm{TiO}_{2}$ form, primarily as anatase or as anatase with smaller amounts of rutile. It is probable that acidic hydrothermal solutions are favorable for the subsequent substitution of Ti for $\mathrm{Al}$ in developing kaolinite crystals [73].

4. Because the sediment-source region is mainly felsic to intermediate in composition, the REY distribution patterns of the Dongpo coals should exhibit L-REY enrichment type [70]. However, the REY patterns of the middle and upper parts of the coal seams are dominated by M-H-types and H-types respectively, and only the lower part of the seam is L-type REY (Figure 17). The M-REY enrichment of coal is usually caused by the following factors: naturally acidic water [102], including acidic hydrothermal solutions [103,104]; sediment-source regions composed of high-Ti and low-Ti alkali basalts; and the higher absorption of MREY by humic matter compared to LREE and HREE $[105,106]$. The H-REY enrichment of coals is generally caused by a wide spread of natural waters enriched in HREY, which may circulate in coal basins [107]. In this study, the abundant calcite found in samples DP5 $5^{-2}-4$ and DP5 ${ }^{-2}-5$ (middle part of the No. $5^{-2}$ coal seam), and the fracture-filling calcite in the collodetrinite in sample DP5 ${ }^{-2}-5$ (Figure $3 \mathrm{~A}$ ) indicate that acidic calcium - rich solution is most likely responsible for the M-and H-type of REY enrichment of the middle part of the No. $5^{-2}$ coal seam in addition to the higher sorption of MREY and HREY by humic matter than LREY.

5. Compared with the Li contents, the contents of Ga in No. $5^{-2}$ coals from Dongpo Mine exhibit a significant positive correlation with the amount of volatile matter $\left(R^{2}=0.7256\right.$, Figure $\left.20 \mathrm{~A}, \mathrm{~B}\right)$. Based on the geologic setting that deep fractures are well developed in the study area, which cut the Mesozoic strata [33], and according to Wang et al, [2], the Ga may migrate up to the surface from the deeper strata with the geogas. Additionally, as a metal with a low melting point $\left(29.78^{\circ} \mathrm{C}\right)[84], \mathrm{Ga}$ is significantly affected by temperature and will pervade along fractures with the fugitive constituents in hydrothermal fluids [2]. Although Li has significantly higher melting point in comparison with $\mathrm{Ga}$ [84], it could be mobilized by chlorine associated to hot fluids.
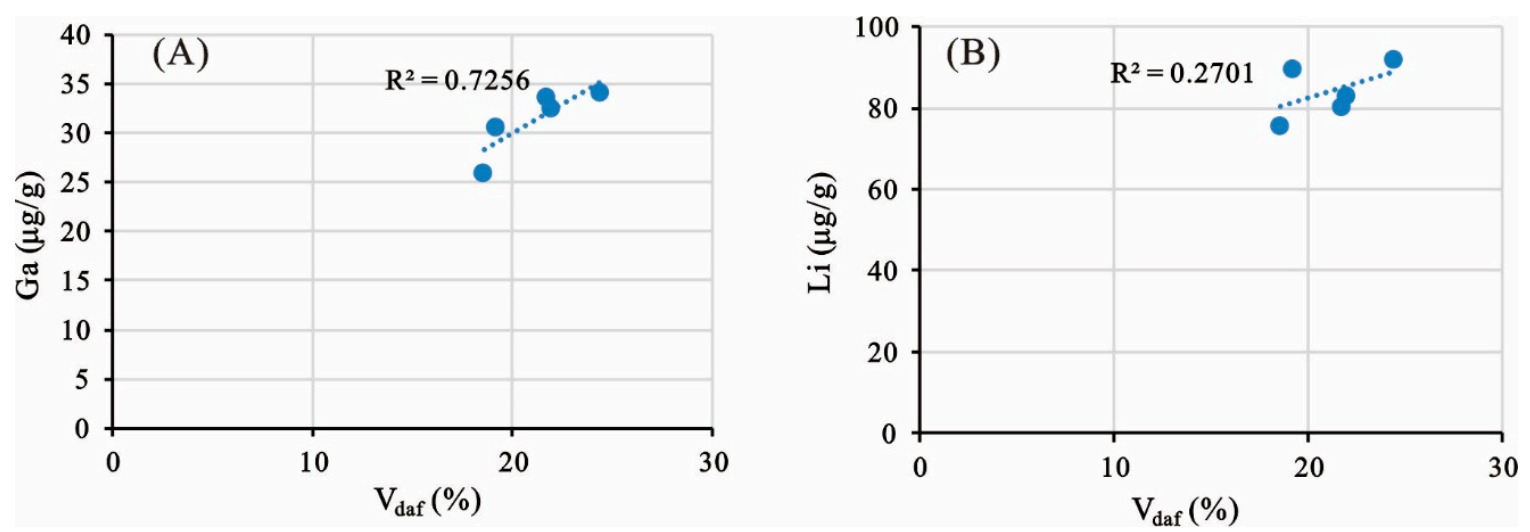

Figure 20. Plots of the amount of volatile matter versus (A) Ga, and (B) Li for the No. $5^{-2}$ coals from Dongpo Mine. 
Hydrothermal fluids are an important factor influencing the local enrichment of some minerals and trace elements in the Late Permian coals in southwestern China [86]. Dai et al. [86,108,109] concluded that the enrichment of some elements in the late Permian coals from the Zhijin and Dafang Coalfields in Guizhou Province and the Fusui Coalfield in Guangxi Province was caused by the influence of low-temperature hydrothermal fluids. The epigenetic hydrothermal fluid was the dominant factor in the enrichment of As in the coal in eastern Yunnan [110]. Recently, studies have shown that hydrothermal solutions are also responsible for the enrichment of U-Re-Se-V-Cr and $\mathrm{Zr}(\mathrm{Hf})-\mathrm{Nb}(\mathrm{Ta})-\mathrm{REE}$ in the Late Permian coals in the Moxinpo Coalfield, Chongqing [6], and the enrichment of U-Se-Mo-V-Re in the coals in the Yishan Coalfield, Guangxi Province [7]. Although the local enrichment of trace elements in coal by hydrothermal fluids is common in southwestern China, this has also occurred in some coals in northern China [23]. For example, the Pennsylvanian coals from the Hailiushu Mine were not subjected to igneous intrusion, but they were significantly influenced by acid hydrothermal solutions, leading to corrosion of the previously-formed minerals in the partings [73].

\subsection{Marine Environments}

The invasion of seawater further contributed to the enrichment of $\mathrm{Ga}$ and $\mathrm{Li}$ in the No. $5^{-2}$ coal, which is supported by the following evidence:

1. Many studies have shown that negative Ce anomalies are considered to be an indication of a marine depositional environment, although the REY concentrations of seawater are low and the transference of REY from the seawater into the peat is still unknown [70]. Generally, $\delta \mathrm{Ce}<0.5$ is indicative of coals formed in oxic marine water, $0.5<\delta \mathrm{Ce}<0.9$ is indicative of suboxic marine water, and $0.9<\delta \mathrm{Ce}<1$ is indicative of anoxic marine water $\left(\delta \mathrm{Ce}=\mathrm{Eu}_{\mathrm{N}} / \mathrm{Eu}_{\mathrm{N}}{ }^{*}\right)$ [111]. The $\delta \mathrm{Ce}$ value of the No. $5^{-2}$ coal varies from 0.85 to 0.98 with an average of 0.93 , indicating that the No. $5^{-2}$ coal was influenced by suboxic to anoxic marine water.

2. The high content of total sulfur (3.55\% on average) and the high proportion of vitrinite-group macerals $(79.6 \%$ on average, mineral-free) further suggest a marine influence during deposition of the No. $5^{-2}$ coal deposition and indicate a reduction environment. Although the elevated concentrations of sulfur in coal are not necessarily the supportive evidence for marine environments [112-114] but reflect epithermal solutions, the high sulfur content of the No. $5^{-2}$ coal from Dongpo Mine is within the range possible for normal sulfate reduction [115] and the No. $5^{-2}$ coal formed in a tidal flat environment, which was influenced by seawater during peat accumulation [33]. These evidences combined with the syngenetic pyrite in the analyzed samples, which is often considered to be an indicator of marine influence [20], indicate that the high sulfur contents of the Dongpo coals is attributed to marine water.

3. The enrichment of gallium and lithium by seawater is mainly seen in the following aspects: On the one hand, marine plankton can enrich some trace elements and provide abundant material sources. On the other hand, seawater changes the $\mathrm{pH}$ value, the Eh value, and the $\mathrm{H}_{2} \mathrm{~S}$ content of peat marshes and produces specific geochemical barriers, which are conducive to the enrichment of trace elements [25]. Qin et al. [116] concluded that the Li contents of coals that were more influenced by seawater are significantly higher than those of coals that were not influenced by seawater, e.g., the coals from the Fugu mining district, Shanbei Permo-Carboniferous Coalfield.

\section{Conclusions}

(1) The No. $5^{-2}$ coal (Taiyuan Formation) from Dongpo Mine, Weibei Coalfield, southeastern Ordos Basin, China, is a low volatile bituminous coal with a low-ash content (18.92\% on average), a high sulfur content (3.55\% on average), and high proportion of vitrinite-group macerals $(79.6 \%$ on average, mineral-free). The coals are enriched in $\mathrm{Ga}(31.55 \mu \mathrm{g} / \mathrm{g}, \mathrm{CC}=5.26)$ and $\mathrm{Li}(84.98 \mu \mathrm{g} / \mathrm{g}$, $\mathrm{CC}=6.07)$ compared to the average values for world hard coals but depleted in $\mathrm{Al}_{2} \mathrm{O}_{3}(4.05 \%$ on 
average) compared to that for Chinese coals. Additionally, the partings are significantly enriched in Li $(599 \mu \mathrm{g} / \mathrm{g}$ on average, $\mathrm{CC}=11.09)$. The roof and floor samples have much higher REY concentrations $(424.74 \mu \mathrm{g} / \mathrm{g}$ on average and $395.961 \mu \mathrm{g} / \mathrm{g}$, respectively) than those of average world clays.

(2) The modes of occurrence of $\mathrm{Li}$ in the No. $5^{-2}$ coals are similar to those of the Haerwusu and Guanbanwusu coals, which are believed to be associated with aluminosilicate minerals. Whereas, the modes of occurrence of $\mathrm{Ga}$ in the No. $5^{-2}$ coal, which occur in the aluminosilicate minerals and pyrite, differ from those of the Junger Coalfield.

(3) The mineral compositions of the coal LTAs mainly include kaolinite, illite, quartz, calcite, pyrite and, to a lesser extent, chlorite, plagioclase, dolomite, ankerite and apatite. The mineral phases in the partings and host rocks are dominantly kaolinite, and, to a lesser extent, quartz, illite, and I/S, along with small proportions of K-feldspar, plagioclase, dolomite, pyrite, and calcite. Miner amounts of svanbergite, goyazite, albite and chalcopyrite in the coal samples and Ti-kaolinite, zircon, and anatase/rutile in the partings were identified by SEM-EDS. Diaspore and boehmite, which are highly enriched in the No. 6 coal from the Junger Coalfield, were not observed in the Dongpo Mine samples.

(4) Based on the geochemical characteristics and mineral association of the high temperature quartz, zircon, avanbergite, goyazite, apatite, and book-like kaolinite, we confirmed the input of intermediate-felsic volcanic ashes into the coal seams (including the partings and host rocks) in the Pennsylvanian Taiyuan Formation in Dongpo Mine, Weibei Coalfield, southeastern Ordos Basin.

(5) In contrast to the origin of enriched elements Ga and Li in Junger Coalfield, which were mainly attributed to the neighboring weathered and oxidized bauxite of the Benxi Formation (Pennsylvanian), the anomalies of $\mathrm{Ga}$ and $\mathrm{Li}$ of the No. $5^{-2}$ high sulfur coal were not affected by the Benxi Formation Bauxite but were caused by the influence of multiple geological factors. The Middle Proterozoic moyite in the Yinshan Oldland region provided the basic trace element source material for the No. $5^{-2}$ coal, and likely led to slightly higher Ga and Li contents than those of world hard coals. The input of synchronization volcanic ash and the injection of hydrothermal fluids during the syngenetic or early diagenetic stage and the invasion of seawater also contributed to the Ga and Li enrichment of the No. $5^{-2}$ coal.

Author Contributions: Formal analysis, G.Q.; Methodology, G.Q., A.W. and J.L.; Supervision, D.C.; Writing-original draft, G.Q., D.C. and Y.W.

Funding: This research was funded by National Natural Science Foundation of China, grant number 41572141, and the Geological Survey Project of China geological survey (grant number DD20160187). And The APC was funded by National Natural Science Foundation of China (grant number 41572141).

Acknowledgments: Special thanks were given to Hao Xu for sample collection and Xinlei Niu for methodology analysis. We are also particularly grateful for the editors and two anonymous reviewers for providing useful suggestions and comments on the manuscript.

Conflicts of Interest: The authors declare no conflict of interest.

\section{References}

1. Seredin, V.V.; Dai, S. Coal deposits as potential alternative sources for lanthanides and yttrium. Int. J. Coal Geol. 2012, 94, 67-93. [CrossRef]

2. Wang, W.; Qin, Y.; Liu, X.; Zhao, J.; Wang, J.; Wu, G.; Liu, J. Distribution, occurrence and enrichment causes of gallium in coals from the Jungar Coalfield, Inner Mongolia. Sci. China Earth Sci. 2011, 54, 1053-1068. [CrossRef]

3. Hower, J.C.; Granite, E.J.; Mayfield, D.B.; Lewis, A.S.; Finkelman, R.B. Notes on contributions to the science of rare earth element enrichment in coal and coal combusition byproducts. Minerals 2016, 6, 32. [CrossRef]

4. Hower, J.C.; Eble, C.F.; Dai, S.; Belkin, H.E. Distribution of rare earth elements in eastern Kentucky coals: Indicators of multiple modes of enrichment? Int. J. Coal Geol. 2016, 160-161, 73-81. [CrossRef] 
5. Dai, S.; Chekryzhov, I.Y.; Seredin, V.V.; Nechaev, V.P.; Graham, I.T.; Hower, J.C.; Ward, C.R.; Ren, D.; Wang, W. Metalliferous coal deposits in East Asia (Primorye of Russia and South China): A review of geodynamic controls and styles of mineralization. Gondwana Res. 2016, 29, 60-82. [CrossRef]

6. Dai, S.; Xie, P.; Jia., S.; Ward, C.R.; Hower, J.C.; Yan, X.; French, D. Enrichment of U-Re-V-Cr-Se and rare earth elements in the Late Permian coals of the Moxinpo Coalfield, Chongqing, China: Genetic implications from geochemical and mineralogical data. Ore Geol. Rev. 2017, 80, 1-17. [CrossRef]

7. Dai, S.; Xie, P.; Ward, C.R.; Yan, X.; Guo, W.; French, D.; Graham, I.T. Anomalies of rare metals in Lopingian super-high-organic-sulfur coals from the Yishan Coalfield, Guangxi, China. Ore Geol. Rev 2017, 88, 235-250. [CrossRef]

8. Sun, Y.; Zhao, C.; Li, Y. Li distribution and mode of occurrences in Li-bearing coal seam \# 6 from the Guanbanwusu Mine, Inner Mongolia, northern China. Energy Explor. Exploit. 2012, 30, 109-130.

9. Sun, Y.; Zhao, C.; Qin, S.; Lin, X.; Li, Z.; Lin, M. Occurrence of some valuable elements in the unique "high-aluminium coals" from the Jungar coalfield, China. Ore Geol. Rev. 2016, 72, 659-668. [CrossRef]

10. Li, J.; Zhuang, X.; Yuan, W.; Liu, B.; Querol, X.; Font, O.; Moreno, N.; Li, J.; Gang, T.; Liang, G. Mineral composition and geochemical characteristics of the Li-Ga-rich coals in the Buertaohai-Tianjiashipan mining district, Jungar Coalfield, Inner Mongolia. Int. J. Coal Geol. 2016, 167, 157-175. [CrossRef]

11. Kolker, A.; Hower, J.C.; Karamalidis, A.K. Introduction to critical elements in coal and coal ash and their recovery, a virtual special issue. Int. J. Coal Geol. 2019, 206, 19-20. [CrossRef]

12. Wang, Z.; Dai, S.; Zou, J.; French, D.; Graham, I.T. Rare earth elements and yttrium in coal ash from the Luzhou power plant in Sichuan, Southwest China: Concentration, characterization and optimized extraction. Int. J. Coal Geol. 2019, 203, 1-14. [CrossRef]

13. Lin, R.; Soong, Y.; Granite, E.J. Evaluation of trace elements in U.S. coals using the USGS COALQUAL database version 3.0. Part I: Rare earth elements and yttrium (REY). Int. J. Coal Geol. 2018, 192, 1-13. [CrossRef]

14. Lin, R.; Soong, Y.; Granite, E.J. Evaluation of trace elements in U.S. coals using the USGS COALQUAL database version 3.0. Part II: Non-REY critical elements. Int. J. Coal Geol. 2018, 192, 39-50. [CrossRef]

15. Arbuzov, S.I.; Chekryzhov, I.Y.; Finkelman, R.B.; Sun, Y.Z.; Zhao, C.L.; Il'enok, S.S.; Blokhin, M.G.; Zarubina, N.V. Comments on the geochemistry of rare-earth elements ( $\mathrm{La}, \mathrm{Ce}, \mathrm{Sm}, \mathrm{Eu}, \mathrm{Tb}, \mathrm{Yb}, \mathrm{Lu}$ ) with examples from coals of north Asia (Siberia, Russian far East, North China, Mongolia, and Kazakhstan). Int. J. Coal Geol. 2019, 206, 106-120. [CrossRef]

16. Dai., S.; Finkelman, R.B. Coal as a promising source of critical elements: Progress and future prospects. Int. J. Coal Geol 2018, 186, 155-164. [CrossRef]

17. Dai, S.; Ren, D.; Chou, C.-L.; Li, S.; Jiang, Y. Mineralogy and geochemistry of the No.6 coal (Pennsylvanian) in the Junger Coalfield, Ordos Basin, China. Int. J. Coal Geol. 2006, 66, 253-270. [CrossRef]

18. Dai, S.; Yan, X.; Ward, C.R.; Hower, J.C.; Zhao, L.; Wang, X.; Zhao, L.; Ren, D.; Finkelman, R.B. Valuable elements in Chinese coals: a review. Int. Geol. Rev. 2018, 60, 590-620. [CrossRef]

19. Dai, S.; Li, D.; Chou, C.-L.; Zhao, L.; Zhang, Y.; Ren, D.; Ma, Y.; Sun, Y. Mineralogy and geochemistry of boehmite-rich coals: New insights from the Haerwusu Surface Mine, Jungar Coalfield, Inner Mongolia, China. Int. J. Coal Geol. 2008, 74, 185-202. [CrossRef]

20. Dai, S.; Jiang, Y.; Ward, C.R.; Gu, L.; Seredin, V.V.; Liu, H.; Zhou, D.; Wang, X.; Sun, Y.; Zou, J.; et al. Mineralogical and geochemical compositions of the coal in the Guanbanwusu Mine, Inner Mongolia, China: Further evidence for the existence of an $\mathrm{Al}$ (Ga and REE) ore deposit in the Jungar Coalfield. Int. J. Coal Geol. 2012, 98, 10-40. [CrossRef]

21. Dai, S.; Ward, C.R.; Graham, I.T.; French, D.; Hower, J.C.; Zhao, L.; Wang, X. Altered volcanic ashes in coal and coal-bearing sequences: A review of their nature and significance. Earth Sci. Rev. 2017, 175, 44-74. [CrossRef]

22. Zhao, L.; Ward, C.R.; French, D.; Graham, I.T. Mineralogy of the volcanic influenced Great Northern coal seam in the Sydney Basin, Australia. Int. J. Coal Geol. 2012, 94, 94-110. [CrossRef]

23. Dai, S.; Ren, D.; Chou, C.-L.; Finkelman, R.B.; Seredin, V.V.; Zhou, Y. Geochemistry of trace elements in Chinese coals: a review of abundances, genetic types, impacts on human health, and industrial utilization. Int. J. Coal Geol. 2012, 94, 3-21. [CrossRef]

24. Dai, S.; Ren, D.; Hou, X.; Shao, L. Geochemical and mineralogical anomalies of the late Permian coal in the Zhijin coalfield of southwest China and their volcanic origin. Int. J. Coal Geol. 2003, 55, 117-138. [CrossRef] 
25. Ren, D.; Zhao, F.; Dai, S.; Zhang, J.; Luo, K. Geochemistry of Trace Elements in Coal; Science Press: Beijing, China, 2006; pp. 399-556. (In Chinese)

26. Li, D.; Tang, Y.; Deng, T.; Chen, K.; Liu, D.; Cheng, F. Mineralogy of the No. 6 Coal from the Qinglong Coalfield, Guizhou Province, China. Energy Explor. Exploit 2008, 26, 347-353. [CrossRef]

27. Dai, S.; Zhou, Y.; Ren, D.; Wang, X.; Li, D.; Zhao, L. Geochemistry and mineralogy of the Late Permian coals from the Songzao Coalfield, Chongqing, Southwestern China. Sci. China Earth Sci. 2007, 50, 678-688. [CrossRef]

28. Dai, S.; Zhou, Y.; Zhang, M.; Wang, X.; Wang, J.; Song, X.; Jiang, Y.; Luo, Y.; Song, Z.; Yang, Z.; et al. A new type of $\mathrm{Nb}(\mathrm{Ta})-\mathrm{Zr}(\mathrm{Hf})-\mathrm{REE}-\mathrm{Ga}$ polymetallic deposit in the late Permian coal-bearing strata, Eastern Yunnan, Southwestern China: Possible economic significance and genetic implications. Int. J. Coal Geol. 2010, 83, 55-63. [CrossRef]

29. Zhao, L.; Dai, S.; Graham, I.T.; Li, X.; Liu, H.; Song, X.; Hower, J.C.; Zhou, Y. Cryptic sediment-hosted critical metal mineralization from eastern Yunnan Province, southwestern China: Mineralogy, geochemistry, relationship to Emeishan alkaline magmatism and possible origin. Ore Geol. Rev. 2017, 80, 116-140. [CrossRef]

30. Dai, S.; Nechaev, V.P.; Chekryzhov, I.Y.; Zhao, L.; Vysotskiy, S.V.; Graham, I.T.; Ward, C.R.; Ignatiev, A.V.; Velivetskaya, T.A.; Zhao, L.; et al. A model for Nb-Zr-REE-Ga enrichment in Lopingian altered alkaline volcanic ashes: Key evidence of H-O isotopes. Lithos 2018, 302-303, 359-369. [CrossRef]

31. Nechaev, V.P.; Chekryzhov, I.Y.; Vysotskiy, S.V.; Ignatiev, A.V.; Velivetskaya, T.A.; Tarasenko, I.A.; Agoshkov, A.I. Isotopic signatures of REY mineralization associated with lignite basins in South Primorye, Russian Far East. Ore Geol. Rev. 2018, 103, 68-77. [CrossRef]

32. Yang, H.; Yang, Y.; Shi, X.; Yin, P. Influence of the Late Paleozoic Volcanic Activity on the Sandstone Reservoir in the Interior of Ordos Basin. Acta Sedimentol. Sin. 2007, 25, 527-534. (In Chinese)

33. Wang, S. Coal Accumulating and Coal Resource Evaluation of Ordos Basin; China Coal Industry Publishing House: Beijing, China, 1996; pp. 164-168, 320-325. (In Chinese)

34. Tongchuan Mining Bureau. Exploration Report of Tongchuan Mining District: Comprehensive Column Map of Dongpo Coal Mine Stratum; Tongchuan Mining Bureau: Shanxi, China, 2007.

35. Yang, J.; Deng, J.; Li, L.; Wang, X.; Liu, Z. Organic Residual Hydrocarbon-Inorganic Mineral Affinity of Trace Elements and Their Influence on Coal-formed Hydrocarbon. Acta Geosci. Sin. 2008, 29, 235-240.

36. Standardization Administration of China; General Administration of Quality Supervision, Inspection and Quarantine of the China. Chinese National Standard GB/T 482-2008; Sampling of Coal Seams; Standand Press of China: Beijing, China, 2008. (In Chinese)

37. ASTM International. ASTM Standard D3173-11; Test Method for Moisture in the Analysis Sample of Coal and Coke; ASTM International: West Conshohocken, PA, USA, 2011.

38. ASTM International. ASTM Standard D3174-11; Annual Book of ASTM Standards. Test Method for Ash in the Analysis Sample of Coal and Coke; ASTM International: West Conshohocken, PA, USA, 2011.

39. ASTM International. ASTM Standard D3175-11; Test Method for Volatile Matter in the Analysis Sample of Coal and Coke; ASTM International: West Conshohocken, PA, USA, 2011.

40. ASTM International. ASTM Standard D3177-02; Standard Test Methods for Total Sulfur in the Analysis Sample of Coal and Coke (Withdrawn 2012); ASTM International: West Conshohocken, PA, USA, 2007.

41. ASTM International. ASTM Standard D2492-02; Standard Test Method for Forms of Sulfur in Coal; ASTM International: West Conshohocken, PA, USA, 2012.

42. Pickel, W.; Kus, J.; Flores, D.; Kalaitzidis, S.; Christanis, K.; Cardott, B.J.; Misz-Kennan, M.; Rodrigues, S.; Hentschel, A.; Hamor-Vido, M.; et al. Classification of liptinite-ICCP System 1994. Int. J. Coal Geol. 2017, 169, 40-61. [CrossRef]

43. International Committee for Coal and Organic Petrology (ICCP). The new vitrinite classification (ICCP System 1994). Fuel 1998, 77, 349-358. [CrossRef]

44. International Committee for Coal and Organic Petrology (ICCP). The new inertinite classification (ICCP System 1994). Fuel 2001, 80, 459-471. [CrossRef]

45. ASTM International. ASTM Standard D2798-11a, 2011. Standard Test Method for Microscopical Determination of the Vitrinite Reflectance of Coal; ASTM International: West Conshohocken, PA, USA, 2011. 
46. National Energy Administration. Standards for Petroleum and Natural Gas Industry of the People's Republic of China SY/T 5368-2016; Identification for Thin Section of Rocks; National Energy Administration: Beijing, China, 2017.

47. Chung, F. Quantitative interpretation of X-ray diffraction patterns of mixtures: I. Matrix flushing method for quantitative multicomponent analysis. J. Appl. Crystallogr. 1974, 7, 519-525. [CrossRef]

48. Dai, S.; Wang, X.; Zhou, Y.; Hower, J.C.; Li, D.; Chen, W.; Zhu, X. Chemical and mineralogical compositions of silicic, mafic, and alkali tonsteins in the late Permian coals from the Songzao Coalfield, Chongqing, Southwest China. Chem. Geol. 2011, 282, 29-44. [CrossRef]

49. ASTM International. Standard Classification of Coals by Rank; ASTM D388-12; ASTM International: West Conshohocken, PA, USA, 2012.

50. Standardization Administration of China; General Administration of Quality Supervision, Inspection and Quarantine of the China. Chinese National Standard GB15224.1-2010; Classification for Quality of Coal-Part 1: Ash; Standand Press of China: Beijing, China, 2010. (In Chinese)

51. Standardization Administration of China; General Administration of Quality Supervision, Inspection and Quarantine of the China. Chinese National Standard GB/T 15224.2-2010; Classification for Quality of Coal- Part 2: Sulfur Content; Standand Press of China: Beijing, China, 2010. (In Chinese)

52. Yang, Q.; Pan, Z.; Weng, C.; Su, Y.; Wang, Z. Discussion on Metamorphic Characteristics and Geological Factors of Permo-Carboniferous Coal in North China; Geological Publishing House: Beijing, China, 1988. pp. 10, 57. (In Chinese)

53. Han, D.; Ren, D.; Wang, Y.; Jin, K.; Mao, H.; Qin, Y. Coal Petrology in China; China University of Mining \& Technology Press: Xuzhou, China, 1996; pp. 104-123. (In Chinese)

54. Dai, S.; Guo, W.; Nechaev, V.P.; French, D.; Ward, C.R.; Spiro, B.F.; Finkelman, R.B. Modes of occurrence and origin of mineral matter in the Palaeogene coal $\left(\right.$ No. $\left.19^{-2}\right)$ from the Hunchun Coalfield, Jilin Province, China. Int. J. Coal Geol 2018, 189, 94-110. [CrossRef]

55. Bohor, B.F.; Triplehorn, D.M. Tonsteins: Altered Volcanic-Ash Layers in Coal-Bearing Sequences; Geological Society of America: Boulder, CO, USA, 1993; p. 44.

56. Ruppert, L.F.; Moore, T.A. Differentiation of volcanic ash-fall and water-borne detrital layers in the Eocene Senakin coal bed, Tanjung Formation, Indonesia. Org. Geochem. 1993, 20, 233-247. [CrossRef]

57. Dai, S.; Seredin, V.V.; Ward, C.R.; Hower, J.C.; Xing, Y.; Zhang, W.; Song, W.; Wang, P. Enrichment of U-Se-Mo-Re-V in coals preserved within marine carbonate successions: Geochemical and mineralogical data from the Late Permian Guiding Coalfield, Guizhou, China. Miner. Depos. 2015, 50, 159-186. [CrossRef]

58. Wang, X.; Dai, S.; Ren, D.; Yang, J. Mineralogy and geochemistry of Al-hydroxide/oxyhydroxide mineral-bearing coals of Late Paleozoic age from the Weibei coalfield, southeastern Ordos Basin, North China. Appl. Geochem. 2011, 26, 1086-1096. [CrossRef]

59. Spears, D.A. The origin of tonsteins, an overview, and links with seatearths, fireclays and fragmental clay rocks. Int. J. Coal Geol. 2012, 94, 22-31. [CrossRef]

60. Ward, C.R.; Corcoran, J.F.; Saxby, J.D.; Read, H.W. Occurrence of phosphorus minerals in Australian coal seams. Int. J. Coal Geol. 1996, 31, 185-210. [CrossRef]

61. Ward, C.R. Analysis, origin and significance of mineral matter in coal: An updated review. Int. J. Coal Geol. 2016, 165, 1-27. [CrossRef]

62. Ketris, M.P.; Yudovich, Y.E. Estimations of Clarkes for carbonaceous biolithes: world average for trace element contents in black shales and coals. Int. J. Coal Geol. 2009, 78, 135-148. [CrossRef]

63. Office of National Mineral Reserve Commission. Handbook of Industrial Requirements for Mineral Resources; Geological Publishing House: Beijing, China, 2014. (In Chinese)

64. Sun, Y.; Zhao, C.; Li, Y.; Wang, J. Minimum mining grade of the selected trace elements in Chinese coal. J. Chi. Coal Soc. 2014, 39, 744-748. (In Chinese)

65. China National Administration of Coal Geology. Comprehensive Evaluation of Mineral Resources in Coal-Bearing Series; National Technical Standard System for Mineral Resources Reserve Construction Project (China); China National Administration of Coal Geology: Beijing, China, 2017. (In Chinese)

66. Grigoriev, N.A. Chemical Element Distribution in the Upper Continental Crust; UBRAS: Ekaterinburg, Russia, 2009; p. 382. (In Russian) 
67. Xiao, L.; Zhao, B.; Duan, P.; Shi, Z.; Ma, J.; Lin, M. Geochemical Characteristics of Trace Elements in the No. 6 Coal Seam from the Chuancaogedan Mine, Jungar Coalfield, Inner Mongolia, China. Minerals 2016, 6, 28. [CrossRef]

68. Dai, S.; Zou, J.; Jiang, Y.; Ward, C.R.; Wang, X.; Li, T.; Xue, W.; Liu, S.; Tian, H.; Sun, X.; et al. Mineralogical and geochemical compositions of the Pennsylvanian coal in the Adaohai Mine, Daqingshan Coalfield, Inner Mongolia, China: Modes of occurrence and origin of diaspore, gorceixite, and ammonian illite. Int. J. Coal Geol. 2012, 94, 250-270. [CrossRef]

69. Taylor, S.R.; McLennan, S.M. The Continental Crust: Its Composition and Evolution; Blackwell Scientific Publications: Palo Alto, CA, USA, 1985; p. 312.

70. Dai, S.; Graham, I.T.; Ward, C.R. A review of anomalous rare earth elements and yttrium in coal. Int. J. Coal Geol. 2016, 159, 82-95. [CrossRef]

71. Bau, M.; Dulski, P. Distribution of yttrium and rare-earth elements in the Penge and Kuruman iron-formations, Transvaal Super group, South Africa. Precambrian Res. 1996, 79, 37-55. [CrossRef]

72. Yan, X.; Dai, S.; Graham, I.T.; He, X.; Shan, K.; Liu, X. Determination of Eu concentrations in coal, fly ash and sedimentary rocks using a cation exchange resin and inductively coupled plasma mass spectrometry (ICP-MS). Int. J. Coal Geol. 2018, 191, 152-156. [CrossRef]

73. Dai, S.; Li, T.; Jiang, Y.; Ward, C.R.; Hower, J.C.; Sun, J.; Liu, J.; Song, H.; Wei, J.; Li, Q.; et al. Mineralogical and geochemical compositions of the Pennsylvanian coal in the Hailiushu Mine, Daqingshan Coalfield, Inner Mongolia, China: Implications of sediment-source region and acid hydrothermal solutions. Int. J. Coal Geol. 2015, 137, 92-110. [CrossRef]

74. Liu, G.; Peng, Z.; Yang, P.; Wang, G.; Zhang, W. Main Factors controlling concentration of trace element in coal. Coal Geol. Exploit 2001, 29, 1-4. (In Chinese)

75. Hayashi, K.I.; Fujisawa, H.; Holland, H.D.; Ohmoto, H. Geochemistry of $\sim 1.9$ Ga sedimentary rocks from northeastern Labrador, Canada. Geochim. Cosmochim. Acta 1997, 61, 4115-4137. [CrossRef]

76. He, B.; Xu, Y.; Zhong, Y.; Guan, J. The Guadalupian-Lopingian boundary mudstones at Chaotian (SW China) are clastic rocks rather than acidic tuffs: Implication for a temporal coincidence between the end-Guadalupian mass extinction and the Emeishan volcanism. Lithos 2010, 119, 10-19. [CrossRef]

77. Hower, J.C.; Eble, C.F.; O’Keefe, J.M.K.; Dai, S.; Wang, P.; Xie, P.; Liu, J.; Ward, C.R.; French, D. Petrology, palynology, and geochemistry of Gray Hawk Coal (Early Pennsylvanian, Langsettian) in Eastern Kentucky, USA. Minerals 2015, 5, 592-622. [CrossRef]

78. Zhou, Y.; Ren, Y.; Tang, D.; Bohor, B. Characteristics of zircons from volcanic ash derived tonsteins in Late Permian coalfields of eastern Yunnan, China. Int. J. Coal Geol. 1994, 25, 243-264. [CrossRef]

79. Zhou, Y.; Bohor, B.F.; Ren, Y.L. Trace element geochemistry of altered volcanic ash layers (tonsteins) in Late Permian coal-bearing formations of eastern Yunnan and western Guizhou Provinces, China. Int. J. Coal Geol. 2000, 44, 305-324. [CrossRef]

80. McLennan, S.; Hemming, S.; McDaniel, D.; Hanson, G. Geochemical approaches to sedimentation, provenance, and tectonics. In Processes Controlling the Composition of Clastic Sediments; Geological Society of America: Boulder, CO, USA, 1993; Volume 284, pp. 21-40.

81. Yang, N.; Tang, S.; Zhang, S.; Xi, Z.; Li, J.; Yuan, Y.; Guo, Y. In seam variation of element-oxides and trace elements in coal from the eastern Ordos Basin, China. Int. J. Coal Geol. 2018, 197, 31-41. [CrossRef]

82. Wang, G. The Study of Sources and Sequence-Lithofaces Palaeogeography of Upper Palaezoic, Northern Ordos. Ph.D. Thesis, Chengdu University of Technology, Chengdu, China, 2011. (In Chinese).

83. Qu, X.; Li, J.; Sun, C.; Zhang, Q.; Tang, S.; Wei, J. Geochemistry characteristics of rare earth elements in the late Paleozoic black shale from eastern Ordos Basin. J. China Coal Soc. 2018, 43, 1083-1093. (In Chinese)

84. Liu, Y.; Cao, L.; Li, Z.; Wang, H.; Chu, T.; Zhang, J. Geochemistry of the Elements; Science Press: Beijing, China, 1984; pp. 125-380. (In Chinese)

85. China National Administration of Coal Geology. Sedimentary Environments and Coal Accumulation of Late Permian Coal Formation in Western Guizhou, Southern Sichuan and Eastern Yunnan, China; Chongqing University Press: Chongqing, China, 1996; pp. 1-275. (In Chinese)

86. Dai, S.; Zhang, W.; Ward, C.R.; Seredin, V.V.; Hower, J.C.; Li, X.; Song, W.; Wang, X.; Kang, H.; Zheng, L.; et al. Mineralogical and geochemical anomalies of Late Permian coals from the Fusui Coalfield, Guangxi Province, southern China: Influences of terrigenous materials and hydrothermal fluids. Int. J. Coal Geol. 2013, 105, 60-84. [CrossRef] 
87. Dai, S.; Luo, Y.; Seredin, V.V.; Ward, C.R.; Hower, J.C.; Zhao, L.; Liu, S.; Zhao, C.; Tian, H.; Zou, J. Revisiting the late Permian coal from the Huayingshan, Sichuan, Southwestern China: Enrichment and occurrence modes of minerals and trace elements. Int. J. Coal Geol. 2014, 122, 110-128. [CrossRef]

88. Dai, S.; Ren, D.; Tang, Y.; Yue, M.; Hao, L. Concentration and distribution of elements in Late Permian coals from western Guizhou Province, China. Int. J. Coal Geol. 2005, 61, 119-137. [CrossRef]

89. Dai, S.; Li, T.; Seredin, V.V.; Ward, C.R.; Hower, J.C.; Zhou, Y.; Zhang, M.; Song, X.; Song, W.; Zhao, C. Origin of minerals and elements in the Late Permian coals, tonsteins, and host rocks of the Xinde Mine, Xuanwei, eastern Yunnan, China. Int. J. Coal Geol. 2014, 121, 53-78. [CrossRef]

90. Dai, S.; Ren, D.; Zhou, Y.; Chou, C.-L.; Wang, X.; Zhao, L.; Zhu, X. Mineralogy and geochemistry of a super high-organic-sulfur coal, Yanshan Coalfield, Yunnan, China: Evidence for a volcanic ash component and influence by submarine exhalation. Chem. Geol. 2008, 255, 182-194. [CrossRef]

91. Han, D.; Yang, Q. Coal Geology of China; Publishing House of China Coal Industry: Beijing, China, 1980; pp. 2-3. (In Chinese)

92. Zhou, Y. Precise identification and correlation for coal seams using ziron features and trace elements in tonsteins. Coal Geol. Exploit. 1992, 20, 18-23. (In Chinese)

93. Triplehorn, D.; Bohor, B. Volcanic ash layers in coal: Origin, distribution, composition and significance. In ACS Symposium Series; American Chemical Society: Washington, DC, USA, 1986; pp. 90-98.

94. Spears, D.A.; Duff, P.M.D.; Caine, P.M. The west Warterburg tonstein, South Africa. Int. J. Coal Geol. 1988, 9 , 221-233. [CrossRef]

95. Hill, P.A. Tonsteins of Hat Creek, British Columbia: a preliminary study. Int. J. Coal Geol. 1988, 10, $155-175$. [CrossRef]

96. Li, Z. Response to Qinling Orogenic with the Tectonic and Sedimentary Evolution of Ordos Basin. Ph.D. Thesis, Chinese Academy of Geological Sciences, Beijing, China, 2011. (In Chinese)

97. Wang, S.; Ge, L. Geochemical characteristics of rare earth elements in kaolin rock from Daqingshan coalfield. Coal Geol. Explor. 2007, 35, 1-5. (In Chinese)

98. Zhao, L.; Ward, C.R.; French, D.; Graham, I.T. Mineralogical composition of Late Permian coal seams in the Songzao Coalfield, southwestern China. Int. J. Coal Geol. 2013, 116-117, 208-226. [CrossRef]

99. Li, J.; Zhuang, X.; Querol, X.; Font, O.; Izquierdo, M.; Wang, Z. New data on mineralogy and geochemistry of high-Ge coals in the Yimin coalfield, Inner Mongolia, China. Int. J. Coal Geol. 2014, 125, 10-21. [CrossRef]

100. Ward, C.R.; Spears, D.A.; Booth, C.A.; Staton, I.; Gurba, L.W. Mineral matter and trace elements in coals of the Gunnedah Basin, New South Wales, Australia. Int. J. Coal Geol. 1999, 40, 281-308. [CrossRef]

101. Dolcater, D.L.; Syers, J.K.; Jackson, M.L. Titanium as free oxide and substituted forms in kaolinites and other soil minerals. Clays Clay Miner. 1970, 18, 71-79. [CrossRef]

102. Johanneson, K.H.; Zhou, X. Geochemistry of the rare earth element in natural terrestrial waters: A review of what is currently known. Chin. J. Geochem. 1997, 16, 20-42. [CrossRef]

103. McLennan, S.M. Rare earth elements in sedimentary rocks: Influence of provenance and sedimentary processes. Rev. Mineral. Geochem. 1989, 21, 169-200.

104. Michard, A. Rare earth element systematics in hydrothermal fluids. Geochim. Cosmochim. Acta 1989, 53, 745-750. [CrossRef]

105. Seredin, V.V.; Shpirt, M.Y. Rare earth elements in the humic substance of metalliferous coals. Lithol. Miner. Resour. 1999, 34, 244-248.

106. Seredin, V.V.; Shpirt, M.Y. REE Contents and Distribution in Humic Matter of REE-Rich Coals. In Mineral Deposits: Processes to Processing; Stanley, C.J., Ed.; AA Balkema: Rotterdam, The Netherlands, 1999; pp. 267-269.

107. Seredin, V.V. Major regularities of the REE distribution in coal. In Doklady Earth Sciences; Pleiades Publishing, Ltd.: Moscow, Russia, 2001; pp. 250-253.

108. Dai, S.; Chou, C.-L.; Yue, M.; Luo, K.; Ren, D. Mineralogy and geochemistry of a Late Permian coal in the Dafang Coalfield, Guizhou, China: Influence from siliceous and iron-rich calcic hydrothermal fluids. Int. J. Coal Geol. 2005, 61, 241-258. [CrossRef]

109. Dai, S.; Li, D.; Ren, D.; Tang, Y.; Shao, L.; Shi, Z. Geochemistry of the late Permian No.30 Coal Seam, Zhijin Coalfield of Southwest China: Influence of the siliceous low-temperature hydrothermal fluid. Appl. Geochem. 2004, 19, 1315-1330. [CrossRef] 
110. Zhou, Y.; Ren, Y. Distribution of arsenic in coals of Yunnan Province, China, and its controlling factors. Int. J. Coal Geol. 1992, 20, 85-98. [CrossRef]

111. Chen, J.; Algeo, T.J.; Zhao, L.; Chen, Z.-Q.; Cao, L.; Zhang, L.; Li, Y. Diagenetic uptake of rare earth elements by bioapatite, with an example from Lower Triassic conodonts of South China. Earth Sci. Rev. 2015, 149, 181-202. [CrossRef]

112. Dai, S.; Wang, X.; Seredin, V.V.; Hower, J.C.; Ward, C.R.; O’Keefe, J.M.K.; Huang, W.; Li, T.; Li, X.; Liu, H.; et al. Petrology, mineralogy, and geochemistry of the Ge-rich coal from the Wulantuga Ge ore deposit, Inner Mongolia, China: New data and genetic implications. Int. J. Coal Geol. 2012, 90-91, 72-99. [CrossRef]

113. Dai, S.; Wang, P.; Ward, C.R.; Tang, Y.; Song, X.; Jiang, J.; Hower, J.C.; Li, T.; Seredin, V.V.; Wagner, N.J.; et al. Elemental and mineralogical anomalies in the coal-hosted Ge ore deposit of Lincang, Yunnan, southwestern China: Key role of $\mathrm{N}_{2}-\mathrm{CO}_{2}$-mixed hydrothermal solutions. Int. J. Coal Geol. 2015, 152, 19-46. [CrossRef]

114. Dai, S.; Yang, J.; Ward, C.R.; Hower, J.C.; Liu, H.; Garrison, T.M.; French, D.; O'Keefe, J.M.K. Geochemical and mineralogical evidence for a coal-hosted uranium deposit in the Yili Basin, Xinjiang, Northwestern China. Ore Geol. Rev. 2015, 70,1-30. [CrossRef]

115. Rickard, D. Limiting conditions for synsedimentary sulfide ore formation. Econ. Geol. 1973, 68, 605-617. [CrossRef]

116. Qin, G.; Cao, D.; Wei, Y.; Wang, A.; Liu, J.; Song, S. Geochemistry Characteristics of the Permo-Carboniferous Coals in Fugu Mining district, Ordos Basin, China: Implication of sediment source region, marine environment and groundwater. manuscript in preparation.

(C) 2019 by the authors. Licensee MDPI, Basel, Switzerland. This article is an open access article distributed under the terms and conditions of the Creative Commons Attribution (CC BY) license (http://creativecommons.org/licenses/by/4.0/). 